\title{
Peru: First Review Under the Stand-By Arrangement-Staff Report; Staff Statement Press Release on the Executive Board Discussion; and Statement by the Executive Director for Peru
}

In the context of the first review under the Stand-By Arrangement, the following documents have been released and are included in this package:

- $\quad$ the staff report for the First Review Under the Stand-By Arrangement, prepared by a staff team of the IMF, following discussions that ended on May 15, 2007, the officials of Peru on economic developments and policies. Based on information available at the time of these discussions, the staff report was completed on June 13, 2007. The views expressed in the staff report are those of the staff team and do not necessarily reflect the views of the Executive Board of the IMF;

- $\quad$ a staff statement of June 27, 2007 updating information on recent developments;

- $\quad$ a Press Release summarizing the views of the Executive Board as expressed during its June 27, 2007 discussion of the staff report that completed the review; and

- $\quad$ a statement by the Executive Director for Peru.

The document listed below has been or will be separately released.

Letter of Intent sent to the IMF by the authorities of Peru*

*Also be included in Staff Report

The policy of publication of staff reports and other documents allows for the deletion of market-sensitive information.

To assist the IMF in evaluating the publication policy, reader comments are invited and may be sent by e-mail to publicationpolicy@imf.org.

Copies of this report are available to the public from

International Monetary Fund • Publication Services

$70019^{\text {th }}$ Street, N.W. • Washington, D.C. 20431

Telephone: (202) 623-7430 • Telefax: (202) 623-7201

E-mail: publications@imf.org • Internet: http://www.imf.org

Price: $\$ 18.00$ a copy

\section{International Monetary Fund Washington, D.C.}





\title{
INTERNATIONAL MONETARY FUND
}

\section{PERU}

\section{First Review Under the Stand-By Arrangement}

\author{
Prepared by the Western Hemisphere Department
}

(In collaboration with other departments)

\author{
Approved by Jose Fajgenbaum and G. Russell Kincaid
}

June 13, 2007

- $\quad$ Stand-By Arrangement (SBA). A 25-month SBA for SDR 172.37 million (27 percent of quota) was approved on January 26, 2007. The authorities intend to treat this arrangement as precautionary.

- $\quad$ Performance under the program. All performance criteria for end-March have been observed and all structural benchmarks have been implemented, except the clarification of the tax treatment for financial securitization transactions. The authorities have continued to implement sound macroeconomic policies and reforms toward achieving program objectives.

- Review Issues. The review focused on the implementation of the 2007 program and the policies to: i) to sustain strong fiscal performance and to strengthen the credibility of inflation targeting; ii) enhance the fiscal framework, the effectiveness of the tax system, and the quality of public spending; iii) implement the new plan to enhance the effectiveness of social assistance programs; iv) deepen financial intermediation and reduce dollarization; and v) promote higher sustainable growth.

- Mission. The team comprised M. Cerisola (head), M. Gonzalez, E. Jenkner (all WHD), Messrs. Adedeji (FAD), Breuer (PDR), and Gasha (MCM), visited Lima during May $2-15,2007$. The mission was assisted by Ms. Batini (resident representative).

- $\quad$ Discussions. In Lima, during May 2-15, the mission met with Prime Minister del Castillo, Minister of Finance Carranza, Central Bank President Velarde, Superintendent of Banks Fox, other senior public officials, and representatives from the private sector. The mission liased with the World Bank offices in Lima. Mr. Silva Ruete (OED) participated in some of the meetings. 


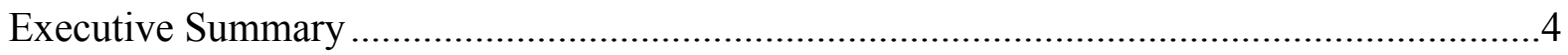

I. Developing and Performance Under the Program ...............................................

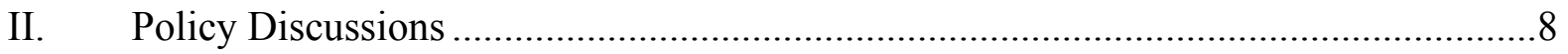

A. Macroeconomic Framework and Risks to the Outlook .................................. 8

B. Fiscal and Poverty Alleviation Issues ............................................................

C. Strengthening the Inflations Targeting Framework .......................................14

D. Strengthening the Resilience and Depth of the Financial System .....................16

E. Other Growth-Enhancing Reforms ...................................................... 17

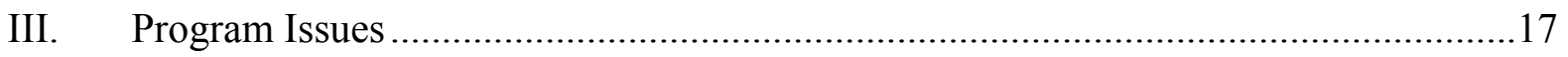

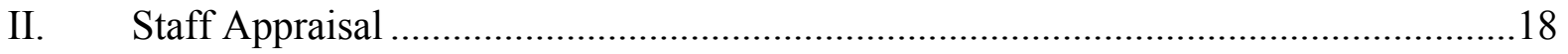

\section{Boxes}

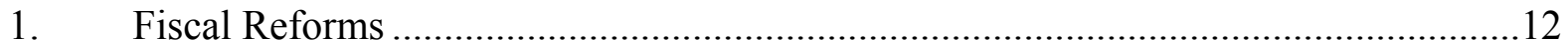

2. Strengthening the Poverty Alleviation Strategy ….............................................13

3. Inflation Developments and Outlook................................................................ 15

Figures

1. Real Sector Developments ...............................................................................20

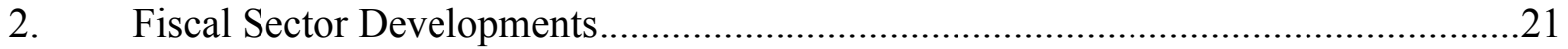

3. External Sector Developments....................................................................22

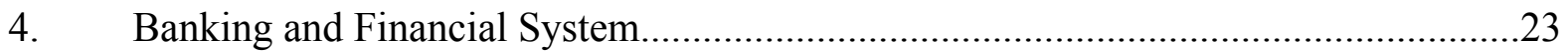

Tables

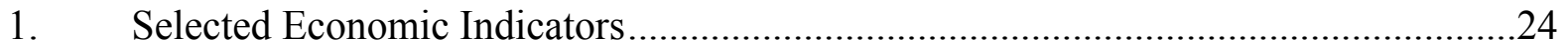

2. Quantitative Performance Criteria and Inflation Consultation Mechanism

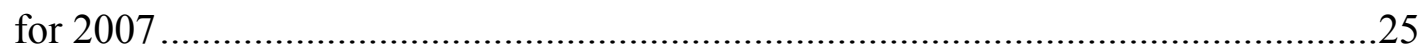

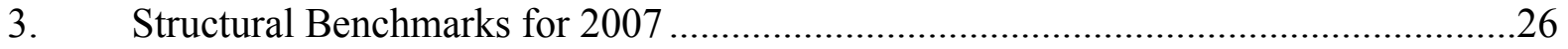

4. Fiscal Operations of the Combined Public Sector ....................................................27

5. Fiscal Operations of the Combined Public Sector .................................................28

6. Financing of the Combined Public Sector ...........................................................29

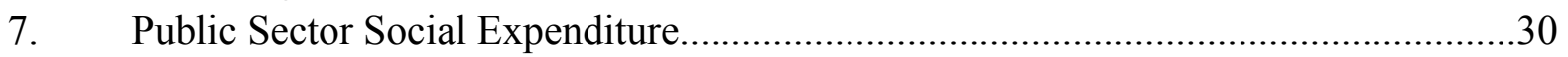

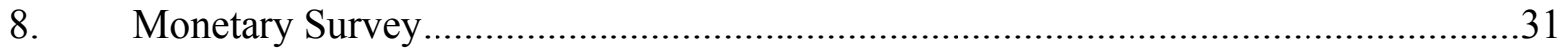

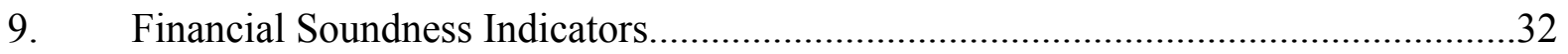

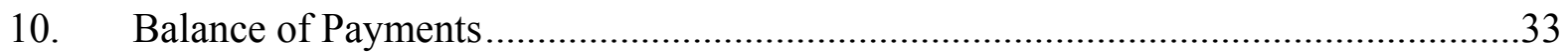




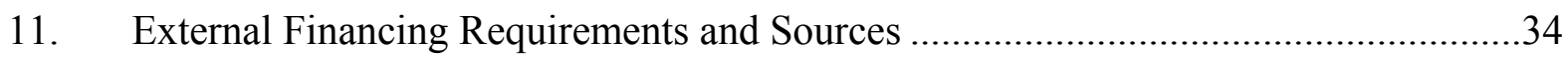

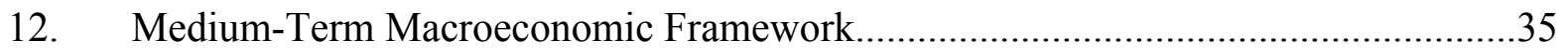

13. Financial and External Vulnerability Indicators ..................................................36

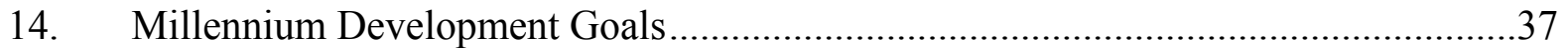

15. Proposed Schedule of Purchases Under the Stand-By Arrangement, 2007-08...........38

16. Capacity to Repay the Fund as of March 29, 2007 ................................................39

\section{Appendix}

I. Debt Sustainability Analysis

\section{Annexes}

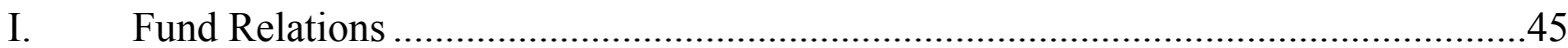

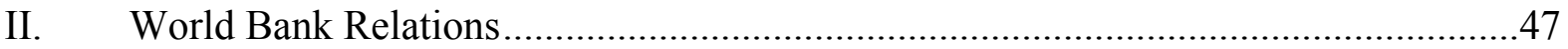

III. Relations with the Inter-American Development Bank .........................................49

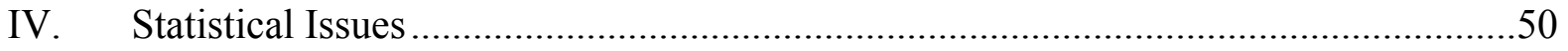




\section{EXECUTIVE SUMMARY}

\section{Background}

The economy is performing remarkably well. Real GDP growth is at record-highs; inflation is well-contained; fiscal prudence continues; external creditworthiness has solidified, and the financial system has strengthened. The program is on track, with significant progress on the structural front.

\section{Key Issues}

Sustaining a strong performance under the program should help Peru secure the benefits of prudent policies and reforms. Implementing sound macroeconomic policies and reforms would reduce vulnerabilities, entrench sustainable growth and reduce poverty, setting the stage for a strong exit from Fund-supported programs and for achieving investment grade.

Outlook and Risks. The economic outlook remains favorable, with risks largely dependent on external conditions, most notably related to commodity prices and global financial conditions.

Policies. The authorities remain committed to:

- $\quad$ Consolidate macroeconomic stability, by maintaining fiscal discipline and reducing vulnerabilities; and by advancing reforms, enhancing the inflation targeting framework, while maintaining an appropriate monetary stance.

- $\quad$ Preserve and improve the quality of public spending, by implementing a sound decentralization of the National System of Public Investment; strengthening the Fiscal Responsibility and Transparency Law; preserving a proper accreditation system for decentralizing spending functions; enhancing existing public financial management systems; and establishing an adequate framework for Private-Public Partnerships.

- Enhance the effectiveness of the tax regime, by streamlining it and broadening the tax base, including through a new framework for tax incentives and exemptions.

- $\quad$ Tackle high poverty levels, by implementing the action plan to enhance the effectiveness of social assistance programs and reforming universal programs.

- $\quad$ Strengthen the financial system, by reducing dollarization, particularly of mortgage loans; improving the regulatory and supervisory framework for public banks, and advancing reforms to deepen domestic capital markets.

- Advance growth-enhancing reforms, by further opening the economy, increasing labor formality and improving the business environment. 


\section{Developments and Performance under the Program}

1. Peru's sound macroeconomic policies are being sustained. The Fund-supported program aims at consolidating macroeconomic stability, improving the quality of spending and the efficiency of the tax regime, tackling high poverty levels, and advancing other reforms in the financial system and the business environment to boost sustainable growth and bring Peru to a higher level of economic and social development.

\section{The economy is performing remarkably well.}

- Real GDP growth is at record-highs. In 2006, growth reached 8 percent - an elevenyear high - supported by very favorable terms of trade, and reflected in a steady rise in private consumption and investment, formal employment levels, and rising confidence (Figure 1). Real GDP grew 71/2 percent (y/y) in the first quarter of 2007.

- Inflation is well-contained. After becoming slightly negative in April 2007, 12-month inflation turned positive, at 0.9 percent in May, as the impact of large increases in food prices during 2006 and other transitory factors have begun to wane. Core inflation has been stable at $1 \frac{1}{2}$ percent and the central bank has kept policy interest rates unchanged since May 2006. In early February 2007, the central bank reduced its inflation target from 2.5 percent

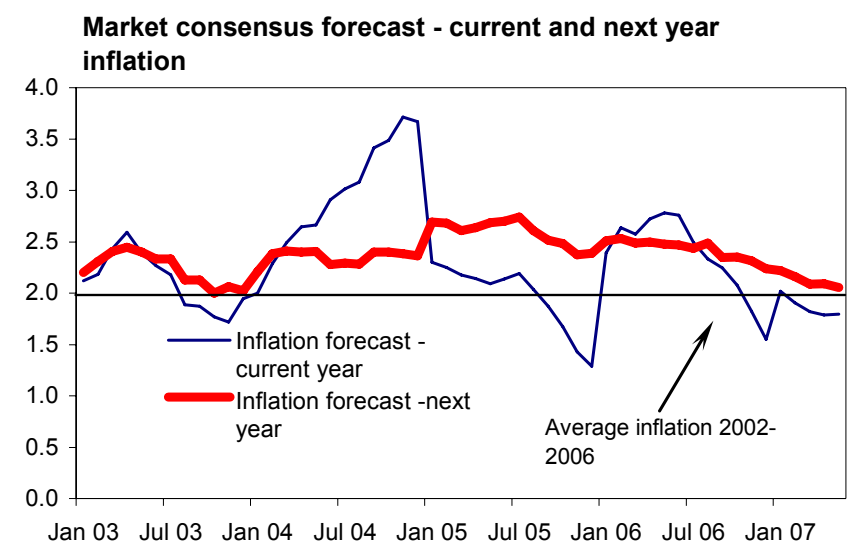
to 2 percent, keeping the tolerance range at $+/-1$ percent. This aligned the target with the inflation expectations and the average inflation rate observed in Peru and its major trading partners since adopting inflation targeting in 2002.

- $\quad$ Fiscal prudence is being preserved. The consolidated public sector posted an overall surplus of 2.2 percent of GDP in 2006 (Figure 2). General government spending rose by about $2 \frac{1}{2}$ percent in real terms, partly reflecting an 8 percent rise in the GDP deflator, which helped bring spending within the 3 percent limit under the Fiscal Responsibility and Transparency Law (FRTL). In the first quarter of 2007, the consolidated government posted a preliminary surplus of 4.9 percent of GDP, well above program targets. The authorities issued two supplementary budgets in February and May for about 1 percent of GDP, to allow for social and infrastructure spending not executed in 2006. 
Fiscal Outcome in 2006 and 2007

\begin{tabular}{lrrrrr}
\hline & \multicolumn{2}{c}{2006} & & 2007 Q1 \\
\cline { 2 - 3 } \cline { 5 - 6 } Combined Public Sector & \multicolumn{2}{c}{$\begin{array}{c}\text { Country } \\
\text { Report 07/54 }\end{array}$} & Prel. & $\begin{array}{c}\text { Country } \\
\text { Report 07/54 }\end{array}$ & Prel. \\
\hline Total revenue & 20.1 & 20.4 & 18.6 & 20.9 \\
Total expenditure & 17.3 & 16.5 & 14.4 & 14.0 \\
Central bank operating balance & 0.1 & 0.2 & & 0.0 & 0.1 \\
Primary balance & 3.0 & 4.1 & & 4.2 & 7.0 \\
Interest payments & 2.0 & 1.9 & & 2.4 & 2.1 \\
Overall balance & 1.0 & 2.2 & & 1.8 & 4.9 \\
\hline
\end{tabular}

Sources: Fund Staff estimates and Peruvian authorities.

- $\quad$ Peru's external creditworthiness has solidified steadily (Figure 3). Fiscal prudence and active debt management have reduced public debt and improved its cost, currency mix, and maturity structure, ${ }^{1}$ leading to credit rating upgrades and record low sovereign bond spreads. ${ }^{2}$ Peru faced limited pressure during the most recent turbulence in global capital markets, and central bank purchases in the foreign exchange

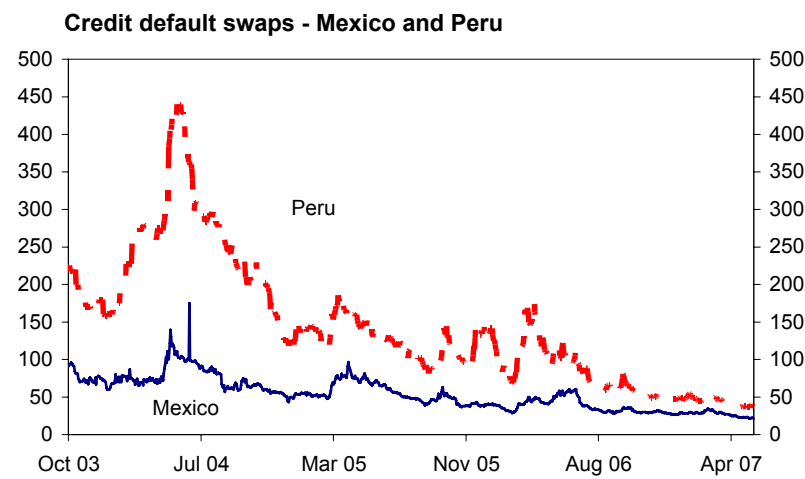
market brought official reserves to about 175 percent of FX deposits as of end-May 2007.

- $\quad$ Financial intermediation has deepened and the system's resilience strengthened. Credit to the private sector increased by around 25 percent over the past 18 months (Figure 4), with sol-denominated credit (led by consumer and mortgage loans)

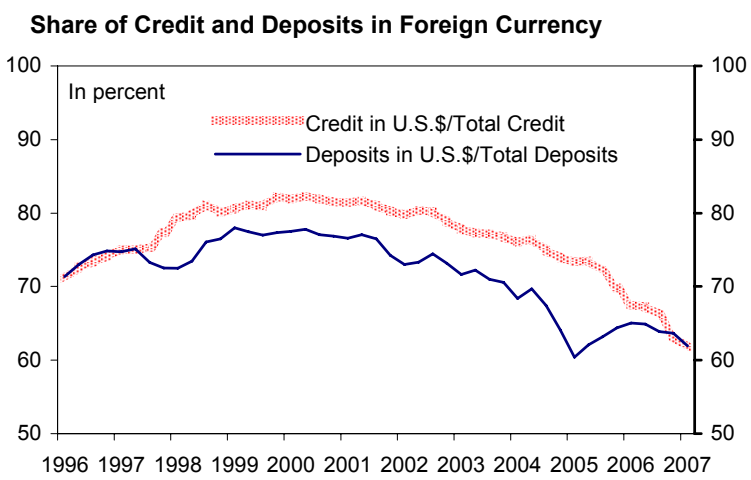

\footnotetext{
${ }^{1}$ In February 2007, the government swapped $\$ 2.3$ billion of external debt, extending the average maturity of public debt from $81 / 2$ years to $91 / 2$ years. In May, the authorities reached agreement to prepay about $\$ 2.5$ billion in Paris Club nonconcessional debt maturing during 2007-15.

${ }^{2}$ Recently, Fitch upgraded the rating outlook to positive, while Moody's placed Peru for a review of its rating. Fitch and Moody's ratings for Peru are one and three notches below investment grade, respectively.
} 
increasing at annual rates of around 30 percent. Dollarization is declining steadily, but remains high. With buoyant growth in corporate profits and high confidence, equity prices have tripled since early 2006 , and price-earnings ratios are at high levels.

Financial Soundness Indicators of the Banking System 1/

\begin{tabular}{lrrr}
\hline & 2005 & 2006 & 2007 \\
\hline Regulatory Capital to Risk Weighted Assets & 12.0 & 12.5 & 12.5 \\
Nonperforming Loans to Total Loans & 2.1 & 1.6 & 1.6 \\
Provisions to: & 235.3 & 251.4 & 246.5 \\
Nonperforming loans & 80.3 & 100.3 & 104.1 \\
$\quad$ Nonperforming, restructured, and refinanced loans & 2.2 & 2.2 & 2.4 \\
Return on Assets & 22.2 & 23.9 & 25.8 \\
Return on Equity & 45.5 & 44.2 & 44.8 \\
Liquid Assets to Total Short Term Liabilities & 23.1 & 17.1 & 30.2 \\
Net Open Position in Foreign Exchange to Capital & & & \\
\hline Source: SBS. & & &
\end{tabular}

3. The program is on track, with significant progress on the structural front. All end-March 2007 performance criteria and structural benchmarks for end-March have been broadly observed (Tables 2 and 3). The tax regime has been simplified and its base broadened, while the tax treatment of financial derivatives has been clarified, except for securitized transactions. A unit to monitor fiscal performance by sub-national governments (SNGs) was established at the Ministry of Finance and a strategy to strengthen the effectiveness of social assistance programs (SAPs) has been published. Progress on a legal framework for PPP operations (an end-June structural benchmark) has been slow, partly reflecting personnel reshuffling.

4. However, recent fiscal measures entail some risks to the program. Two decrees were issued in mid-May to accelerate the approval of public investment projects and concessions until end-2007, by simplifying evaluation procedures under the National System of Public Investment (SNIP). ${ }^{3}$ Moreover, SNGs are also allowed to use canon minero resources - usually earmarked for investment in infrastructure - for hiring teachers temporarily in regions. While the Ministry of Finance retains an important role in approving large sectoral projects and concessions, as well as for those by SNGs that require external borrowing or guarantees, these measures bring some risks to the level and quality of public spending.

\footnotetext{
${ }^{3}$ The decrees also exempt a hydrolelectric public investment project in Alto Piura (about \$700 million) from SNIP procedures.
} 


\section{Policy Discussions}

5. There was broad agreement that sustaining a strong performance under the program would help Peru secure the benefits of prudent policies and reforms.

Discussions centered on how best to use the opportunity provided by favorable economic conditions to consolidate prudent policies and advance reforms to achieve key program goals by:

$>\quad$ Preserving a strong fiscal stance to entrench macroeconomic stabilization and reduce vulnerabilities faster, while ensuring that pressing social and infrastructure needs are addressed.

$>\quad$ Improving the quality of public spending and the effectiveness of the tax system. Implementing the poverty alleviation strategy set out in the recommendations and action plan developed by the Inter-ministerial Committee for Social Affairs (CIAS).

Strengthening the credibility of the inflation targeting framework.

Deepening financial intermediation and reducing dollarization.

\section{A. Macroeconomic Framework and Risks to the Outlook}

6. The economic outlook has remained favorable. Real GDP growth could reach 7 percent in 2007 , above the $5 \frac{1}{2}$ percent envisaged in the program, mainly reflecting higherthan-expected commodity prices. Inflation would return gradually to its target in late 2007 , as the impact of transitory factors wanes and slack in the economy is absorbed. ${ }^{4}$ The external position is expected to remain favorable in 2007, with a current account surplus leading to further accumulation of foreign reserves. Persistently strong commodity prices, along with the expansion of investment projects in most sectors in the economy and improved prospects for the ratification of the Peru-U.S. FTA by the U.S. congress, bring upside risks to the outlook. However, a sharp decline in commodity prices, compounded by increased risk aversion and a severe correction in equity prices, could weigh heavily on the exchange rate and balance sheets in the economy, especially given the still high dollarization. ${ }^{5}$

\footnotetext{
${ }^{4}$ The May consensus forecasts of growth and end-year inflation are 7 percent and 1.8 percent, respectively.

${ }^{5}$ Were terms of trade to return to 2003 levels, the trade and current account surpluses would shift into balance and into a deficit of about 2 percent of GDP, respectively, in 2007-08.
} 
Macroeconomic Framework, 2006-08

\begin{tabular}{|c|c|c|c|c|c|}
\hline & $\begin{array}{c}\text { Country } \\
\text { Report } 07 / 54\end{array}$ & Prel. & \multirow{2}{*}{$\begin{array}{l}\text { Prog. } \\
2007\end{array}$} & \multicolumn{2}{|c|}{ Staff Projection } \\
\hline & 2006 & & & 2007 & 2008 \\
\hline \multicolumn{6}{|c|}{ (Annual percentage change) } \\
\hline Real GDP growth & 6.5 & 8.0 & 5.5 & 7.0 & 6.0 \\
\hline Inflation (end-year) & 1.6 & 1.1 & 2.5 & 2.0 & 2.0 \\
\hline \multicolumn{6}{|c|}{ (In percent of GDP) } \\
\hline External current account balance & 1.3 & 2.6 & 0.2 & 0.9 & 0.5 \\
\hline Public sector balance (excluding CRPAOs) & 1.0 & 2.2 & -0.8 & 0.0 & -0.5 \\
\hline Public sector balance (including CRPAOs) & 0.9 & 2.1 & -1.2 & -0.3 & -0.9 \\
\hline Total public debt (including CRPAOs) & 32.0 & 32.8 & 31.2 & 30.0 & 28.8 \\
\hline \multicolumn{6}{|l|}{ Gross official reserve coverage of: } \\
\hline Short-term debt (residual maturity) & 350 & 357 & 337 & 413 & 458 \\
\hline
\end{tabular}

Source: Fund staff estimates and Peruvian authorities.

\section{B. Fiscal and Poverty Alleviation Issues}

7. The authorities intend to maintain a prudent fiscal stance in 2007. With a more favorable revenue outlook, which staff estimated could exceed program projections by $1 \frac{1}{4}$ percentage points of GDP, the authorities expected that the adjusted deficit target of $1 / 2$ percent of GDP would be met comfortably, in line with the program. The authorities noted that the expected revenue overperformance could also entail a higher-than-programmed level of public spending, partly related to the large mandatory transfers accruing to SNGs, their large canon minero-related deposits in the banking system, as well as recent measures to accelerate spending at all government levels. Nevertheless, they remained confident that program targets would not be compromised and saw scope for the consolidated public sector to overperform and achieve balance in 2007. The authorities and staff agreed that such an outturn would help limit the envisaged large fiscal impulse and assist macroeconomic stability, while helping to reduce public indebtedness further. ${ }^{6}$

\section{The authorities are committed to implementing several reforms to ensure the} high quality of public spending. They explained that measures to accelerate public spending needed to remain consistent with reforms underway to enhance its quality, by implementing:

\footnotetext{
${ }^{6}$ The fiscal impulse would be 2 percent of GDP in 2007, compared to $1 \frac{1}{2}$ percent of GDP previously.
} 
- $\quad$ An effective restructuring of the SNIP. ${ }^{7}$ In late May, the government announced that a high-level commission will prepare a comprehensive reform proposal of the SNIP before end-June, to make it more expeditious while ensuring the high quality of public investment. ${ }^{8}$ In addition, the authorities intend to allocate more resources to bolster SNGs' capacity to assess and execute projects in line with SNIP procedures. Nine regional offices will be established by year-end - in addition to the six already in place - and staffing in these offices will be increased significantly. To further support SNGs' capacity, efforts will be made to continue involving the private sector, following several cooperation agreements signed with universities.

- $\quad$ An adequate use of the canon minero. In response to staff's concerns, the authorities explained that using canon minero resources would allow some SNGs to address temporarily protracted staffing bottlenecks in education, in coordination with the Ministry of Education, with the central government expected to provide financial support in 2008 .

- A comprehensive review of the FRTL. Work continues on how best to balance the need to preserve fiscal discipline with more effective expenditure rules. A supplementary budget approved in May modified the 3-percent real expenditure limit, which now applies to current spending at the central government level, and removed all transfers, providing much needed room for infrastructure spending and strengthening the chances of compliance with expenditure rules. ${ }^{9}$ Maintenance expenditures would not be excluded from the limit until a new budget classification system is established to minimize misclassification risks. With further amendments still being discussed, staff stressed that the introduction of small margins to the limits of 1 percent of GDP for the overall deficit and of 3 percent for growth in real expenditures, respectively - beyond which sanctions would apply, would not help minimize risks arising from factors beyond the authorities' control and undermine credibility. A Fiscal Coordination Committee would be established as originally envisaged.

- Fiscally-sound decentralization. With a unit established at the Ministry of Finance, the monitoring of SNGs — including compliance with the FRTL_-is being

\footnotetext{
${ }^{7}$ Law 28802 decentralized the SNIP in early 2007, providing SNGs with full discretion for viability approval of projects that do not involve external financing or public guarantees.

${ }^{8}$ The commission will be chaired by the Vice Minister of Economy, and include members from other MEF and government agencies, as well as a president of a region chosen by the National Assembly of Regional Governments and the mayor of the city with the largest execution of public investment projects in 2006.

${ }^{9}$ To strengthen the predictability of expenditure and minimize risks of noncompliance with the FRTL, the growth in expenditure in real terms will be calculated using the inflation target of 2 percent.
} 
strengthened. To minimize the fiscal impact of the anticipated devolution of 185 functions to regional governments by end-2007, staff urged the authorities to preserve an adequate accreditation system in place. In transferring the ownership of three electricity companies to regional governments, the authorities intend to ensure that adequate management remains in place to preserve tight budget constraints and governance.

- $\quad$ Public financial management reforms. Five pilot projects on performance budgeting have been initiated, while the results of the audit of the Integrated Financial Management System (SIAF) are expected by September. The authorities intend to expedite and strengthen public procurement procedures. An FAD resident advisor is assisting the authorities in establishing a Treasury Single Account at the central government level by end-2007, in line with the program.

- $\quad$ A legal framework for PPP operations. The authorities intend to finalize the draft legal framework in the next few months, and expect to submit it to congress by endSeptember. The staff stressed the importance that all PPP projects continue to be subject to SNIP evaluation procedures. The authorities would limit the use of CRPAOs to contracts already signed, while continuing to explore alternative methods of financing to improve the risk-sharing balance between private and public sector.

\section{The authorities and staff agreed that the recent tax reforms will enhance the} effectiveness of the tax regime. The authorities were highly satisfied with the quality of the reforms, which reduce distortionary taxes and broaden the tax base (Box 1). Staff commended the authorities for rationalizing tax incentives and replacing exemptions in the Selva region with transfers earmarked for infrastructure. With pressures to grant new exemptions, staff encouraged the authorities to resist them. Efforts by the tax administration agency SUNAT remain focused on upgrading information systems, implementing welltargeted audits, and strengthening cross-checks between domestic taxes and customs.

\section{The staff welcomed the action plan to rationalize and strengthen SAPs.}

Following the merger of 82 SAPs into 26 , the authorities intend to finalize updating the single registry of beneficiaries and the household targeting system, critical for adequately registering beneficiaries. They agreed with staff on the importance of providing the CIAS with a permanent head and technical staff and agreed to make this measure an end-September structural benchmark. This would bolster its effectiveness and ensure the implementation of the anti-poverty plan (Box 2). In light of the success of the

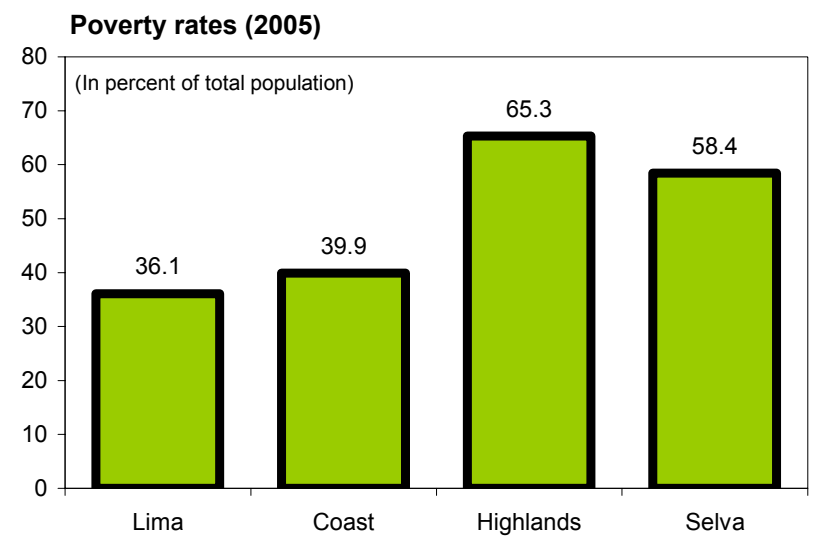


conditional-cash transfer program Juntos in rural areas, the authorities will increase its focus on malnutrition, while enhancing its conditionality. They would also launch a pilot program aimed at reducing child malnutrition in three provinces, following the new comprehensive criteria established by the CIAS. These efforts were also being complemented by the voluntary contributions from mining companies, which were beginning to finance projects in several regions. The authorities acknowledged that the reform of some programs facing large inefficiencies may be politically difficult and agreed on the need to continue building consensus toward reform.

\section{Box 1: Fiscal Reforms}

Since late December, the authorities introduced three packages of fiscal measures aimed at:

\section{Reducing distortionary taxes and increasing tax compliance.}

- $\quad$ The tax rate on net assets (ITAN) was reduced from 0.6 percent to 0.5 and the threshold revised downward from S/. 5 million to S/. 1 million. The exemption of credit services from VAT is now a permanent feature of the tax system (consistent with international practice); the capitalization of interest on outstanding tax debt has been eliminated; and participation in the simplified regime has been extended.

- $\quad$ A timetable for reducing the financial transactions tax has been set, envisaging its gradual decline from 0.08 percent at present, to 0.07 percent in 2008 , and to 0.05 percent by 2010 . The ITAN rate will be reduced further to 0.4 percent by 2009 .

\section{Broadening the tax base.}

- The tax treatment of financial instruments has been clarified, with capital gains and income from financial derivative instruments now taxed. Capital gains from stock trading will be taxed at an effective rate of 5 percent from 2009 on, complemented by a clear definition of the gross base for income tax purposes. The early refund of VAT payments, mainly for the mining and hydrocarbon sectors, has been extended to all sectors, specifically for firms making investments over $\$ 5$ million.

- A new framework for tax incentives introduces time limits (6 years) to the granting of new exemptions, conditioning their renewal (up to 3 years) to an evaluation of whether the goals have been achieved. New exemptions for indirect taxes are also eliminated and congress will have to inform MEF before approving any new tax exemptions. Ministries have 2 years to present an assessment of existing tax exemptions to congress.

- $\quad$ Tax exemptions in the Selva region (except Loreto) are replaced with direct transfers for investment, maintenance of infrastructure and social expenditure. However, the elimination of certain exemptions on the VAT will be gradual. 


\section{Box 2: Strengthening the Poverty Alleviation Strategy}

The CIAS has outlined the criteria and steps for the reform of social assistance programs (SAPs). The reform is centered around "three pillars" for anti-poverty efforts: i) human development, ii) promoting economic opportunities, iii) establishing a social safety net.

\section{A Diagnosis suggests that existing SAPs have:}

- Weak articulation and links to goal-achievement. SAPs are not well integrated and lack focus on achieving goals, leading to undercoverage and important leakages in terms of targeted population.

- Deficiencies in monitoring and assessing their social impact. SAPs lack adequate systems and procedures for identifying beneficiaries, as well as clearly defined exit strategies.

- High administrative costs. About 80 percent of SAPs have administrative costs that exceed 10 percent of the total spending under the program.

\section{The Proposed Reform is based on:}

- Reorganizing and refocusing SAPs to improve synergies. By providing goods and services for specific needs of beneficiaries around the strategic pillars. For example, to achieve "pillar 1", SAPs will comprise programs related to health, education, malnutrition, and housing.

- Institutional strengthening. A Single Beneficiary Registry and Household Focalization System will be developed to avoid duplications and integrate beneficiary registries, building on the one existing under the successful conditional cash transfer program Juntos.

- Drive for Performance. Performance budgeting will be underpinned by the use of indicators to allocate resources based on expected outcomes and for comparing performance with goals. The Ministry of Finance will provide training on performance budgeting and priority will be given to the poorest municipalities to reduce undercoverage and leakages.

\section{The Action Plan}

- Phase I: Targeted Programs. About 82 programs are being streamlined and consolidated into 26 enhanced programs in 13 programmatic areas. Legal decrees to merge the SAPs are being issued and should be completed by end-June.

- Phase II: Universal Programs. The reform of universal programs will begin in the second half of 2007. 


\section{Strengthening the Inflation Targeting Framework}

\section{The central bank is confident that inflation will remain within the target range.}

With 12-month inflation declining below the 0.5 percent inner band in March, a consultation with staff was triggered under the program. The authorities and staff agreed that in light of the temporary decline in inflation, the current stance of monetary policy remained appropriate (Box 3). Nevertheless, a key challenge for monetary policy would be to gauge the point at which monetary conditions would need to be tightened as slack in the economy is absorbed without compromising the inflation target. The authorities and staff agreed that the new inflation target would help entrench price stability and declining dollarization. The inflation consultation mechanism under the program remains unchanged for the rest of 2007 (Table 2).

\section{Plans to build up official reserves further need to be supported by greater} exchange rate flexibility. There was agreement on the need to continue building up reserves, which are reaching levels broadly consistent with risks of high dollarization, to help avoid large swings in the real exchange rate, were the external environment to deteriorate sharply. A gradual but steady appreciation of the Nuevo Sol over the past year has been consistent with improved fundamentals, while helping remove perceptions of "floors" in the market. However, appreciation pressures have intensified markedly in recent months and could prove increasingly difficult to resist, given the intrinsic

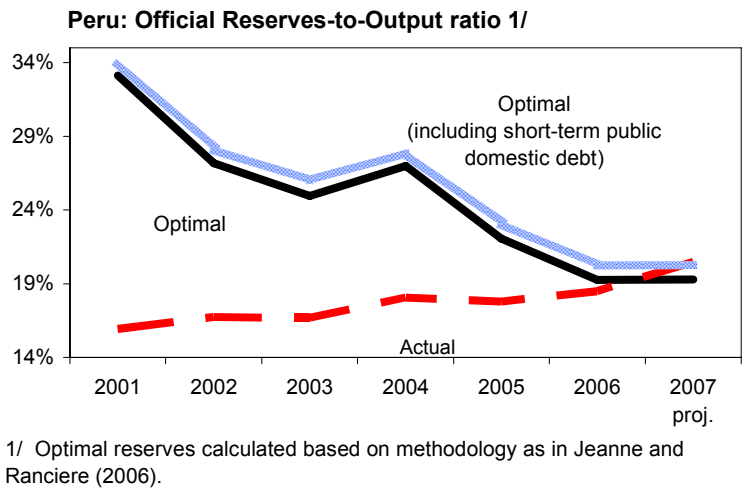
limits to sterilization notwithstanding the support from a strong fiscal position. The staff encouraged the authorities to allow for greater exchange rate flexibility, to avoid one-way bets and promote the use of financial hedges in the economy, building on the increased resilience of the banking system to exchange rate shocks.
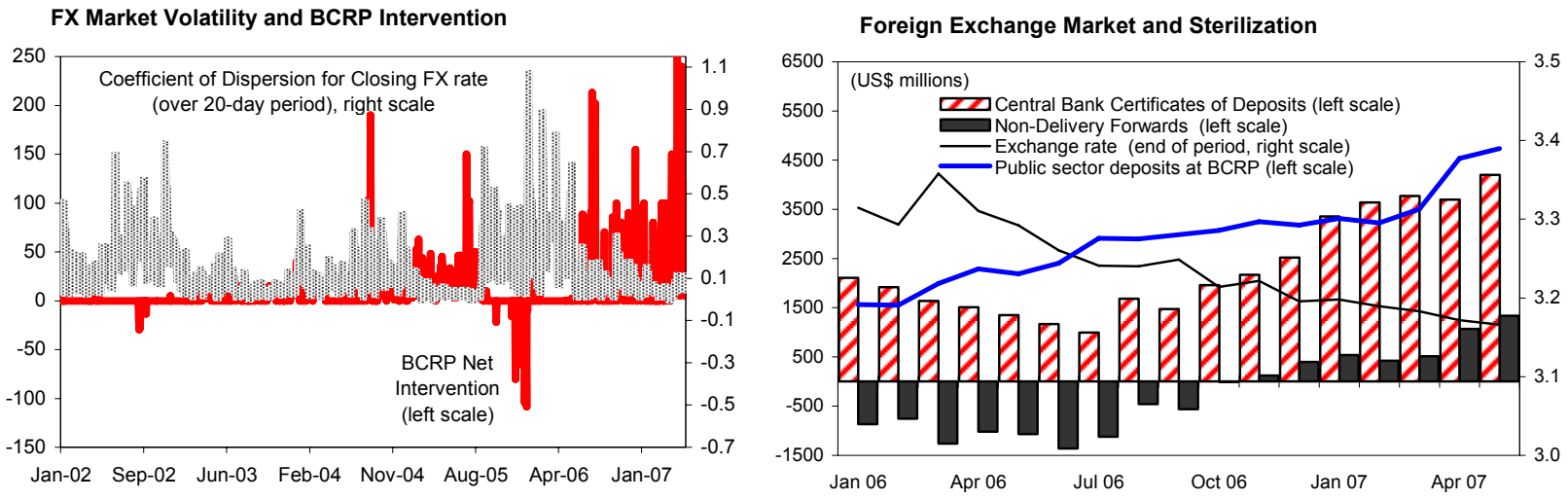


\section{Box 3: Inflation Developments and Outlook}

Inflationary pressures remain subdued. Headline inflation has decelerated, mainly reflecting reductions in the prices of public utilities, fuel, and selected food items. Formal sector wages and capacity utilization levels in the manufacturing sector have risen, but strong productivity gains have reduced unit labor costs, and increased competition appears to have compressed margins. Declining inflation expectations and a gradual exchange rate appreciation have also helped contain pressures from rapid domestic demand growth.
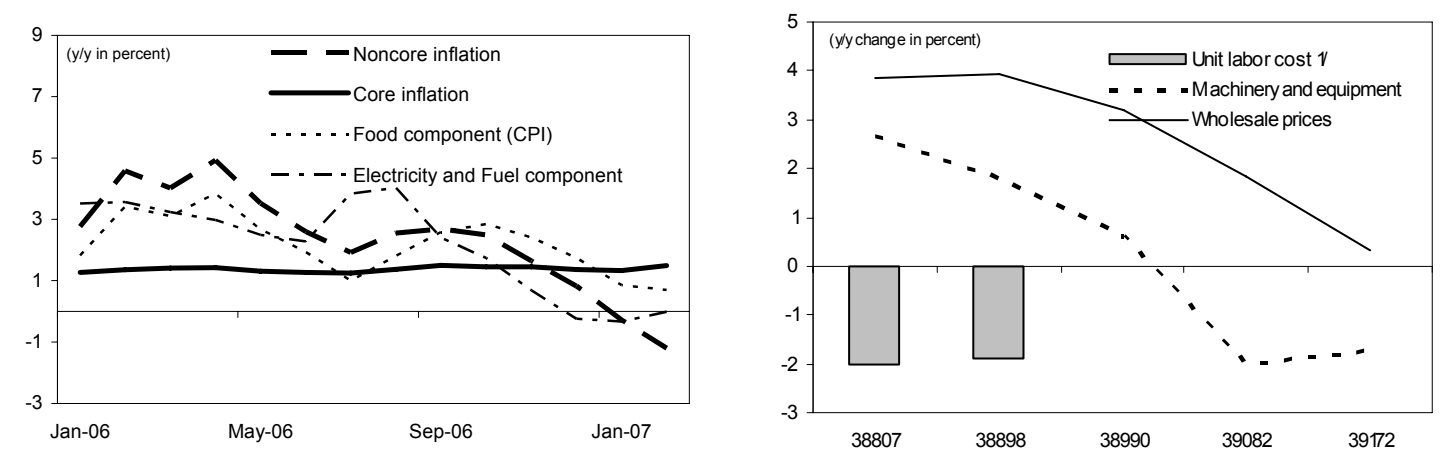

Uncertainty about the extent to which output is close to potential brings risks to the outlook. With a positive output gap of about 1 percent at end-2006, the authorities project 12-month inflation to return to the mid-point of the target range by end-2007. Measuring the level of potential output with a multivariate filter finds less evidence of a positive output gap. A structural model linking monetary policy, output and inflation, suggests that, under these circumstances, inflation could return more gradually toward the target. ${ }^{1 /}$ However, the uncertainty on the output gap, along with a potentially large fiscal impulse, could intensify

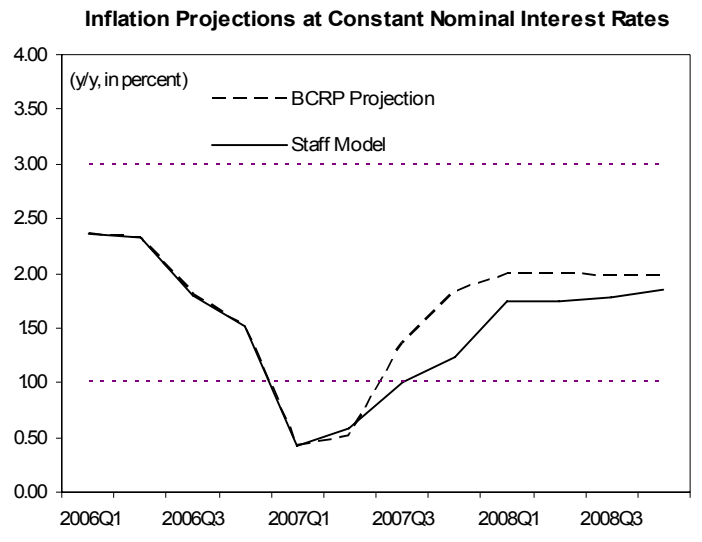
inflation pressures earlier than expected.

1/ See A. Berg, P. Karam and D. Laxton, "A Practical Model-Based Approach to Monetary Policy Analysis-Overview," IMF Working Paper 06/80, for a detailed description of the model. 


\section{Strengthening the Resilience and Depth of the Financial System}

13. Progress in strengthening the financial system continues. The authorities did not see major risks for the financial system from rapid credit growth and rising equity prices. New regulations have been issued requiring banks to constitute special provisions for credits to overexposed customers. Banks' self-assessment of foreign currency portfolios was finished last December, with the required provisioning now constituted and becoming part of the regular supervision process. Prospects for reducing the high dollarization of mortgage loans have strengthened, as large banks have started to extend mortgage loans in

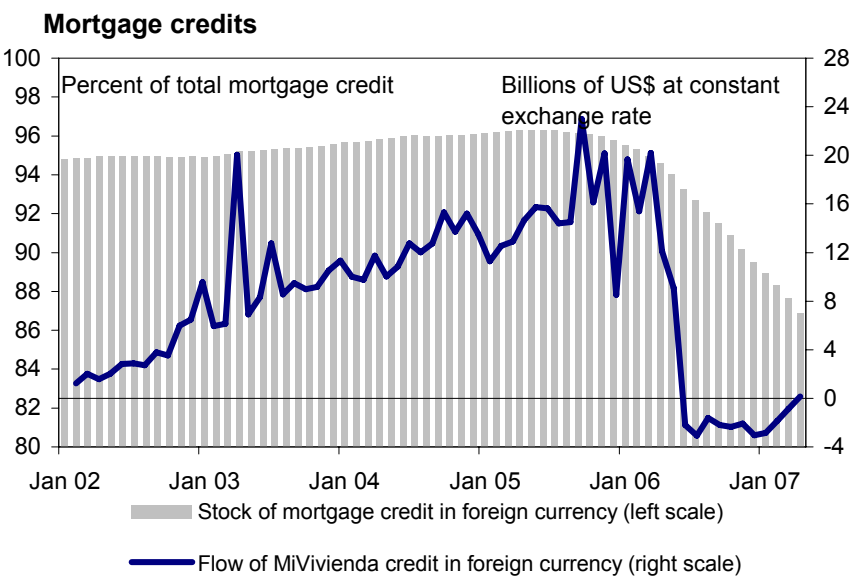
domestic currency with similar terms to those in foreign currency. The authorities are also in the process of exchanging part of MiVivienda's foreign currency portfolio into Nuevo Soles, and new lending programs in domestic currency have been launched. The three publiclyowned financial institutions - COFIDE, Banco de la Nación (BN) and Agrobanco-have begun to better coordinate their credit risk assessments. However, the timing of the approval by congress of draft legislation that would bring these institutions and MiVivienda under the supervisory framework of the Superintendency of Banks is uncertain. The staff encouraged the authorities to closely monitor the rapid growth in BN's consumer lending to ensure that it remains within the 25 percent annual limit.

14. Several reforms continue to deepen domestic capital markets. The limit on pension funds' investments abroad has been raised to 15 percent and the National Stock and Insurance Comission (CONASEV) has established a "fast-track" registration process for public offerings by accredited investors to simplify the issuance of securities. The authorities are assessing market conditions to potentially issue a 30-year sol-denominated bond to further extend the domestic yield curve. They expect that the share of local-currency denominated debt would reach 30 percent by end- 2007 .
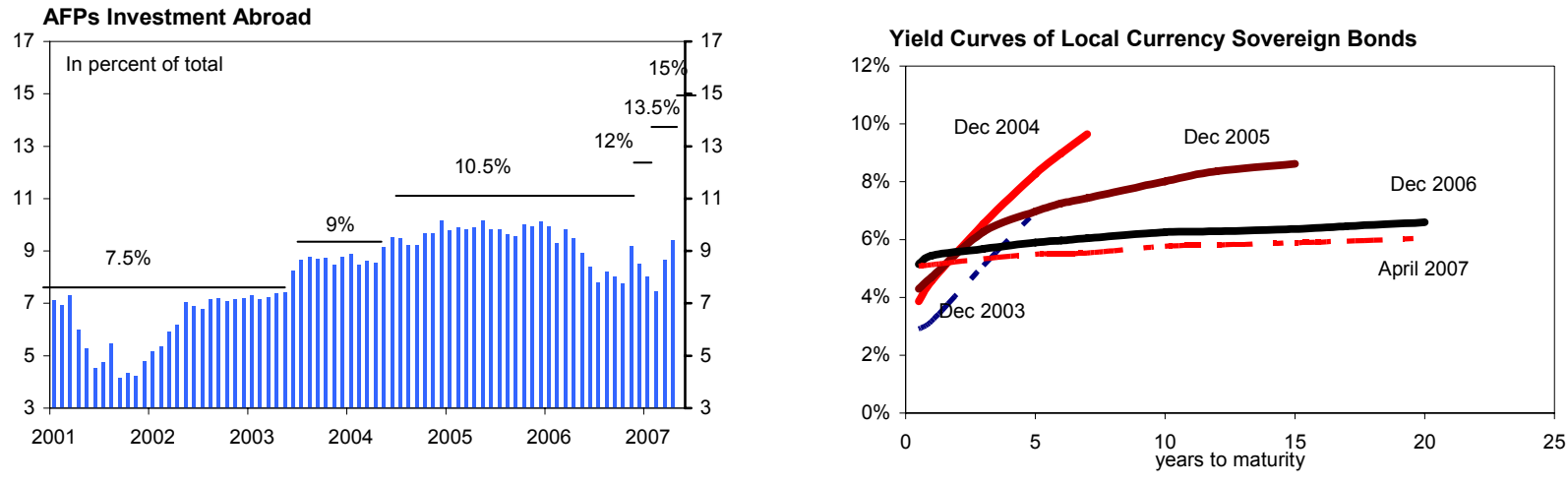


\section{E. Other Growth-Enhancing Reforms}

15. The authorities are confident about the prospects for a prompt ratification of the Peru-U.S. FTA by the U.S. Congress. They explained that several changes would be needed, including on labor and environmental issues, likely to force an amendment and new ratification by Peru's Congress. The authorities did not foresee any difficulties in this regard.

\section{The authorities are assessing options to address labor market informality.} Discussions continue on a comprehensive reform of labor market legislation, which the authorities feel should be balanced with increased access to social benefits. To strengthen the business environment further, the authorities are planning to establish two additional commercial courts in Lima, as well as two more in the regions.

\section{Program Issues}

17. Conditionality. The attached letter of intent reaffirms the authorities' commitment to the program and targets. The indicative targets for September and December are being converted into performance criteria, consistent with the original program. Regarding the structural agenda, a new end-September 2007 benchmark (the appointment of a new permanent head and technical staff of the CIAS) has been added. The full clarification of the tax treatment of financial securitization transactions will be a benchmark for end-December 2007, while the submission of a legal framework for PPP operations will be a benchmark for end-September 2007.

18. Safeguards assessment. An off-site safeguards assessment concluded that there are no significant weaknesses in the Central Bank's safeguards framework. A few measures were proposed to address minor weaknesses related to the duration of the appointment of the external auditor and the terms of the Organic Law on recording unrealized revaluation gains.

19. Paris Club debt. In a recent meeting of the Secretariat, two official creditors indicated the existence of about $\$ 7.5$ million in claims that needed to be reconciled. They did not foresee this standing in the way of the proposed debt repayment operation. The authorities are engaged in reconciling and resolving these disputed claims.

20. Staff discussed with the authorities their views on an exit strategy from Fundsupported programs. The authorities noted that strong performance under the program, along with institutional strengthening, should help reduce vulnerabilities and cement policy credibility. They noted that this should help Peru reach investment grade status and provide a natural exit from Fund-supported programs. 


\section{Staff APpraisal}

21. Peru faces a good opportunity to entrench the benefits of prudent policies and ensure greater equity and poverty alleviation. The economy enjoys the most favorable conditions of the last two decades, with broad-based and record-high growth, low inflation, and rising formal employment. Preserving sound macroeconomic policies and advancing reforms would help reduce vulnerabilities further, entrench sustainable growth and reduce high poverty levels. This will ensure steady progress toward achieving the government's goal of investment grade and help Peru reach a new level of economic and social development.

22. The authorities are appropriately focused on achieving the program's goals.

Staff commends the authorities for the strong implementation of policies and reforms and for their intention to press ahead with a comprehensive agenda to address long-standing structural weaknesses in the fiscal and financial sectors and to reduce poverty.

\section{The reform of the social assistance programs is an important step toward} reducing high poverty. Timely implementation of the strategy to enhance the effectiveness of social assistance programs, including by bolstering the capacity of the CIAS and advancing reforms on large programs facing inefficiencies, are critical steps to begin reducing poverty effectively. The staff encourages the authorities to continue building consensus toward their reform.

\section{The authorities' commitment to maintaining a prudent fiscal strategy is pivotal}

to the program's success. In light of the significant social and infrastructure needs, staff supports the authorities' decision to meet program targets, while welcoming efforts to preserve the quality of public spending. Continued fiscal prudence, including by saving part of any revenue overperformance, should also help keep public debt on a downward trend and assist macroeconomic stability.

25. The authorities intend to preserve the credibility of the fiscal framework. The proposed amendments to strengthen the FRTL by introducing strict sanctions for noncompliance are welcome; however, it will be important that these amendments are implemented consistently, to preserve the credibility and clarity of the FRTL. In addition, the potential inclusion of margins on the limits to the deficit and growth on real current spending should be resisted as it could undermine the hard-won credibility of fiscal policy. In this context, plans to redefine the limit to real expenditure growth seem appropriate. A prompt implementation of the new budget classification, along with improvements in public procurement, should help minimize risks associated with the misclassification of maintenance and infrastructure outlays and help preserve the quality of public spending. It is also crucial that the devolution of spending functions to subnational governments by yearend is consistent with sound accreditation criteria and does not undermine fiscal soundness.

\section{The staff commends the authorities for the recent reforms to strengthen the tax} system. A clear timetable for reducing taxes on financial transactions and net assets has been 
established, while the tax treatment of financial derivatives has been clarified. The new framework rationalizing tax incentives and the required assessment of existing exemptions are commendable and should help solidify Peru's tax structure. Staff encourages the authorities to resist pressures for new exemptions. Adopting performance indicators and more focused audits would assist in sustaining the significant tax administration gains of recent years.

\section{Well-designed public investment policies would help minimize fiscal risks and} support sustainable economic growth and poverty alleviation. The recently announced temporary measures to expedite needed public investment must be balanced by sound procedures to ensure their high quality. It is essential that the decentralization process of the SNIP is improved, to retain a hard-won but more effective framework to assess the viability of public investment projects. For this, increased capacity-building efforts at the SNG level, project monitoring and ex-post evaluation are essential. It is also essential to redouble efforts to establish a comprehensive legal framework for PPPs and to continue exploring alternative financing instruments for PPP projects to ensure a balanced risk-sharing between the public and private sectors.

28. Greater exchange rate flexibility would help solidify the new inflation target and help entrench declining dollarization. To help internalize risks and further anchor expectations, the staff sees scope for greater exchange rate two-way flexibility, given the improved resilience of the banking system to exchange rate shocks, official reserves approaching more desirable levels, and the new inflation target. These efforts should be complemented by measures to reduce the dollarization of mortgage loans. Staff also supports the current stance of monetary policy and encourages continued close monitoring of underlying inflation pressures.

\section{Staff encourages the authorities to sustain efforts in enacting legislation that} would effectively strengthen the regulatory oversight of public financial institutions. The authorities should ensure the effective operation of the newly established committee of representatives of COFIDE, BN and Agrobanco to coordinate their overall credit assessment and lending to private financial institutions. It will also be important to continue monitoring Banco Nacion's recent expansion of consumer lending. Staff also welcomes the reforms to deepen domestic capital markets and encourages the authorities to further streamline the process of registration of securities by CONASEV.

30. The staff supports the completion of the first review under the SBA. In light of the authorities' strong commitment to the program, and good performance, the staff supports the completion of the first SBA review. 
Figure 1. Peru: Real Sector Developments

Investment and consumption have accelerated...

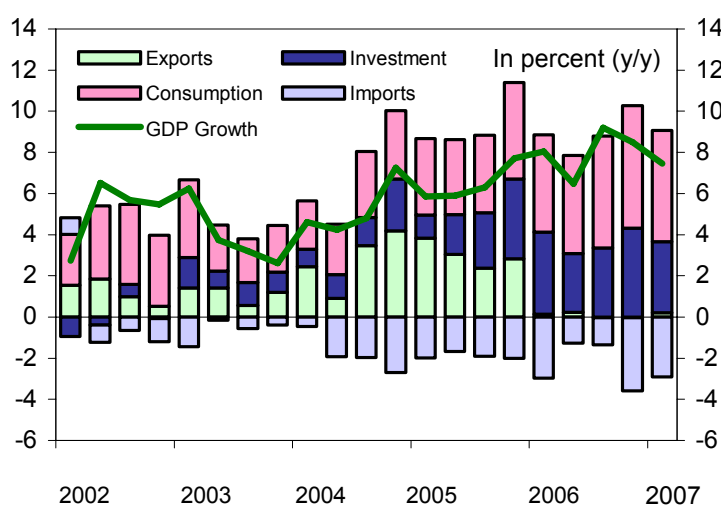

...with both consumer and business confidence rising...

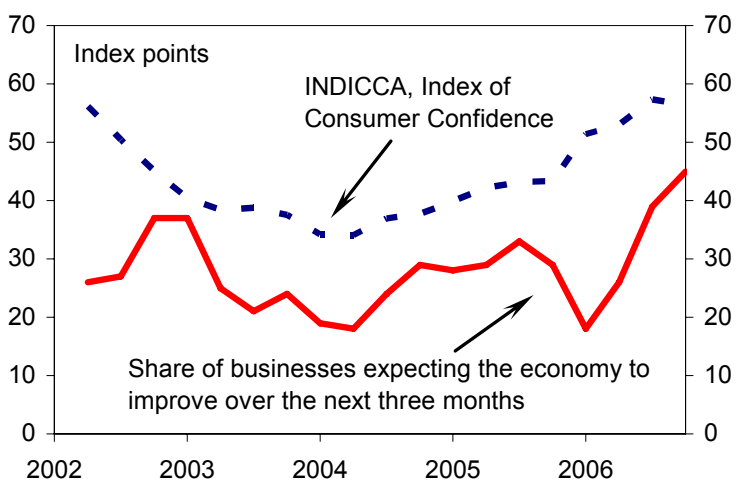

Price pressures remain subdued...
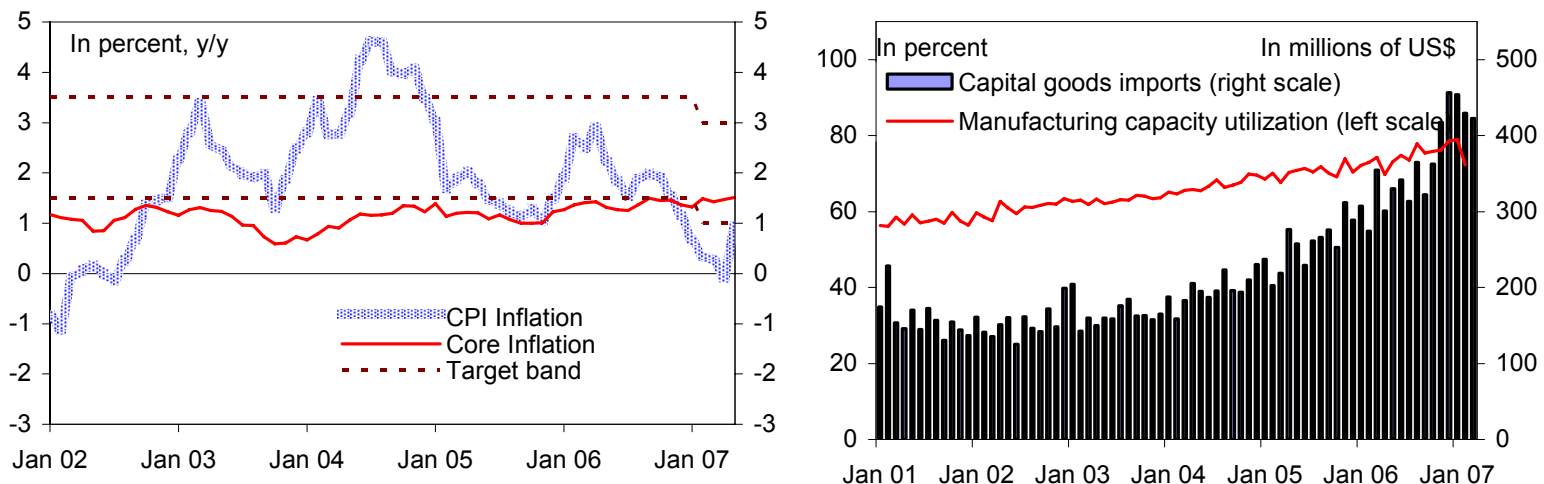

...and economic growth broadened...

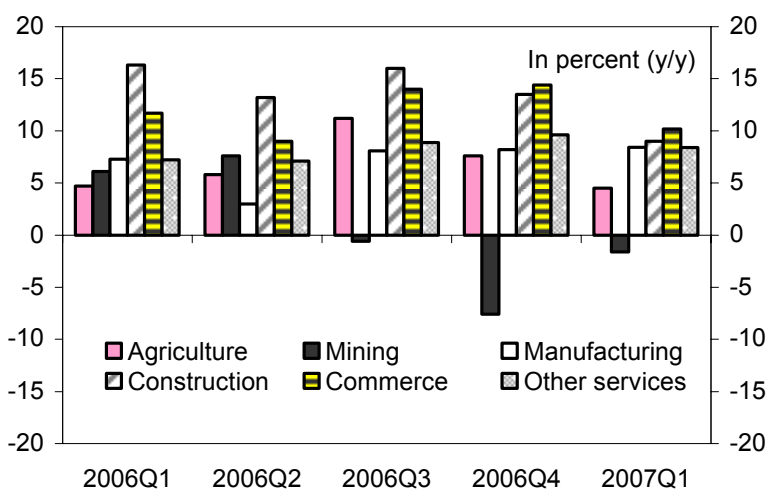

...and formal employment expanding.

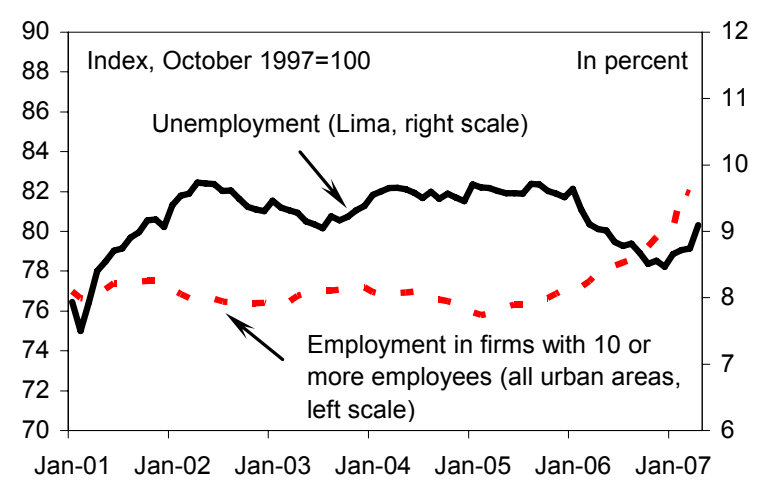

...as high capital investment coincides with a steady but gradual rise in capacity utilization. 
Figure 2. Peru: Fiscal Sector Developments

There has been a sharp improvement in the fiscal balance... ...supported by increased revenue collection.

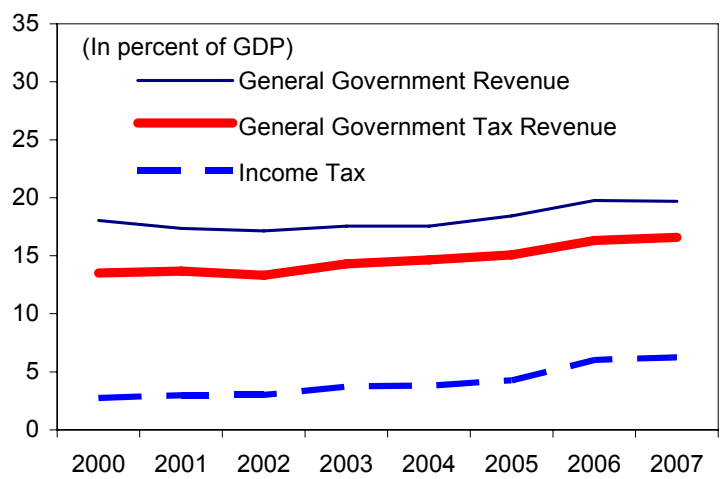

While poised for recovery, the share of expenditure to GDP has declined...

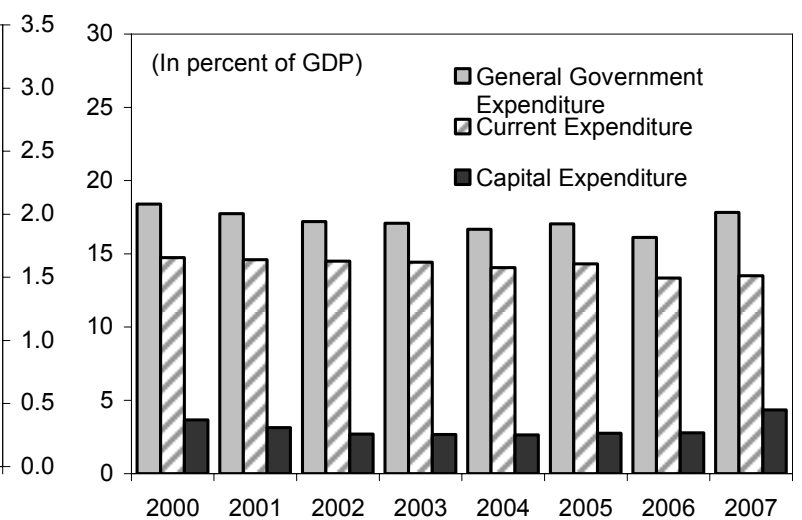

The strong fiscal performance has allowed public debt to decline markedly.

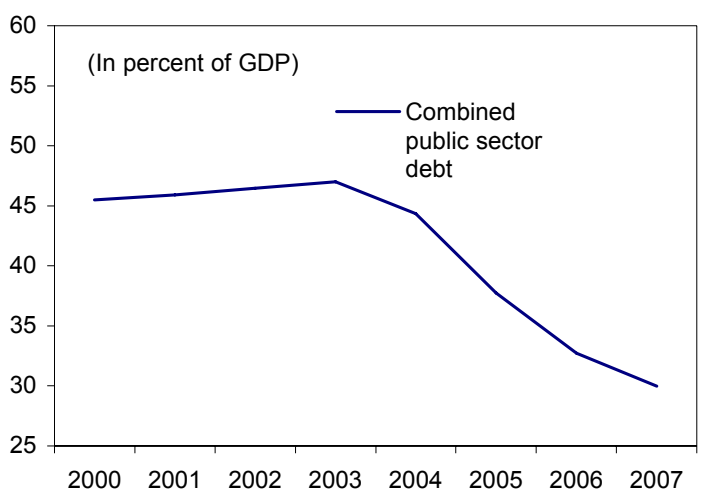

Sources: Central Reserve Bank of Peru; Ministry of Economy and Finance and IMF staff Estimates 
Figure 3. Peru: External Sector Developments

The strong balance of payments is boosted by improved terms of trade...

...and increasing non-traditional exports...

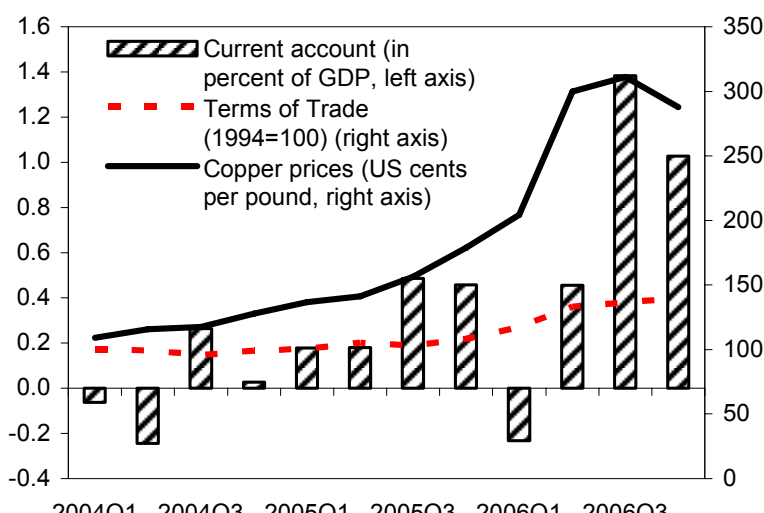

2004Q1 2004Q3 2005Q1 2005Q3 2006Q1 2006Q3

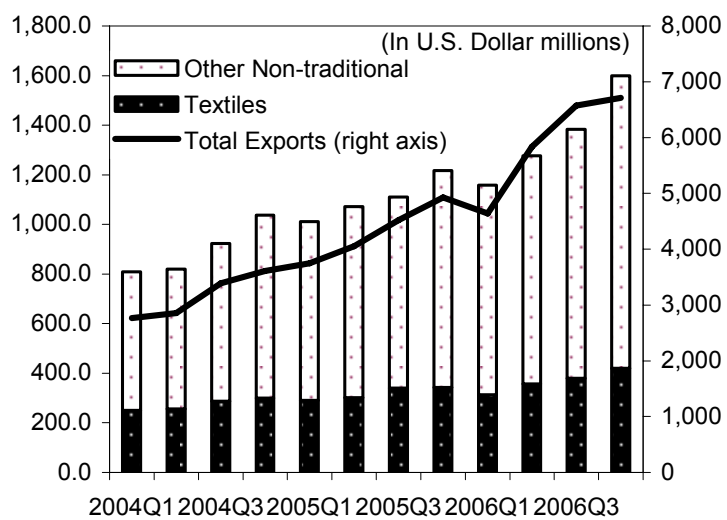

This has helped to build reserves.

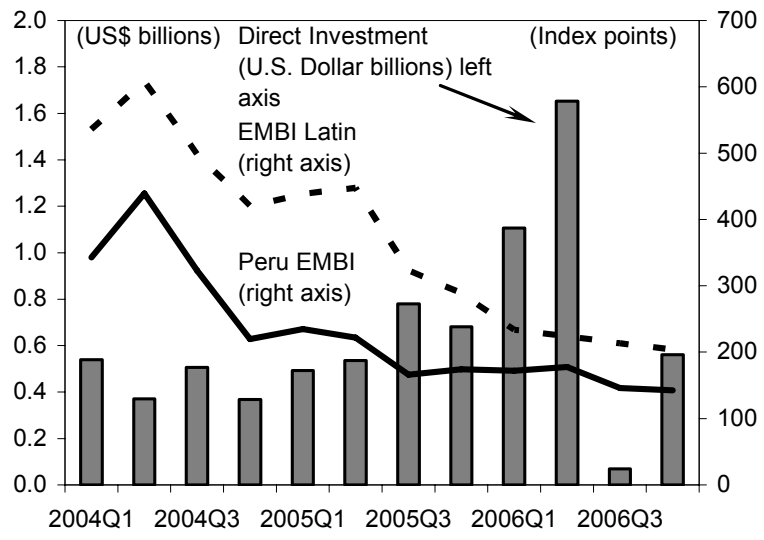

External Debt has declined...

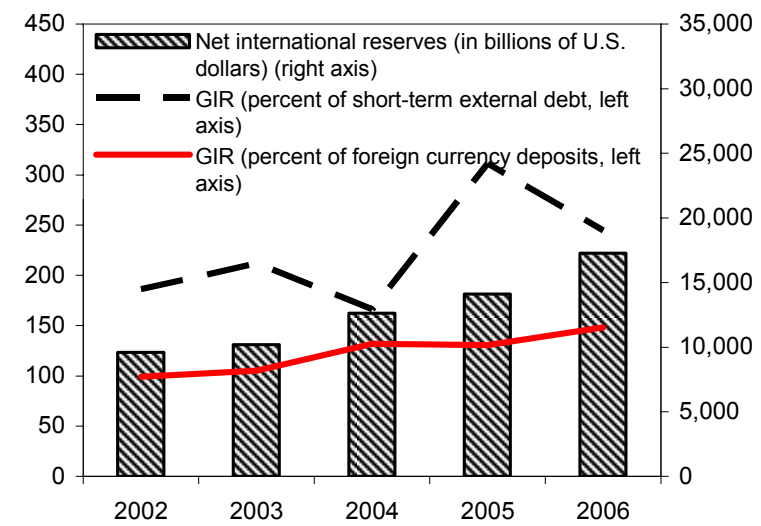

...while the domestic currency share in public debt is rising.
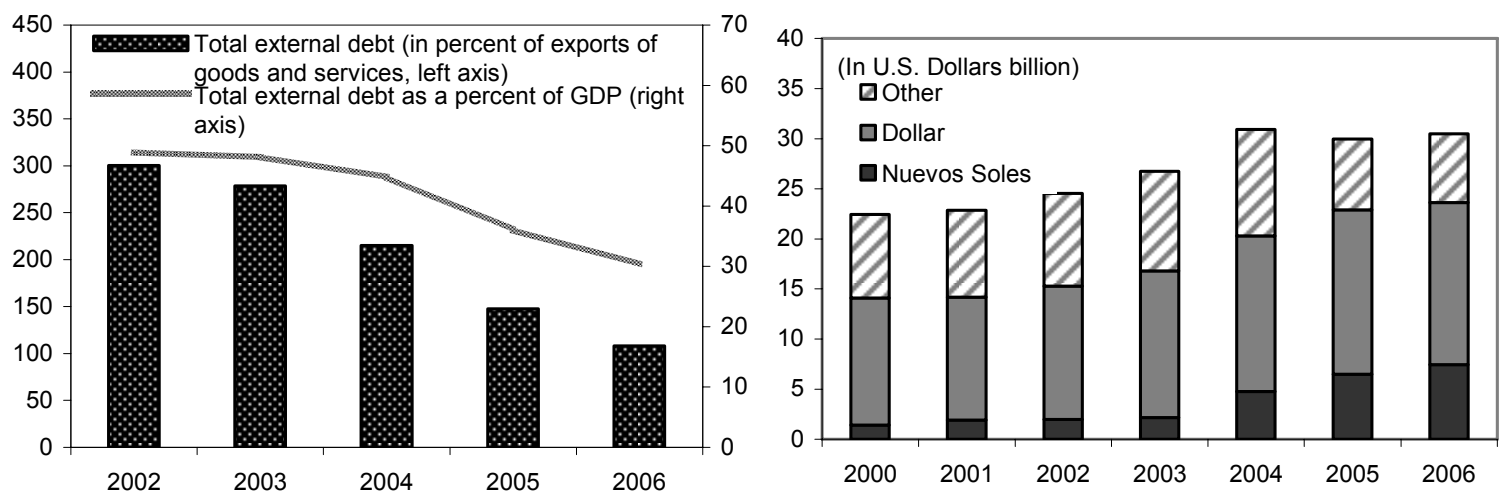

Source: Banco Central de Reserva del Peru, Ministry of Finance, JP Morgan and IMF staff estimates. 
Figure 4. Peru: Banking and Financial System 1/

The banking system remains sound, with strong capitalization ratios and declining non-performing loans...

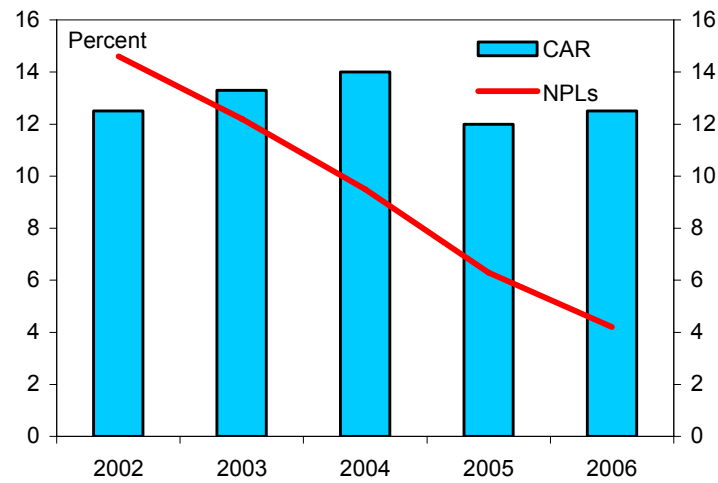

However, the system remains highly dollarized, particularly mortgage loans...

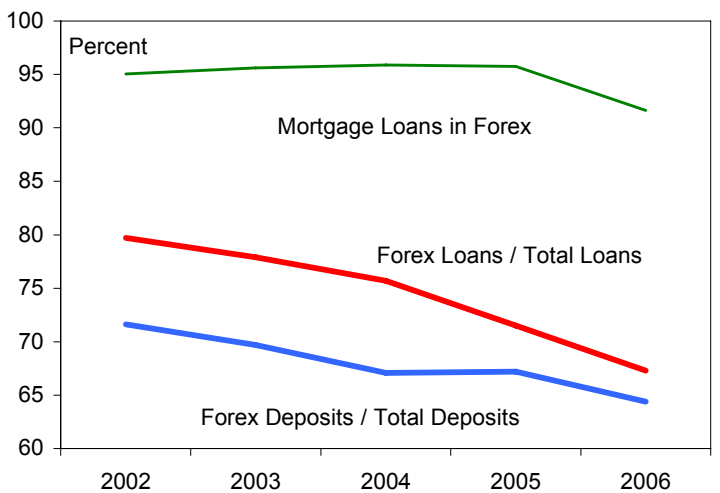

Equity prices have risen sharply, although price/earnings ratios have increased moderately.

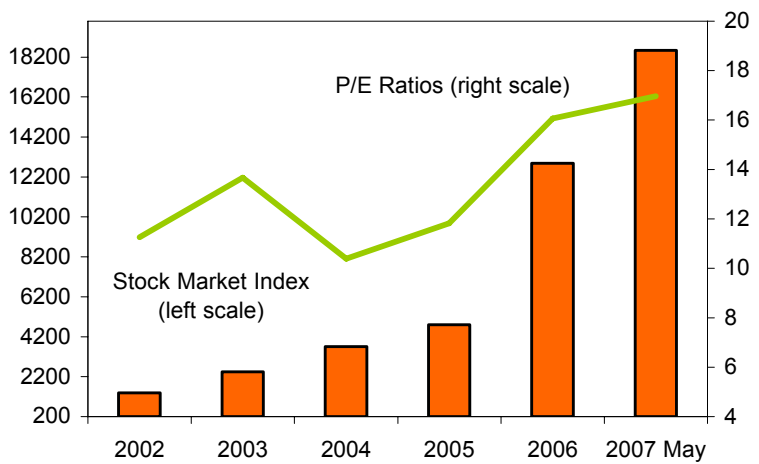

....increasing profitability, and comfortable levels of liquidity and foreign exchange positions.

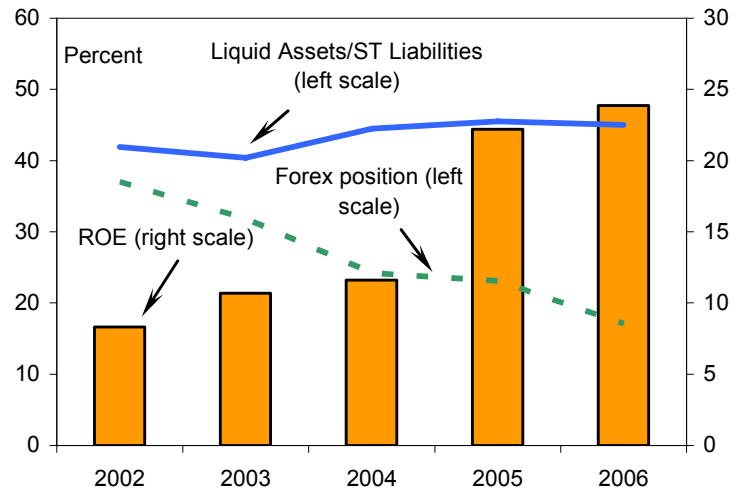

...and financial deepening remains quite low, despite high rates of credit growth in recent years.

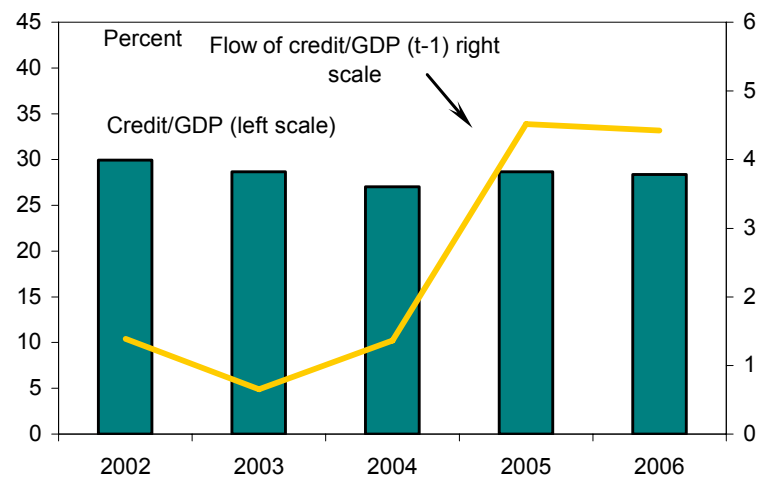

However, capital markets remain relatively small.

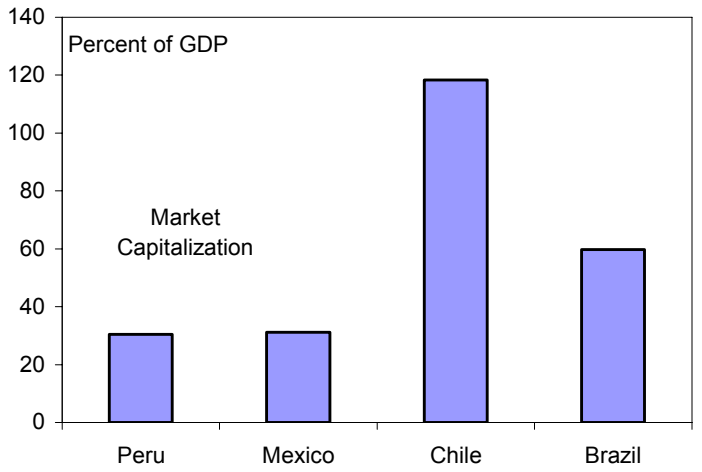

Source: Bloomberg, SBS, World Federation of Exchange Rates and Fund staff estimates.

1/ Banking sector data corresponds to December 2006. 
Table 1. Peru: Selected Economic Indicators

\begin{tabular}{|c|c|c|c|c|c|c|c|}
\hline & \multirow[b]{2}{*}{2003} & \multirow[b]{2}{*}{2004} & \multirow[b]{2}{*}{2005} & \multirow{2}{*}{$\begin{array}{l}\text { Prel. } \\
2006\end{array}$} & \multirow{2}{*}{$\begin{array}{l}\text { Prog. } \\
2007\end{array}$} & \multicolumn{2}{|c|}{ Projection } \\
\hline & & & & & & 2007 & 2008 \\
\hline \multicolumn{8}{|l|}{ Social Indicators } \\
\hline Life expectancy at birth (years) & 70.0 & $\ldots$ & $\ldots$ & $\ldots$ & $\ldots$ & $\ldots$ & $\ldots$ \\
\hline Infant mortality (per thousand live births) & 26.0 & $\ldots$ & $\ldots$ & $\ldots$ & $\ldots$ & $\ldots$ & $\ldots$ \\
\hline Adult literacy rate & 87.7 & 87.8 & $\ldots$ & $\ldots$ & $\ldots$ & $\ldots$ & $\ldots$ \\
\hline Poverty rate (Total) $1 /$ & 52.2 & 51.6 & 50.6 & $\ldots$ & $\ldots$ & $\ldots$ & $\ldots$ \\
\hline Unemployment rate & 9.4 & 9.4 & 9.6 & 8.6 & $\ldots$ & $\ldots$ & $\ldots$ \\
\hline \multicolumn{8}{|c|}{ (Annual percentage change; unless otherwise indicated) } \\
\hline \multicolumn{8}{|l|}{ Production and prices } \\
\hline Real GDP & 3.9 & 5.2 & 6.4 & 8.0 & 5.5 & 7.0 & 6.0 \\
\hline Real domestic demand & 3.4 & 4.4 & 5.5 & 10.6 & 6.2 & 9.2 & 6.5 \\
\hline Consumer Prices (end of period) & 2.5 & 3.5 & 1.5 & 1.1 & 2.5 & 2.0 & 2.0 \\
\hline Consumer Prices (period average) & 2.3 & 3.7 & 1.6 & 2.0 & 2.0 & 1.1 & 2.0 \\
\hline \multicolumn{8}{|l|}{ External sector } \\
\hline Exports & 17.8 & 38.8 & 36.7 & 37.7 & 6.2 & 9.4 & -1.0 \\
\hline Imports & 11.2 & 19.0 & 23.0 & 23.3 & 16.1 & 20.2 & 12.7 \\
\hline Terms of trade (deterioration -) & 1.3 & 9.2 & 5.9 & 26.1 & -5.3 & -0.6 & -10.5 \\
\hline Real effective exchange rate (depreciation -) 2/ & 3.8 & 1.6 & 0.5 & 1.3 & $\cdots$ & $\cdots$ & $\cdots$ \\
\hline \multicolumn{8}{|l|}{ Money and credit $3 / 4$ / } \\
\hline Liabilities to the private sector & 2.5 & 8.5 & 13.5 & 12.3 & 9.3 & 13.8 & 9.6 \\
\hline Net credit to the private sector & -2.9 & 0.3 & 10.0 & 10.6 & 8.0 & 11.6 & 9.4 \\
\hline \multicolumn{8}{|c|}{ (In percent of GDP; unless otherwise indicated) } \\
\hline \multicolumn{8}{|l|}{ Public sector } \\
\hline General government current revenue & 17.4 & 17.5 & 18.3 & 19.6 & 18.5 & 19.6 & 19.1 \\
\hline General government noninterest expenditure & 17.1 & 16.7 & 17.0 & 16.1 & 17.4 & 17.8 & 17.9 \\
\hline Combined public sector primary balance & 0.5 & 1.0 & 1.6 & 4.1 & 1.3 & 1.9 & 1.2 \\
\hline Interest due & 2.2 & 2.0 & 1.9 & 1.9 & 2.0 & 1.8 & 1.7 \\
\hline Combined public sector overall balance & -1.7 & -1.1 & -0.3 & 2.2 & -0.8 & 0.0 & -0.5 \\
\hline \multicolumn{8}{|l|}{ External Sector } \\
\hline External current account balance & -1.5 & 0.0 & 1.3 & 2.6 & 0.2 & 0.9 & 0.5 \\
\hline \multicolumn{8}{|l|}{ Gross reserves } \\
\hline In millions of U.S. dollars $5 /$ & 10,206 & 12,649 & 14,120 & 17,329 & 16,765 & 21,329 & 21,829 \\
\hline Percent of short-term external debt $6 /$ & 211.9 & 166.3 & 311.4 & 356.6 & 336.9 & 412.6 & 458.3 \\
\hline Percent of foreign currency deposits at banks & 105.2 & 131.9 & 130.6 & 148.2 & 139.6 & 167.0 & 165.2 \\
\hline \multicolumn{8}{|l|}{ Debt } \\
\hline Total external debt & 48.1 & 44.9 & 36.1 & 30.3 & 28.4 & 28.1 & 26.5 \\
\hline Combined public sector debt (including CRPAOs) & 47.0 & 44.4 & 37.7 & 32.7 & 31.2 & 30.0 & 28.8 \\
\hline Domestic & 10.0 & 9.2 & 9.7 & 9.2 & 8.1 & 8.7 & 9.2 \\
\hline External $7 /$ & 37.0 & 35.1 & 28.1 & 23.5 & 23.1 & 21.3 & 19.6 \\
\hline \multicolumn{8}{|l|}{ Savings and investment } \\
\hline Gross domestic investment & 18.8 & 18.9 & 18.6 & 21.0 & 21.2 & 22.5 & 24.3 \\
\hline Public sector $8 /$ & 2.8 & 2.8 & 2.9 & 2.8 & 4.3 & 4.8 & 5.2 \\
\hline Private sector & 15.0 & 15.2 & 16.0 & 16.8 & 16.9 & 18.0 & 18.8 \\
\hline Inventories changes & 1.0 & 1.0 & -0.2 & 1.3 & 0.0 & -0.3 & 0.4 \\
\hline National savings & 17.2 & 18.9 & 19.9 & 23.6 & 21.4 & 23.4 & 24.8 \\
\hline Public sector $9 /$ & 1.2 & 1.7 & 2.6 & 5.0 & 3.3 & 4.6 & 4.4 \\
\hline Private sector & 16.0 & 17.2 & 17.3 & 18.6 & 18.1 & 18.7 & 20.4 \\
\hline External savings & 1.5 & 0.0 & -1.3 & -2.6 & -0.2 & -0.9 & -0.5 \\
\hline \multicolumn{8}{|l|}{ Memorandum items: } \\
\hline Nominal GDP (S/. billions) & 213.9 & 237.8 & 261.6 & 305.8 & 317.9 & 329.2 & 349.0 \\
\hline GDP per capita (in US\$) & 2,330 & 2,599 & 2,917 & 3,379 & 3,496 & 3,672 & 3,834 \\
\hline
\end{tabular}

Sources: Central Reserve Bank of Peru; Ministry of Economy and Finance; ECLAC 2002-03; National Statistical Institute (INEI); and Fund staff estimates/projections.

$1 /$ Defined as the percentage of households with total spending below the cost of a basic consumption basket. Figure for 2005 is preliminary.

2/ Based on Information Notice System.

3/ Corresponds to the banking system.

4/ Foreign currency stocks are valued at program exchange rate.

5/ Gross international reserves exceed net international reserves by the stock of Fund credit outstanding.

6/ Short-term debt is defined on a residual maturity basis, and includes amortization of medium- and long-term debt.

7/ Includes debt by the Central Reserve Bank of Peru.

8/ Includes CRPAOs.

9/ Excludes privatization receipts. 
Table 2. Peru: Quantitative Performance Criteria and Inflation Consultation Mechanism for 2007

\begin{tabular}{|c|c|c|c|c|}
\hline & Mar. 31 & Jun. 30 & Sept. 30 & Dec. 31 \\
\hline \multicolumn{5}{|c|}{ (Cumulative amounts from December 31, 2006, millions of New Soles) } \\
\hline \multicolumn{5}{|c|}{ Borrowing requirement of the combined public sector } \\
\hline Unadjusted limits $1 / 2 / 3 / 4$ / & $-1,396$ & $-4,190$ & $-2,761$ & 2,418 \\
\hline Adjusted limits & $-1,646$ & & & \\
\hline Actual & $-4,252$ & & & \\
\hline Margin & 2,606 & & & \\
\hline
\end{tabular}

(Cumulative amounts from December 31, 2006, millions of U.S. dollars)

Net international reserves of the Central Reserve Bank

excluding foreign-currency deposits of financial institutions

Unadjusted targets $5 / 6$ /

Adjusted targets

Actual

$-260$

$-635$

948

Margin

Outstanding short-term external debt of the nonfinancial

public sector

Limits

Actual

Margin

Contracting or guaranteeing of nonconcessional public

debt with maturity of at least one year

Unadjusted limits $7 / 8 / 9 /$

Adjusted limits

Actual

Margin

Of which: external debt of 1-5 year maturity

Limits

Margin

External payments arrears of the public sector (on a

continuous basis)

Limits

Actual

NPV of future government payments associated with PPP

operations (on a continuous basis)

Unadjusted Limits 10/

Actual

Margin

44

336

350

50

50

(Consultation bands for the 12-month rate of inflation, in percent) 11/

Outer band (upper limit)

Inner band (upper limit)

Central point

Inner band (lower limit)

Outer band (lower limit)

$\begin{array}{rrrr}5.5 & 5.5 & 5.5 & 5.5 \\ 4.5 & 4.5 & 4.5 & 4.5 \\ 2.5 & 2.5 & 2.5 & 2.5 \\ 0.5 & 0.5 & 0.5 & 0.5 \\ -0.5 & -0.5 & -0.5 & -0.5 \\ & & & \\ 0.3 & \ldots & \ldots & \cdots\end{array}$

\section{Sources: Staff estimations.}

1/ PIPP proceeds are included below the line.

2/ The limit on the borrowing requirement of the combined public sector will be adjusted downwards by the amount central government revenues net of mandatory transfers exceed program estimates of S/. 10,489 million at end-March, up to a ceiling of S/. 250 million; S/. 23,359 million at end-June, up to a ceiling of S/. 500 million; S/. 32, 807 million at end-September, up to a ceiling of S/. 750 million; and S/. 44,821 million at end-December, up to a total ceiling of S/. 1,000 million.

$3 /$ The limit on the borrowing requirement of the combined public sector will be adjusted for the operating balance of the BCRP.

4/ The limit on the borrowing requirement of the combined public sector will be adjusted upward by up to US $\$ 100$ million for capital spending by Petroperu, over the $\$ 30$ million already included in the program.

5/ The target for net international reserves will be adjusted upward by the amount by which net foreign borrowing of the nonfinancial public sector exceeds '-US $\$ 15$ million at end-March, -US\$138 million at end-June, -US\$274 million at end-September, and -US\$148 million at end-December 2007. It will be adjusted downward for shortfalls from programmed net foreign borrowing. The amounts in excess will be deposited at the BCRP.

6/ The target for net international reserves will be adjusted downward for withdrawals for portfolio management purposes of deposits held at the Central Reserve Bank by the Consolidated Pension Reserve Fund (FCR) and any other funds managed by the ONP. This downward adjustment will not exceed US $\$ 300$ million at any time in 2007.

7/ The limit will be adjusted upward by any amount of debt issued, and used in, debt-exchange operations, or for prefinancing of government operations.

8/ The current debt limits do not include contracting of non-guaranteed debt by Petroperu and will be adjusted upward by up to US $\$ 300$ million for debt contracted by Petroperu during 2007

9/ The limit on contracting and guaranteeing of nonconcessional public debt will be adjusted upwards for guarantees contracted or extended by the government in relation to concessions, up to a ceiling of US $\$ 430$ million for the year as a whole.

$10 /$ Discount rates to calculate the NPV of the future stream of payments will be the currency-specific commercial interest reference rates (CIRRs) published by the OECD and specified in the TMU.

11/ Should inflation fall outside the inner band, the authorities will discuss with the Fund staff the appropriate policy response. Should inflation fall outside the outer band, the authorities will also complete a consultation with the Executive Board of the Fund on the proposed policy response before requesting further purchases under the arrangement. 
Table 3. Peru: Structural Benchmarks for 2007

\begin{tabular}{|c|c|c|}
\hline Measures & $\begin{array}{l}\text { Date of } \\
\text { Implementation }\end{array}$ & Current Status \\
\hline $\begin{array}{l}\text { Publication of the main recommendations of the CIAS } \\
\text { on an anti-poverty strategy. }\end{array}$ & March 31, 2007 & Observed. \\
\hline $\begin{array}{l}\text { Establishment of a unit at the Ministry of Finance to } \\
\text { monitor the operations of subnational governments } \\
\text { and assess their performance with respect to fiscal } \\
\text { rules. }\end{array}$ & March 31, 2007 & Observed. \\
\hline $\begin{array}{l}\text { Clarify the tax treatment of financial derivatives and } \\
\text { securitized transactions. }\end{array}$ & March 31, 2007 & $\begin{array}{l}\text { Substantially observed. } \\
\text { Tax treatment of } \\
\text { securitized transactions } \\
\text { is expected to be } \\
\text { clarified by December } \\
31,2007 \text {. }\end{array}$ \\
\hline $\begin{array}{l}\text { Submit to congress a legal framework for PPP } \\
\text { operations. }\end{array}$ & June 30, 2007 & $\begin{array}{l}\text { Reprogrammed for } \\
\text { September 30, } 2007 .\end{array}$ \\
\hline $\begin{array}{l}\text { Ensure that most of new mortgage loans extended by } \\
\text { banks with the guarantee of MiVivienda are } \\
\text { denominated in nuevo soles. }\end{array}$ & June 30, 2007 & $N / A$ \\
\hline $\begin{array}{l}\text { Full implementation of the Treasury Single Account } \\
\text { (TSA) for the central government. }\end{array}$ & December 31, 2007 & $N / A$ \\
\hline $\begin{array}{l}2008 \text { Budget prepared according to the modernized } \\
\text { budget classification system and incorporated into the } \\
\text { charts of accounts. }\end{array}$ & December 31, 2007 & $\mathrm{~N} / \mathrm{A}$ \\
\hline $\begin{array}{l}\text { Financial transactions tax rate reduced, effective } \\
\text { January } 1,2008 .\end{array}$ & December 31, 2007 & $\begin{array}{l}\text { Observed. A decree was } \\
\text { issued in March } 2007 .\end{array}$ \\
\hline $\begin{array}{l}\text { Issue new regulations regarding new risk categories } \\
\text { and provisions to address foreign currency risk. }\end{array}$ & December 31, 2007 & $N / A$ \\
\hline
\end{tabular}


Table 4. Peru: Fiscal Operations of the Combined Public Sector (In percent of GDP; unless otherwise indicated)

\begin{tabular}{|c|c|c|c|c|c|c|c|c|}
\hline & \multirow[b]{3}{*}{2003} & \multirow[b]{3}{*}{2004} & \multirow[b]{3}{*}{2005} & \multirow{3}{*}{$\begin{array}{r}\begin{array}{r}\text { Country } \\
\text { Report } 07 / 54\end{array} \\
2006\end{array}$} & \multirow{3}{*}{ Prel. } & \multirow{3}{*}{$\begin{array}{l}\text { Prog. } \\
2007\end{array}$} & \multirow{2}{*}{\multicolumn{2}{|c|}{ Projection }} \\
\hline & & & & & & & & \\
\hline & & & & & & & 2007 & 2008 \\
\hline Central government primary balance & 0.2 & 0.6 & 1.1 & 2.5 & 3.2 & 1.1 & 1.3 & 1.3 \\
\hline Revenue & 14.9 & 15.0 & 15.8 & 17.4 & 17.4 & 16.5 & 17.3 & 16.9 \\
\hline Current & 14.7 & 14.9 & 15.7 & 17.2 & 17.2 & 16.4 & 17.2 & 16.8 \\
\hline Of which: Tax revenue & 12.8 & 13.2 & 13.6 & 15.1 & 14.9 & 14.5 & 15.2 & 15.0 \\
\hline Of which: Financial transaction tax & $\ldots$ & 0.3 & 0.3 & 0.3 & 0.3 & 0.3 & 0.3 & 0.3 \\
\hline Capital & 0.2 & 0.1 & 0.1 & 0.1 & 0.1 & 0.1 & 0.1 & 0.1 \\
\hline Noninterest expenditure & 14.7 & 14.4 & 14.7 & 14.9 & 14.1 & 15.4 & 15.9 & 15.6 \\
\hline Current $1 /$ & 12.8 & 12.6 & 12.8 & 13.1 & 12.2 & 12.7 & 13.0 & 12.3 \\
\hline Capital & 1.9 & 1.8 & 1.9 & 1.8 & 2.0 & 2.7 & 3.0 & 3.3 \\
\hline Rest of the general government primary balance & 0.3 & 0.3 & 0.3 & 0.2 & 0.4 & 0.1 & 0.5 & 0.0 \\
\hline Revenue & 5.8 & 5.7 & 5.9 & 6.1 & 6.2 & 5.9 & 6.6 & 6.0 \\
\hline Current & 5.7 & 5.7 & 5.9 & 5.9 & 5.9 & 5.9 & 6.5 & 5.9 \\
\hline Capital & 0.1 & 0.0 & 0.1 & 0.2 & 0.3 & 0.0 & 0.1 & 0.1 \\
\hline Noninterest expenditure & 5.5 & 5.4 & 5.7 & 5.8 & 5.8 & 5.8 & 6.0 & 6.0 \\
\hline Current & 4.6 & 4.6 & 4.7 & 4.8 & 4.7 & 4.7 & 4.6 & 4.6 \\
\hline Capital & 0.9 & 0.9 & 1.0 & 1.0 & 1.1 & 1.1 & 1.5 & 1.5 \\
\hline Public enterprise primary balance & 0.0 & 0.1 & 0.2 & 0.1 & 0.3 & 0.1 & 0.0 & -0.1 \\
\hline Current balance & 0.3 & 0.4 & 0.5 & 0.4 & 0.5 & 0.5 & 0.3 & 0.3 \\
\hline Capital balance & -0.4 & -0.2 & -0.3 & -0.3 & -0.2 & -0.4 & -0.3 & -0.3 \\
\hline Nonfinancial public sector primary balance & 0.4 & 1.0 & 1.6 & 2.8 & 3.9 & 1.3 & 1.8 & 1.2 \\
\hline Central bank operating balance & 0.1 & 0.0 & 0.0 & 0.1 & 0.2 & 0.0 & 0.1 & 0.0 \\
\hline Combined public sector primary balance & 0.5 & 1.0 & 1.6 & 3.0 & 4.1 & 1.3 & 1.9 & 1.2 \\
\hline Interest payments & 2.2 & 2.0 & 1.9 & 2.0 & 1.9 & 2.0 & 1.8 & 1.7 \\
\hline External & 1.8 & 1.7 & 1.6 & 1.5 & 1.4 & 1.4 & 1.4 & 1.2 \\
\hline Domestic & 0.4 & 0.4 & 0.4 & 0.5 & 0.4 & 0.6 & 0.5 & 0.5 \\
\hline Combined public sector overall balance & -1.7 & -1.1 & -0.3 & 1.0 & 2.2 & -0.8 & 0.0 & -0.5 \\
\hline Financing & 1.7 & 1.1 & 0.3 & -1.0 & -2.2 & 0.8 & 0.0 & 0.5 \\
\hline External & 1.4 & 1.5 & -1.3 & -0.2 & -0.6 & -0.2 & 0.0 & -0.5 \\
\hline Disbursements 2/ & 3.4 & 3.6 & 3.4 & 1.1 & 0.7 & 1.0 & 3.2 & 0.9 \\
\hline Amortization $3 /$ & -1.9 & -1.9 & -4.6 & -1.3 & -1.3 & -1.2 & -3.3 & -1.5 \\
\hline Rescheduling/arrears (net) & 0.0 & 0.0 & 0.0 & 0.0 & 0.0 & 0.0 & 0.0 & 0.0 \\
\hline Other $4 /$ & -0.1 & -0.1 & -0.1 & 0.0 & 0.0 & 0.0 & 0.1 & 0.0 \\
\hline Domestic & 0.2 & -0.6 & 1.6 & -0.9 & -1.7 & 0.9 & -0.1 & 1.0 \\
\hline Bond placements $5 /$ & 0.8 & 1.1 & 2.6 & 1.9 & 1.8 & 0.7 & 1.6 & 1.1 \\
\hline Amortization 6/ & -0.9 & -1.0 & -1.0 & -1.5 & -1.5 & -0.4 & -1.2 & -0.5 \\
\hline Net deposits & 0.3 & -0.7 & 0.0 & -1.4 & -2.1 & 0.6 & -0.5 & 0.4 \\
\hline Privatization & 0.1 & 0.2 & 0.1 & 0.1 & 0.1 & 0.0 & 0.0 & 0.0 \\
\hline \multicolumn{9}{|l|}{ Memorandum items: } \\
\hline Combined public sector overall balance (including CRPAOs) & -1.7 & -1.1 & -0.3 & 0.9 & 2.1 & -1.2 & -0.3 & -0.9 \\
\hline General government current revenue $7 /$ & 17.4 & 17.5 & 18.3 & 19.6 & 19.6 & 18.5 & 19.6 & 19.1 \\
\hline General government noninterest expenditure $7 /$ & 17.1 & 16.7 & 17.0 & 16.9 & 16.1 & 17.4 & 17.8 & 17.9 \\
\hline Public sector debt (including CRPAOs) & 47.0 & 44.4 & 37.7 & 32.0 & 32.7 & 31.2 & 30.0 & 28.8 \\
\hline Nominal GDP (S/. billions) & 213.9 & 237.8 & 261.6 & 298.9 & 305.8 & 317.9 & 329.2 & 349.0 \\
\hline
\end{tabular}

Sources: Central Reserve Bank of Peru; Ministry of Economy and Finance; and Fund staff estimates/projections.

1/ Revised projection for 2007 accommodates the acceleration of transfers associated with income tax payments from the extractive industries to sub-national governments

2/ In 2004, includes placement of US $\$ 800$ million euro-denominated bonds, covering part of the country's financing needs for 2005. In 2005, includes placement of US $\$ 750$ million bonds to finance the Paris Club prepayment. In 2007 (the projection column), includes the swap of $\$ 2.3$ billion to extend the average maturity of public debt.

$3 /$ In 2005, includes the prepayment of US $\$ 1.55$ billion to the Paris Club. In 2007 (the projection column), includes the swap of $\$ 2.3$ billion to extend the average maturity of public debt.

4/ Includes condonations, plus the net increase in short-term external credit to the NFPS and the net decrease in foreign assets of the NFPS.

$5 /$ In 2005, includes the placement of US $\$ 323$ and US $\$ 462$ million Soles-denominated bonds to finance the Paris Club prepayment. In 2006, includes the placement of US $\$ 85$ million Soles-denominated bonds to finance the Japeco prepayment.

6 / Includes in 2005 the amortization of US $\$ 390$ million U.S. dollar denominated domestic bonds for the restructuring of the financial sector

7/ Net of transfers among non-financial public institutions. 
Table 5. Peru: Fiscal Operations of the Combined Public Sector (In billions of Soles; unless otherwise indicated)

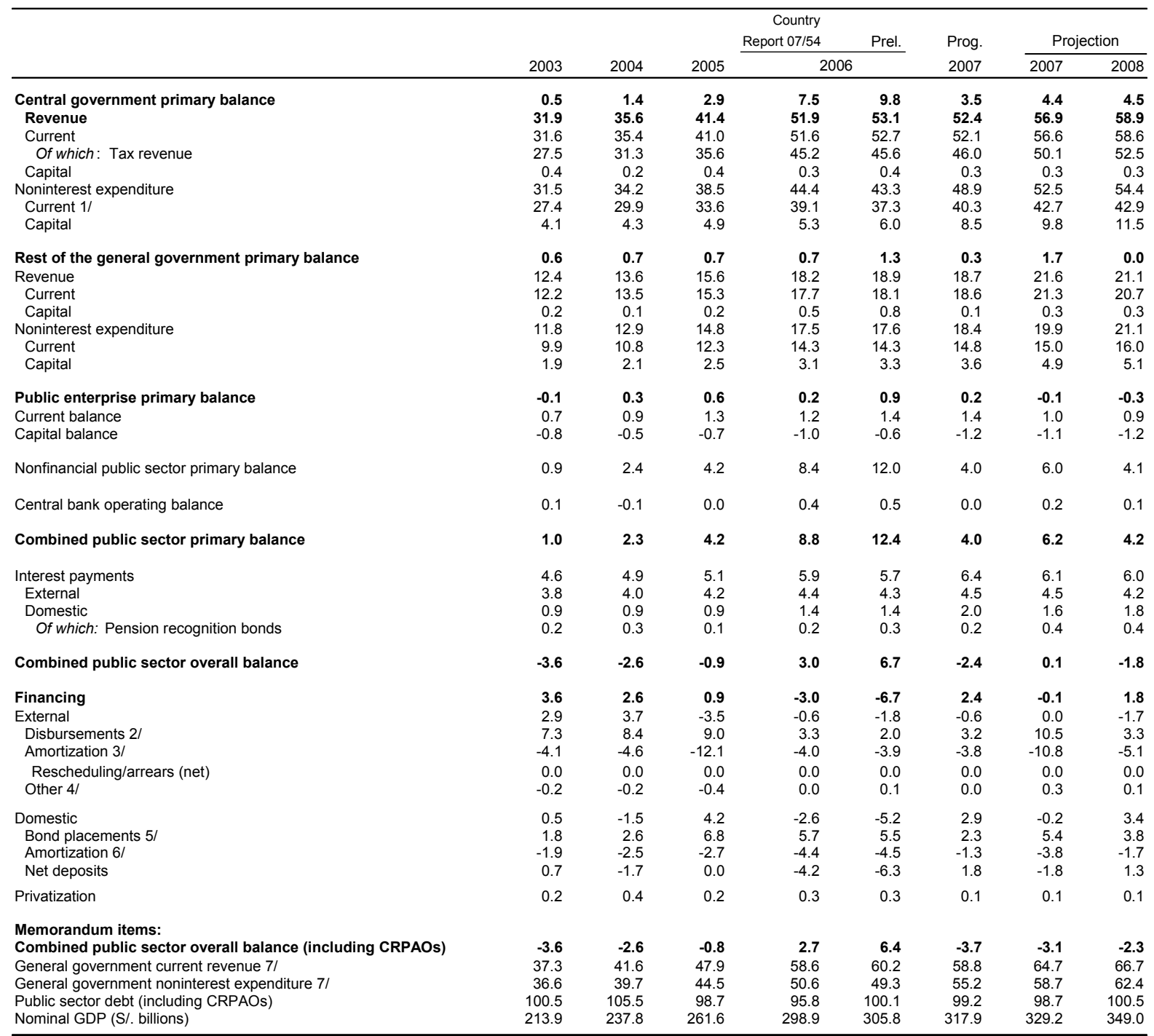

Sources: Central Reserve Bank of Peru; Ministry of Economy and Finance; and Fund staff estimates/projections.

1/ Revised projection for 2007 accommodates the acceleration of transfers associated with income tax payments from the extractive industries to sub-national governments.

$2 /$ In 2004, includes placement of US $\$ 800$ million euro-denominated bonds, covering part of the country's financing needs for 2005 . In 2005, includes placement of US $\$ 750$ million bonds to finance the Paris Club prepayment. In 2007 (the projection column), includes the swap of $\$ 2.3$ billion to extend the average maturity of public debt.

$3 /$ In 2005, includes the prepayment of US $\$ 1.55$ billion to the Paris Club. In 2007 (the projection column), includes the swap of $\$ 2.3$ billion to extend the average maturity of public debt.

4/ Includes condonations, plus the net increase in short-term external credit to the NFPS and the net decrease in foreign assets of the NFPS. $5 /$ In 2005, includes the placement of US $\$ 323$ and US $\$ 462$ million Soles-denominated bonds to finance the Paris Club prepayment. In 2006 , includes the placement of US $\$ 85$ million Soles-denominated bonds to finance the Japeco prepayment.

6/ Includes in 2005 the amortization of US $\$ 390$ million U.S. dollar denominated domestic bonds for the restructuring of the financial sector.

7/ Net of transfers among non-financial public institutions. 
Table 6. Peru: Financing of the Combined Public Sector

\begin{tabular}{|c|c|c|c|c|c|c|c|}
\hline & \multirow[b]{2}{*}{2003} & \multirow[b]{2}{*}{2004} & \multirow[b]{2}{*}{2005} & \multirow{2}{*}{$\begin{array}{l}\text { Prel. } \\
2006\end{array}$} & \multirow{2}{*}{$\begin{array}{l}\text { Prog. } \\
2007\end{array}$} & \multicolumn{2}{|c|}{ Projection } \\
\hline & & & & & & 2007 & 2008 \\
\hline \multicolumn{8}{|c|}{ (In millions of U.S. dollars) } \\
\hline Combined balance & $-1,037$ & -748 & -262 & 2,056 & -746 & 32 & -565 \\
\hline Financing & 1,037 & 748 & 262 & $-2,056$ & 746 & -32 & 565 \\
\hline Net External & 843 & 1,078 & $-1,067$ & -560 & -174 & -9 & -533 \\
\hline Disbursements & 2,101 & 2,474 & 2,728 & 609 & 1,000 & 3,294 & 1,020 \\
\hline Bonds $1 / 2$ / & 1,245 & 1,295 & 1,682 & 0 & 0 & 2,290 & 0 \\
\hline Multilaterals & 519 & 863 & 595 & 315 & 400 & 404 & 420 \\
\hline Bilaterals and other & 337 & 315 & 451 & 294 & 600 & 600 & 600 \\
\hline Amortization 3/ 4/ & $-1,187$ & $-1,348$ & $-3,678$ & $-1,195$ & $-1,174$ & $-3,392$ & $-1,592$ \\
\hline Other $5 /$ & -71 & -48 & -117 & 27 & 0 & 89 & 40 \\
\hline Privatization & 52 & 114 & 56 & 94 & 24 & 40 & 25 \\
\hline Net Domestic financing & 142 & -443 & 1,273 & $-1,590$ & 897 & -62 & 1,073 \\
\hline Bonds 6/ & 508 & 759 & 2,071 & 1,701 & 723 & 1,675 & 1,200 \\
\hline Amortization & -556 & -719 & -811 & $-1,372$ & -387 & $-1,190$ & -544 \\
\hline Of which: Pension recognition bonds & -170 & -215 & -188 & -145 & -95 & -158 & -170 \\
\hline Net deposits & 190 & -483 & 13 & $-1,919$ & 561 & -548 & 417 \\
\hline Of which: Central government & 299 & -335 & 348 & $-1,227$ & 582 & -81 & 213 \\
\hline \multicolumn{8}{|c|}{ (In percent of GDP) } \\
\hline Combined balance & -1.7 & -1.1 & -0.3 & 2.2 & -0.8 & 0.0 & -0.5 \\
\hline Financing & 1.7 & 1.1 & 0.3 & -2.2 & 0.8 & -0.0 & 0.5 \\
\hline Net External & 1.4 & 1.5 & -1.3 & -0.6 & -0.2 & -0.0 & -0.5 \\
\hline Disbursements 1/ & 3.4 & 3.6 & 3.4 & 0.7 & 1.0 & 3.2 & 0.9 \\
\hline Bonds & 2.0 & 1.9 & 2.1 & 0.0 & 0.0 & 2.2 & 0.0 \\
\hline Multilaterals & 0.8 & 1.2 & 0.7 & 0.3 & 0.4 & 0.4 & 0.4 \\
\hline Bilaterals and other & 0.5 & 0.5 & 0.6 & 0.3 & 0.6 & 0.6 & 0.5 \\
\hline Amortization & -1.9 & -1.9 & -4.6 & -1.3 & -1.2 & -3.3 & -1.5 \\
\hline Other & -0.1 & -0.1 & -0.1 & 0.0 & 0.0 & 0.1 & 0.0 \\
\hline Privatization & 0.1 & 0.2 & 0.1 & 0.1 & 0.0 & 0.0 & 0.0 \\
\hline Net Domestic financing & 0.2 & -0.6 & 1.6 & -1.7 & 0.9 & -0.1 & 1.0 \\
\hline Bonds & 0.8 & 1.1 & 2.6 & 1.8 & 0.7 & 1.6 & 1.1 \\
\hline Amortization & -0.9 & -1.0 & -1.0 & -1.5 & -0.4 & -1.2 & -0.5 \\
\hline Of which: Pension recognition bonds & -0.3 & -0.3 & -0.2 & -0.2 & -0.1 & -0.2 & -0.2 \\
\hline Net deposits & 0.3 & -0.7 & 0.0 & -2.1 & 0.6 & -0.5 & 0.4 \\
\hline Of which: Central government & 0.5 & -0.5 & 0.4 & -1.3 & 0.6 & -0.1 & 0.2 \\
\hline \multicolumn{8}{|l|}{ Memorandum items: } \\
\hline Net external financing (including CRPAOs) & 843.5 & $1,077.7$ & $-1,066.5$ & -459.5 & 226.0 & 389.5 & -51.4 \\
\hline Nominal GDP (S/. billions) & 213.9 & 237.8 & 261.6 & 305.8 & 317.9 & 329.2 & 349.0 \\
\hline
\end{tabular}

Sources: Central Reserve Bank of Peru; Ministry of Economy and Finance; and Fund staff estimates/projections.

$1 /$ In 2004, includes placement of US $\$ 800$ million euro-denominated bonds, covering part of the financing needs for 2005. In 2007 (the projection column), includes the swap of $\$ 2.3$ billion to extend the average maturity of public debt.

$2 /$ In 2005, includes placement of US $\$ 750$ million bonds to finance the Paris Club prepayment. In 2007 (the projection column), includes the swap of $\$ 2.3$ billion to extend the average maturity of public debt.

3 / Includes in 2005 the amortization of US $\$ 390$ million U.S. dollar denominated domestic bonds for the restructuring of the financial sector.

4/ In 2005, includes the prepayment of US $\$ 1.55$ billion to the Paris Club. In 2007 (the projection column), includes a swap of $\$ 2.3$ billion to extend the average maturity of debt.

$5 /$ Includes condonations, net increase in short-term external credit to the NFPS, and net decrease in foreign assets of the NFPS.

$6 /$ In 2005, includes the placement of US $\$ 323$ and US $\$ 462$ million Soles-denominated bonds to finance the Paris Club prepayment. In 2006, includes the placement of US\$85 million Soles-denominated bonds to finance the Japeco prepayment. 
Table 7. Peru: Public Sector Social Expenditure

\begin{tabular}{|c|c|c|c|c|c|c|}
\hline & 2002 & 2003 & 2004 & 2005 & $\begin{array}{l}\text { Prel. } \\
2006\end{array}$ & $\begin{array}{l}\text { Proj. } \\
2007\end{array}$ \\
\hline \multicolumn{7}{|c|}{ (In millions of New Soles) } \\
\hline Total social expenditure and pensions & 20,698 & 21,613 & 23,578 & 25,764 & 27,736 & 29,379 \\
\hline Universal coverage (Education and Health) $1 /$ & 8,197 & 8,916 & 10,396 & 10,954 & 12,689 & 13,822 \\
\hline Education & 5,759 & 6,366 & 7,289 & 7,718 & 8,341 & 9,048 \\
\hline Health & 2,438 & 2,550 & 3,107 & 3,235 & 4,348 & 4,774 \\
\hline Targeted programs (Extreme Poverty) & 2,840 & 2,988 & 2,994 & 3,447 & 3,185 & 3,455 \\
\hline Non-Targeted Social Programs & 9,661 & 9,710 & 10,187 & 11,364 & 11,862 & 12,102 \\
\hline \multicolumn{7}{|c|}{ (In percent of general government expenditure) } \\
\hline Total social expenditure and pensions & 53.5 & 52.6 & 53.0 & 52.0 & 50.5 & 45.5 \\
\hline Universal coverage (Education and Health) $1 /$ & 21.2 & 21.7 & 23.4 & 22.1 & 23.1 & 21.4 \\
\hline Education & 14.9 & 15.5 & 16.4 & 15.6 & 15.2 & 14.0 \\
\hline Health & 6.3 & 6.2 & 7.0 & 6.5 & 7.9 & 7.4 \\
\hline Targeted programs (Extreme Poverty) 2/ & 7.3 & 7.3 & 6.7 & 7.0 & 5.8 & 5.3 \\
\hline Non-Targeted Social Programs & 25.0 & 23.6 & 22.9 & 22.9 & 21.6 & 18.7 \\
\hline \multicolumn{7}{|c|}{ (In percent of GDP) } \\
\hline Total social expenditure and pensions & 10.3 & 10.1 & 9.9 & 9.8 & 9.1 & 8.9 \\
\hline Universal coverage (Education and Health) $1 /$ & 4.1 & 4.2 & 4.4 & 4.2 & 4.1 & 4.2 \\
\hline Education & 2.9 & 3.0 & 3.1 & 3.0 & 2.7 & 2.7 \\
\hline Health & 1.2 & 1.2 & 1.3 & 1.2 & 1.4 & 1.5 \\
\hline Targeted programs (Extreme Poverty) & 1.4 & 1.4 & 1.3 & 1.3 & 1.0 & 1.0 \\
\hline Non-Targeted Social Programs & 4.8 & 4.5 & 4.3 & 4.3 & 3.9 & 3.7 \\
\hline \multicolumn{7}{|l|}{ Memorandum items: } \\
\hline $\begin{array}{l}\text { Total social expenditure and pensions (annual percentage } c \\
\text { deflated by } \mathrm{CPI} \text { ) }\end{array}$ & 8.4 & 2.2 & 5.9 & 7.6 & 5.3 & 4.9 \\
\hline General government expenditure (in millions of New Soles) & 38,721 & 41,098 & 44,475 & 49,565 & 54,915 & 64,636 \\
\hline
\end{tabular}

Source: Ministry of Economy and Finance.

$1 /$ Net of spending on education and health already included in the extreme poverty programs.

2/ Includes expenditures for the targeted poverty-reduction program Juntos in 2006. 
Table 8. Peru: Monetary Survey

\begin{tabular}{|c|c|c|c|c|c|c|c|}
\hline & \multirow[b]{2}{*}{2003} & \multirow[b]{2}{*}{2004} & \multirow[b]{2}{*}{2005} & \multirow{2}{*}{$\begin{array}{l}\text { Prel. } \\
2006\end{array}$} & \multirow{2}{*}{$\begin{array}{l}\text { Prog. } \\
2007\end{array}$} & \multicolumn{2}{|c|}{ Projection } \\
\hline & & & & & & 2007 & 2008 \\
\hline \multicolumn{8}{|c|}{$\begin{array}{c}\text { I. Central Reserve Bank } \\
\text { (In millions of New Soles at program exchange rate) }\end{array}$} \\
\hline Net international reserves $1 /$ & 36,393 & 43,111 & 46,594 & 56,566 & 54,260 & 68,930 & 69,536 \\
\hline (In millions of U.S. dollars) & 10,194 & 12,631 & 14,097 & 17,275 & 16,747 & 21,275 & 21,775 \\
\hline Net domestic assets & $-30,023$ & $-35,075$ & $-36,478$ & $-44,770$ & $-41,689$ & $-55,219$ & $-54,389$ \\
\hline Net credit to nonfinancial public sector & $-10,709$ & $-12,974$ & $-13,888$ & $-20,061$ & $-15,907$ & $-23,224$ & $-22,782$ \\
\hline Rest of banking system & $-14,757$ & $-19,146$ & $-21,384$ & $-21,906$ & $-23,916$ & $-27,216$ & $-27,796$ \\
\hline Other & $-4,557$ & $-2,955$ & $-1,206$ & $-2,802$ & $-1,867$ & $-4,779$ & $-3,810$ \\
\hline Currency & 6,370 & 8,036 & 10,116 & 11,796 & 12,571 & 13,711 & 15,147 \\
\hline \multicolumn{8}{|c|}{$\begin{array}{l}\text { II. Banking System } \\
\text { millions of New Soles at program exchang }\end{array}$} \\
\hline Net foreign assets & 36,186 & 42,562 & 45,851 & 57,359 & 58,657 & 68,746 & 69,355 \\
\hline Net domestic assets & 17,597 & 15,809 & 20,404 & 17,075 & 22,414 & 15,940 & 23,438 \\
\hline Net credit to nonfinancial public sector & $-10,664$ & $-13,437$ & $-14,307$ & $-21,290$ & $-17,342$ & $-26,274$ & $-25,115$ \\
\hline Net credit to private sector & 44,876 & 44,990 & 49,504 & 54,736 & 63,173 & 61,095 & 66,809 \\
\hline Other & $-16,615$ & $-15,744$ & $-14,793$ & $-16,371$ & $-23,417$ & $-18,881$ & $-18,257$ \\
\hline Net credit to COFIDE & $-1,018$ & $-1,087$ & -850 & -850 & -850 & -850 & -850 \\
\hline Other & $-15,597$ & $-14,657$ & $-13,943$ & $-15,521$ & $-22,567$ & $-18,031$ & $-17,407$ \\
\hline Liabilities to the private sector & 53,783 & 58,371 & 66,255 & 74,434 & 81,071 & 84,686 & 92,792 \\
\hline \multicolumn{8}{|c|}{ (12-month percentage change) } \\
\hline Base money & 10.1 & 25.3 & 25.7 & 18.3 & 10.0 & 15.4 & 10.8 \\
\hline Broad money & 2.5 & 8.5 & 13.5 & 12.3 & 9.3 & 13.8 & 9.6 \\
\hline Domestic currency & 10.5 & 28.1 & 19.5 & 18.0 & 15.9 & 21.4 & 15.3 \\
\hline Foreign currency $2 /$ & -1.8 & -3.1 & 8.8 & 7.5 & 3.0 & 6.6 & 3.4 \\
\hline Net credit to private sector & -2.9 & 0.3 & 10.0 & 10.6 & 8.0 & 11.6 & 9.4 \\
\hline Domestic currency & 5.1 & 11.9 & 34.8 & 29.0 & 23.7 & 28.6 & 20.2 \\
\hline Foreign currency $2 /$ & -5.0 & -3.2 & 1.6 & 2.3 & 0.0 & 2.0 & 1.6 \\
\hline \multicolumn{8}{|c|}{ III. Financial System } \\
\hline Net foreign assets & 35,928 & 42,425 & 45,775 & 57,336 & 61,674 & 65,936 & 67,255 \\
\hline Net domestic assets & 38,820 & 41,818 & 54,504 & 66,982 & 53,695 & 80,393 & 95,493 \\
\hline Net credit to the public sector & $-8,976$ & $-10,442$ & $-7,599$ & $-10,927$ & $-6,911$ & $-13,113$ & $-11,802$ \\
\hline Net credit to private sector & 62,666 & 65,914 & 73,377 & 87,626 & 86,777 & 99,832 & 108,803 \\
\hline Other & $-14,871$ & $-13,655$ & $-11,274$ & $-9,716$ & $-26,171$ & $-6,327$ & $-1,508$ \\
\hline Liabilities to the private sector & $\mathbf{7 4 , 7 4 8}$ & 84,243 & 100,278 & 124,318 & 115,369 & 146,329 & 162,748 \\
\hline \multicolumn{8}{|c|}{ (12-month percentage change) } \\
\hline Liabilities to the private sector & 13.5 & 12.7 & 19.0 & 24.0 & 8.0 & 17.7 & 11.2 \\
\hline Domestic currency & 24.3 & 23.5 & 28.9 & 30.6 & 12.0 & 24.0 & 15.0 \\
\hline Foreign currency $2 /$ & 3.7 & 0.9 & 6.0 & 13.4 & 1.0 & 6.0 & 3.0 \\
\hline Net credit to private sector & 3.7 & 5.2 & 11.3 & 19.4 & 7.5 & 13.9 & 9.0 \\
\hline Domestic currency & 18.0 & 17.9 & 26.6 & 37.6 & 15.0 & 25.0 & 15.0 \\
\hline Foreign currency $2 /$ & -1.9 & -0.9 & 2.7 & 6.8 & 1.5 & 4.0 & 2.5 \\
\hline \multicolumn{8}{|l|}{ Memorandum item: } \\
\hline Program exchange rate (S/. per US\$) & 3.48 & 3.41 & 3.31 & 3.27 & 3.24 & 3.24 & 3.19 \\
\hline
\end{tabular}

Sources: Central Reserve Bank of Peru; and Fund staff estimates/projections.

1/ Excludes subscriptions to the IMF and the Latin American Reserve Fund (FLAR), Pesos Andinos, credit lines to other central banks, as well as Corporacion Andina de Fomento (CAF) bonds, and foreign assets temporarily held by the BCRP as part of swap operations.

2/ Flows in foreign currency are valued at the program exchange rate. 
Table 9. Peru: Financial Soundness Indicators 1/ (In percent; unless otherwise indicated)

\begin{tabular}{|c|c|c|c|c|c|c|c|}
\hline & Dec-01 & Dec-02 & Dec-03 & Dec-04 & Dec-05 & Dec-06 & Mar-07 \\
\hline \multicolumn{8}{|l|}{ Capital Adequacy } \\
\hline Equity capital to risk-weighted assets & 12.8 & 12.5 & 13.3 & 14.0 & 12.0 & 12.5 & 12.5 \\
\hline Regulatory Tier I capital to risk-weighted assets $2 /$ & 12.4 & 13.0 & 12.1 & 13.1 & 11.2 & 10.6 & 10.7 \\
\hline Nonperforming loans net of provisions to capital & -11.1 & -17.2 & -15.2 & -17.3 & -21.7 & -18.0 & -17.2 \\
\hline \multicolumn{8}{|l|}{ Asset Quality } \\
\hline Nonperforming loans to total gross loans $3 /$ & 9.0 & 7.6 & 5.8 & 3.7 & 2.1 & 1.6 & 1.6 \\
\hline In domestic currency & 5.2 & 5.2 & 4.0 & 3.0 & 2.1 & 1.9 & 1.9 \\
\hline In foreign currency & 9.9 & 8.2 & 6.3 & 3.9 & 2.2 & 1.5 & 1.5 \\
\hline Nonperforming loans to total gross loans 4 / & 17.0 & 14.6 & 12.2 & 9.5 & 6.3 & 4.1 & 3.9 \\
\hline In domestic currency & 9.9 & 8.8 & 6.6 & 6.1 & 4.2 & 3.2 & 3.1 \\
\hline In foreign currency & 19.0 & 16.4 & 14.1 & 10.6 & 7.1 & 4.6 & 4.3 \\
\hline Refinanced and restructured loans to total gross loans $5 /$ & 8.0 & 7.0 & 6.4 & 5.8 & 4.1 & 2.4 & 2.2 \\
\hline Provisions to nonperforming loans $3 /$ & 118.9 & 133.2 & 141.1 & 176.5 & 235.3 & 251.4 & 246.5 \\
\hline Provisions to nonperforming, restructured, and refinanced loans 4 / & 63.0 & 69.1 & 67.1 & 68.7 & 80.3 & 100.3 & 104.3 \\
\hline \multicolumn{8}{|l|}{ Sectoral distribution of loans to total loans } \\
\hline Consumer loans & 8.6 & 9.4 & 11.6 & 13.4 & 14.4 & 16.5 & 17.0 \\
\hline Mortgage loans & 9.6 & 10.7 & 12.9 & 14.2 & 14.8 & 14.0 & 14.0 \\
\hline Commercial loans & 79.2 & 77.6 & 72.6 & 68.1 & 65.8 & 64.2 & 63.6 \\
\hline Small business loans & 2.5 & 2.3 & 2.9 & 4.3 & 5.0 & 5.3 & 5.4 \\
\hline \multicolumn{8}{|l|}{ Earnings and Profitability } \\
\hline ROA & 0.4 & 0.8 & 1.1 & 1.2 & 2.2 & 2.2 & 2.4 \\
\hline ROE & 4.3 & 8.3 & 10.7 & 11.6 & 22.2 & 23.9 & 25.8 \\
\hline Gross financial spread to financial revenues & 51.9 & 66.1 & 71.2 & 71.9 & 70.5 & 67.6 & 69.2 \\
\hline Financial revenues to total revenues & 78.7 & 72.7 & 70.6 & 69.1 & 76.3 & 76.6 & 80.2 \\
\hline Annualized financial revenues to revenue-generating assets & 11.6 & 9.9 & 9.2 & 9.0 & 10.3 & 10.6 & 11.0 \\
\hline \multicolumn{8}{|l|}{ Liquidity } \\
\hline Total liquid assets to total short-term liabilities & 39.2 & 41.9 & 40.4 & 44.5 & 45.5 & 44.2 & 44.9 \\
\hline In domestic currency & 22.6 & 23.5 & 32.9 & 44.8 & 38.6 & 43.1 & 48.1 \\
\hline In foreign currency & 46.0 & 49.3 & 43.9 & 44.3 & 49.2 & 45.0 & 42.6 \\
\hline \multicolumn{8}{|l|}{ Foreign Currency Position and Dollarization } \\
\hline Global position in foreign currency to regulatory capital 6/ & 37.6 & 37.0 & 31.8 & 24.2 & 23.1 & 17.1 & 30.2 \\
\hline Share of foreign currency deposits in total deposits & 71.9 & 71.6 & 69.7 & 67.1 & 67.2 & 62.7 & 60.7 \\
\hline Share of foreign currency loans in total credit & 80.5 & 79.7 & 77.9 & 75.7 & 71.5 & 65.5 & 64.7 \\
\hline Foreign currency deposits at commercial banks (in millions of U.S. dollars) & 9,357 & 9,658 & 9,210 & 9,596 & 10,913 & 11,855 & 11,993 \\
\hline Commercial banks' short-term foreign assets (in millions of U.S. dollars) & 748 & 779 & 601 & 547 & 796 & 878 & 758 \\
\hline Commercial banks' short-term foreign liabilities (in millions of U.S. dollars) & 1,161 & 763 & 702 & 733 & 1,085 & 754 & 712 \\
\hline \multicolumn{8}{|l|}{ Operational efficiency } \\
\hline Financing to related parties to capital $7 /$ & $\ldots$ & 20.1 & 18.7 & 14.3 & 17.9 & 15.5 & 16.6 \\
\hline Nonfinancial expenditure to total revenues $8 /$ & 32.1 & 36.2 & 37.7 & 35.9 & 33.3 & 31.3 & 29.8 \\
\hline Nonfinancial expenditure to total revenue-generating assets $8 /$ & 4.7 & 4.9 & 4.9 & 4.7 & 4.6 & 3.4 & 4.6 \\
\hline \multicolumn{8}{|l|}{ Memorandum items: } \\
\hline Number of Banks & 16 & 16 & 16 & 16 & 14 & 13 & 13 \\
\hline Private commercial & 15 & 14 & 14 & 14 & 12 & 11 & 11 \\
\hline Of which: Foreign-owned & 10 & 9 & 9 & 9 & 9 & 7 & 7 \\
\hline State-owned & 1 & 2 & 2 & 2 & 2 & 2 & 5 \\
\hline Banks' credit card loans to total loans & 2.4 & 3.3 & 4.6 & 6.4 & 6.9 & 8.1 & 8.2 \\
\hline Bank loans' 12 month increase (in real terms) & -3.3 & 1.0 & -8.3 & -1.9 & 19.0 & 14.0 & 17.2 \\
\hline Stock market index (U.S. dollars) & 342.1 & 396.0 & 700.6 & $1,131.6$ & $1,400.1$ & $4,032.0$ & $5,390.2$ \\
\hline Foreign currency debt rating (Moody's) & $\mathrm{Ba} 3$ & Ba3 & $\mathrm{Ba} 3$ & Ba3 & Ba3 & Ba3 & $\mathrm{Ba} 3$ \\
\hline Spread of Peruvian Brady bonds, basis points & 521 & 610 & 312 & 220 & 257 & 118 & 129 \\
\hline
\end{tabular}

Sources: Superintendency of Banks and Insurance of Peru; Central Bank of Peru; and Fund staff estimates/projections.

$1 /$ These indicators correspond to private commercial banks.

2/ Tier I regulatory capital is equivalent to share capital and reserves. Risk-weighted assets include market risk exposure. In year 2002, the Tier I considers a reduction on Banco Santander Central Hispano capital due to the valorization before its merger with Banco de Crédito.

3 / Nonperforming loans are overdue loans after 15 days since the due date for commercial loans, after 30 days for small bussines loans. In the case of mortgage, consumer and leasing loans, they are considered overdue after 30 days since the due date only for the non paid portion and after 90 days, for all the credit. The overdue loans include credits under judicial resolution.

$4 /$ Includes restructured loans, refinanced loans, and arrears.

5/ Refinanced loans refer to those loans subjected either term and/or principal modifications with respect to the initial debt contract. Restructured loans refer to those loans whose payments have been restructured according to the "Ley General del Sistema Concursal."

6/ Global position in foreign currency corresponds to those items in the balance sheet subject to exchange rate risk.

7/ Financing to related parties corresponds to those loans to individuals and firms owning more than 4 percent of the bank.

8/ Nonfinancial expenditures do not consider provisions nor depreciations. 
Table 10. Peru: Balance of Payments

(In millions of U.S. dollars)

\begin{tabular}{|c|c|c|c|c|c|c|c|}
\hline & \multirow[b]{2}{*}{2003} & \multirow[b]{2}{*}{2004} & \multirow[b]{2}{*}{2005} & \multirow{2}{*}{$\begin{array}{l}\text { Prel. } \\
2006\end{array}$} & \multirow{2}{*}{$\begin{array}{l}\text { Prog. } \\
2007\end{array}$} & \multicolumn{2}{|c|}{ Projection } \\
\hline & & & & & & 2007 & 2008 \\
\hline Current account & -935 & -11 & 1,033 & 2,456 & 151 & 877 & 551 \\
\hline Merchandise trade & 836 & 2,793 & 5,163 & 8,853 & 7,080 & 8,066 & 5,524 \\
\hline Exports & 9,091 & 12,617 & 17,247 & 23,750 & 24,705 & 25,974 & 25,705 \\
\hline Traditional & 6,356 & 9,028 & 12,839 & 18,332 & 18,867 & 19,766 & 18,616 \\
\hline Nontraditional and others & 2,734 & 3,589 & 4,408 & 5,417 & 5,838 & 6,208 & 7,089 \\
\hline Imports & $-8,255$ & $-9,824$ & $-12,084$ & $-14,897$ & $-17,625$ & $-17,908$ & $-20,181$ \\
\hline Services, income, and current transfers (net) & $-1,771$ & $-2,803$ & $-4,130$ & $-6,397$ & $-6,929$ & $-7,189$ & $-4,973$ \\
\hline Services & -854 & -843 & -912 & -932 & $-1,233$ & $-1,296$ & $-1,508$ \\
\hline Investment income & $-2,144$ & $-3,421$ & $-5,009$ & $-7,649$ & $-7,934$ & $-8,522$ & $-6,223$ \\
\hline Current transfers & 1,227 & 1,460 & 1,791 & 2,184 & 2,239 & 2,630 & 2,759 \\
\hline Financial and capital account & 1,414 & 2,337 & 495 & 270 & 971 & 2,969 & -90 \\
\hline Public sector & 684 & 988 & $-1,440$ & -639 & 150 & 135 & -148 \\
\hline Disbursements $1 /$ & 2,161 & 2,535 & 2,656 & 708 & 1,405 & 3,689 & 1,589 \\
\hline \multicolumn{8}{|l|}{ Other medium- and long-term } \\
\hline Public sector flows 2/ & -248 & -158 & -378 & -125 & -50 & -94 & -97 \\
\hline Capital transfers (net) & 0 & 0 & 0 & 0 & 0 & 0 & 0 \\
\hline Privatization & 10 & 31 & 31 & 79 & 10 & 0 & 39 \\
\hline Private sector & 720 & 1,318 & 1,905 & 831 & 811 & 2,834 & 19 \\
\hline \multicolumn{8}{|l|}{ Foreign direct investment (FDI) excluding } \\
\hline privatization & 1,265 & 1,785 & 2,489 & 3,388 & 2,233 & 2,893 & 2,849 \\
\hline Other private capital & $-1,233$ & -557 & -878 & $-1,884$ & $-1,421$ & -59 & $-2,829$ \\
\hline Medium- and long-term loans & -166 & -411 & -741 & 114 & -122 & 262 & 27 \\
\hline Portfolio investment & $-1,214$ & -376 & 75 & $-1,444$ & -910 & $-1,717$ & $-1,545$ \\
\hline Short-term flows $3 /$ & 147 & 231 & -213 & -554 & -390 & 1,395 & $-1,311$ \\
\hline Net Errors and Omissions & 688 & 90 & 295 & -674 & 0 & 0 & 0 \\
\hline Balance & 479 & 2,326 & 1,528 & 2,726 & 1,122 & 3,846 & 461 \\
\hline Financing & -479 & $-2,326$ & $-1,528$ & $-2,726$ & $-1,122$ & $-3,846$ & -461 \\
\hline NIR flow (increase -) & -477 & $-2,353$ & $-1,628$ & $-2,753$ & $-1,150$ & $-3,925$ & -500 \\
\hline Change in NIR (increase -) & -596 & $-2,437$ & $-1,466$ & $-3,178$ & $-1,150$ & $-4,000$ & -500 \\
\hline Valuation change & -119 & -84 & 162 & -425 & 0 & -75 & 0 \\
\hline Exceptional financing & -2 & 27 & 100 & 27 & 28 & 79 & 39 \\
\hline Debt relief $4 /$ & 70 & 27 & 100 & 27 & 28 & 79 & 39 \\
\hline Change in arrears & -72 & 0 & 0 & 0 & 0 & 0 & 0 \\
\hline Rescheduling & 0 & 0 & 0 & 0 & 0 & 0 & 0 \\
\hline \multicolumn{8}{|l|}{ Memorandum items: } \\
\hline Current account balance (in percent of GDP) & -1.5 & 0.0 & 1.3 & 2.6 & 0.2 & 0.9 & 0.5 \\
\hline Capital and financial account balance (in percent of GDP & 2.3 & 3.4 & 0.6 & 0.3 & 1.0 & 2.9 & -0.1 \\
\hline Export value (US\$), percent change & 17.8 & 38.8 & 36.7 & 37.7 & 6.2 & 9.4 & -1.0 \\
\hline Volume growth & 10.0 & 12.8 & 15.4 & 1.5 & 7.5 & 5.9 & 8.0 \\
\hline Price growth & 7.1 & 23.0 & 18.4 & 35.7 & -1.2 & 3.3 & -8.3 \\
\hline Import value (US\$), percent change & 11.2 & 19.0 & 23.0 & 23.3 & 16.1 & 20.2 & 12.7 \\
\hline Volume growth & 5.4 & 7.5 & 11.1 & 14.6 & 11.3 & 15.7 & 10.0 \\
\hline Price growth & 5.5 & 10.7 & 10.7 & 7.5 & 4.4 & 3.9 & 2.5 \\
\hline GDP (in billions of US\$) & 61.5 & 69.7 & 79.4 & 93.2 & 98.1 & 103.1 & 109.3 \\
\hline Average exchange rate (S/. per US\$) & 3.48 & 3.41 & 3.30 & 3.27 & 3.24 & 3.19 & 3.19 \\
\hline
\end{tabular}

Sources: Central Reserve Bank of Peru; Ministry of Economy and Finance; and Fund staff estimates/projections.

$1 /$ Includes debt swap operations.

2/ Includes portfolio flows of the pension reserve fund and subscription payments into international funds.

3/ Includes COFIDE and Banco de la Nación.

4/ Debt relief under existing operations. 
Table 11. Peru: External Financing Requirements and Sources

(In millions of U.S. dollars)

\begin{tabular}{|c|c|c|c|c|c|c|c|}
\hline & \multirow[b]{2}{*}{2003} & \multirow[b]{2}{*}{2004} & \multirow[b]{2}{*}{2005} & \multirow{2}{*}{$\begin{array}{l}\text { Prel. } \\
2006\end{array}$} & \multirow{2}{*}{$\begin{array}{l}\text { Prog. } \\
2007\end{array}$} & \multicolumn{2}{|c|}{ Projection } \\
\hline & & & & & & 2007 & 2008 \\
\hline Gross financing requirements & 6,008 & 7,125 & 8,440 & 5,265 & 5,459 & 9,855 & 5,076 \\
\hline $\begin{array}{l}\text { External current account deficit } \\
\text { (excluding official transfers) }\end{array}$ & 935 & 11 & $-1,033$ & $-2,456$ & -151 & -877 & -551 \\
\hline Debt amortization & 4,524 & 4,761 & 7,845 & 4,969 & 4,460 & 6,807 & 5,127 \\
\hline Medium- and long-term debt & 1,954 & 2,247 & 5,094 & 1,783 & 1,808 & 3,901 & 2,264 \\
\hline Public sector & 1,229 & 1,389 & 3,718 & 1,222 & 1,205 & 3,460 & 1,641 \\
\hline Multilateral 1/ & 486 & 571 & 628 & 647 & 707 & 705 & 696 \\
\hline Bilateral & 686 & 742 & 2,159 & 394 & 382 & 411 & 379 \\
\hline Bonds and notes & 44 & 67 & 90 & 90 & 113 & 2,340 & 544 \\
\hline Other & 13 & 9 & 842 & 92 & 4 & 4 & 22 \\
\hline Private sector & 725 & 858 & 1,376 & 561 & 602 & 441 & 623 \\
\hline Short-term debt $2 /$ & 2,570 & 2,514 & 2,751 & 3,186 & 2,652 & 2,906 & 2,863 \\
\hline Rescheduling and repayment of arrears & 72 & 0 & 0 & 0 & 0 & 0 & 0 \\
\hline Accumulation of NIR (flow) & 477 & 2,353 & 1,628 & 2,753 & 1,150 & 3,925 & 500 \\
\hline Change in gross reserves & 513 & 2,440 & 1,470 & 3,177 & 1,150 & 4,000 & 500 \\
\hline Payments of short-term liabilities incl. IMF & 84 & -3 & -4 & 1 & 0 & 0 & 0 \\
\hline Other & -119 & -84 & 162 & -425 & 0 & -75 & 0 \\
\hline Available financing & 6,008 & 7,125 & 8,440 & 5,265 & 5,459 & 9,855 & 5,076 \\
\hline Foreign direct investment (net) & 1,275 & 1,816 & 2,519 & 3,467 & 2,243 & 2,893 & 2,888 \\
\hline Privatization & 10 & 31 & 31 & 79 & 10 & 0 & 39 \\
\hline FDI & 1,265 & 1,785 & 2,489 & 3,388 & 2,233 & 2,893 & 2,849 \\
\hline Portfolio (net) & $-1,214$ & -376 & 75 & $-1,444$ & -910 & $-1,717$ & $-1,545$ \\
\hline Short-term assets (flow) & 870 & 102 & -209 & -940 & -390 & 1,438 & $-1,311$ \\
\hline Of which: Errors and omissions & 688 & 90 & 295 & -674 & 0 & 0 & 0 \\
\hline Debt financing from private creditors & 4,346 & 4,474 & 5,359 & 3,673 & 3,532 & 6,256 & 4,013 \\
\hline Medium- and long-term financing & 1,811 & 1,742 & 2,316 & 775 & 880 & 3,393 & 1,150 \\
\hline To public sector $3 /$ & 1,252 & 1,295 & 1,682 & 100 & 400 & 2,690 & 500 \\
\hline To private sector & 559 & 447 & 635 & 675 & 480 & 703 & 650 \\
\hline Short-term financing & 2,535 & 2,732 & 3,042 & 2,898 & 2,652 & 2,863 & 2,863 \\
\hline Official creditors 4/ & 909 & 1,240 & 974 & 608 & 1,005 & 999 & 1,089 \\
\hline Multilateral 1/ & 699 & 1,049 & 762 & 484 & 690 & 725 & 737 \\
\hline Of which: Balance of payments financing & 527 & 863 & 581 & 300 & 350 & 404 & 400 \\
\hline Bilateral & 210 & 191 & 212 & 123 & 315 & 274 & 287 \\
\hline To public sector & 210 & 191 & 212 & 123 & 315 & 274 & 287 \\
\hline To private sector & 0 & 0 & 0 & 0 & 0 & 0 & 0 \\
\hline Other medium- and long-term public sector flov & -178 & -131 & -278 & -98 & -22 & -15 & -58 \\
\hline IMF & 0 & 0 & 0 & 0 & 0 & 0 & 0 \\
\hline Accumulation of arrears (exceptional) & 0 & 0 & 0 & 0 & 0 & 0 & 0 \\
\hline
\end{tabular}

Sources: Central Reserve Bank of Peru; and Fund staff estimates/projections.

1/ Excluding IMF.

2/ Original maturity of less than one year. Equals stock at the end of the previous period.

$3 /$ Based on projections of no placements in external markets over the program period. Projections exclude possible external issuance for debt prepayments.

4/ Includes both loans and grants. Breakdown not available as of 2008. 
Table 12. Peru: Medium-Term Macroeconomic Framework

\begin{tabular}{|c|c|c|c|c|c|c|c|c|}
\hline & \multirow[b]{2}{*}{2005} & \multirow{2}{*}{$\begin{array}{l}\text { Prel. } \\
2006\end{array}$} & \multicolumn{6}{|c|}{ Staff Projection } \\
\hline & & & 2007 & 2008 & 2009 & 2010 & 2011 & 2012 \\
\hline \multicolumn{9}{|c|}{ (Annual percentage change) } \\
\hline GDP at constant prices & 6.4 & 8.0 & 7.0 & 6.0 & 5.5 & 5.5 & 5.5 & 5.5 \\
\hline Consumer prices (end of period) & 1.5 & 1.1 & 2.0 & 2.0 & 2.0 & 2.0 & 2.0 & 2.0 \\
\hline GDP deflator & 3.4 & 8.2 & 0.6 & 0.0 & 1.0 & 1.5 & 1.8 & 2.0 \\
\hline \multicolumn{9}{|l|}{ Merchandise trade } \\
\hline Exports, f.o.b. & 36.7 & 37.7 & 9.4 & -1.0 & 0.1 & 3.1 & 5.5 & 4.6 \\
\hline Imports, f.o.b. & 23.0 & 23.3 & 20.2 & 12.7 & 7.5 & 6.0 & 8.2 & 6.4 \\
\hline Terms of trade (deterioration -) & 5.9 & 26.1 & -0.6 & -10.5 & -7.6 & -4.7 & -1.1 & -0.9 \\
\hline \multicolumn{9}{|c|}{ (In percent of GDP; unless otherwise indicated) } \\
\hline External current account balance & 1.3 & 2.6 & 0.9 & 0.5 & 0.1 & -0.2 & -0.3 & -0.5 \\
\hline External current account, excluding interest obligations & 3.4 & 4.6 & 2.8 & 2.2 & 1.8 & 1.4 & 1.0 & 0.7 \\
\hline Total external debt service & 8.5 & 3.9 & 5.7 & 3.8 & 3.3 & 3.3 & 3.2 & 3.9 \\
\hline Medium- and long-term & 8.3 & 3.7 & 5.5 & 3.6 & 3.1 & 3.2 & 3.0 & 3.8 \\
\hline Nonfinancial public sector & 6.2 & 2.7 & 4.7 & 2.7 & 2.3 & 2.4 & 2.3 & 3.1 \\
\hline Private sector & 2.0 & 0.9 & 0.8 & 0.9 & 0.8 & 0.8 & 0.7 & 0.7 \\
\hline Short-term 1/ & 0.2 & 0.2 & 0.2 & 0.2 & 0.2 & 0.2 & 0.2 & 0.1 \\
\hline Nonfinancial public sector & 0.0 & 0.0 & 0.0 & 0.0 & 0.0 & 0.0 & 0.0 & 0.0 \\
\hline Private sector & 0.2 & 0.2 & 0.2 & 0.2 & 0.2 & 0.2 & 0.2 & 0.1 \\
\hline External debt service 2/ & 8.5 & 3.9 & 5.7 & 3.8 & 3.3 & 3.3 & 3.2 & 3.9 \\
\hline Interest & 2.1 & 2.0 & 1.9 & 1.7 & 1.7 & 1.5 & 1.4 & 1.2 \\
\hline Amortization (medium-and long-term) & 6.4 & 1.9 & 3.8 & 2.1 & 1.6 & 1.8 & 1.8 & 2.7 \\
\hline Combined public sector primary balance $3 /$ & 1.6 & 4.0 & 1.5 & 0.8 & 1.0 & 1.1 & 1.4 & 1.3 \\
\hline General government current revenue & 18.3 & 19.6 & 19.6 & 19.1 & 19.4 & 19.6 & 19.9 & 20.2 \\
\hline General govt. non-interest expenditure 3/ & 17.0 & 16.2 & 18.2 & 18.3 & 18.3 & 18.5 & 18.4 & 18.8 \\
\hline Combined public sector interest due & 1.9 & 1.9 & 1.8 & 1.7 & 1.6 & 1.6 & 1.5 & 1.4 \\
\hline Combined public sector overall balance $3 /$ & -0.3 & 2.1 & -0.3 & -0.9 & -0.7 & -0.5 & -0.1 & -0.1 \\
\hline Public sector debt $3 /$ & 37.7 & 32.7 & 30.0 & 28.8 & 27.4 & 25.7 & 23.7 & 21.8 \\
\hline Gross domestic investment & 18.6 & 21.0 & 22.5 & 24.3 & 25.2 & 25.7 & 26.0 & 26.8 \\
\hline Public sector $3 /$ & 2.9 & 2.8 & 4.8 & 5.2 & 5.5 & 5.8 & 5.9 & 6.4 \\
\hline Private sector & 16.0 & 16.8 & 18.0 & 18.8 & 19.4 & 19.8 & 20.1 & 20.3 \\
\hline Inventories changes & -0.2 & 1.3 & -0.3 & 0.4 & 0.3 & 0.1 & 0.0 & 0.0 \\
\hline National savings & 19.9 & 23.6 & 23.4 & 24.8 & 25.3 & 25.5 & 25.7 & 26.2 \\
\hline Public sector $4 /$ & 2.6 & 5.0 & 4.6 & 4.4 & 5.0 & 5.5 & 6.1 & 6.6 \\
\hline Private sector & 17.3 & 18.6 & 18.7 & 20.4 & 20.3 & 20.0 & 19.6 & 19.6 \\
\hline External savings & -1.3 & -2.6 & -0.9 & -0.5 & -0.1 & 0.2 & 0.3 & 0.5 \\
\hline \multicolumn{9}{|l|}{ Memorandum items: } \\
\hline Nominal GDP (billions of New Soles) & 261.6 & 305.8 & 329.2 & 349.0 & 371.8 & 398.2 & 427.6 & 460.2 \\
\hline Gross international reserves (billions of U.S. dollars) & 14,120 & 17,329 & 21,329 & 21,829 & 22,229 & 22,579 & 22,829 & 22,829 \\
\hline Gross international reserves to broad money & 73.1 & 74.4 & 80.6 & 75.0 & 71.2 & 68.3 & 65.8 & 63.1 \\
\hline External debt service (percent of exports of GNFS) & 34.8 & 14.0 & 20.6 & 14.7 & 13.6 & 14.3 & 13.9 & 17.7 \\
\hline Short-term external debt service (percent of exports of GNFS) & 0.8 & 0.8 & 0.7 & 0.7 & 0.7 & 0.7 & 0.7 & 0.7 \\
\hline Public external debt service (percent of exports of GNFS) & 25.5 & 9.7 & 17.1 & 10.5 & 9.4 & 10.3 & 10.0 & 14.0 \\
\hline
\end{tabular}

Sources: Central Reserve Bank of Peru; Ministry of Economy and Finance; and Fund staff estimates/projections.

$1 /$ Includes interest payments only.

2/ Includes the financial public sector.

3/ Includes CRPAOs.

4/ Excludes privatization receipts. 
Table 13. Peru: Financial and External Vulnerability Indicators

(In percent; unless otherwise indicated)

\begin{tabular}{|c|c|c|c|c|c|c|c|}
\hline & \multirow[b]{2}{*}{2003} & \multirow[b]{2}{*}{2004} & \multirow[b]{2}{*}{2005} & \multirow{2}{*}{$\begin{array}{l}\text { Prel. } \\
2006\end{array}$} & \multirow{2}{*}{$\begin{array}{l}\text { Prog. } \\
2007\end{array}$} & \multicolumn{2}{|c|}{ Projection } \\
\hline & & & & & & 2007 & 2008 \\
\hline \multicolumn{8}{|l|}{ Financial indicators } \\
\hline Public sector debt/GDP & 47.0 & 44.4 & 37.7 & 32.8 & 31.2 & 30.0 & 28.8 \\
\hline Of which: in domestic currency (percent of GDP) & 3.8 & 6.9 & 8.2 & 8.0 & 7.2 & 7.4 & 7.3 \\
\hline 90-day prime lending rate, domestic currency (end of period) & 3.3 & 3.8 & 4.4 & 5.2 & $\ldots$ & $\ldots$ & $\ldots$ \\
\hline 90-day prime lending rate, foreign currency (end of period) & 1.7 & 2.6 & 5.5 & 6.1 & $\ldots$ & $\ldots$ & $\ldots$ \\
\hline Velocity of money $1 /$ & 4.0 & 4.1 & 3.9 & 4.1 & 3.9 & 3.9 & 3.8 \\
\hline Net credit to the private sector/GDP 2/ & 29.3 & 27.7 & 28.0 & 28.7 & 27.3 & 30.3 & 31.2 \\
\hline \multicolumn{8}{|l|}{ External indicators } \\
\hline Exports, U.S. dollars (percent change) & 17.8 & 38.8 & 36.7 & 37.7 & 6.2 & 9.4 & -1.0 \\
\hline Imports, U.S. dollars (percent change) & 11.2 & 19.0 & 23.0 & 23.3 & 16.1 & 20.2 & 12.7 \\
\hline Terms of trade (percent change) (deterioration -) & 1.3 & 9.2 & 5.9 & 26.1 & -5.3 & -0.6 & -10.5 \\
\hline Real effective exchange rate, (end of period, percent change) $3 /$ & 3.8 & 1.6 & 0.5 & 1.3 & $\ldots$ & $\ldots$ & $\ldots$ \\
\hline Current account balance (percent of GDP) & -1.5 & 0.0 & 1.3 & 2.6 & 0.2 & 0.9 & 0.5 \\
\hline Capital and financial account balance (percent of GDP) & 2.3 & 3.4 & 0.6 & 0.3 & 1.0 & 2.9 & -0.1 \\
\hline Total external debt (percent of GDP) & 48.1 & 44.9 & 36.1 & 30.3 & 28.4 & 28.1 & 26.5 \\
\hline Medium- and long-term public debt (in percent of GDP) 4/ & 37.0 & 35.1 & 28.1 & 23.7 & 23.1 & 21.6 & 20.4 \\
\hline Medium- and long-term private debt (in percent of GDP) & 7.0 & 5.8 & 4.0 & 3.5 & 2.7 & 3.7 & 3.5 \\
\hline Short-term public and private debt (in percent of GDP) & 4.1 & 4.0 & 4.0 & 3.1 & 2.7 & 2.8 & 2.6 \\
\hline Total external debt (in percent of exports of goods and services) 4/ & 274.3 & 215.0 & 147.5 & 107.9 & 102.5 & 101.6 & 102.5 \\
\hline Total debt service (in percent of exports of goods and services) 5/ & 31.0 & 25.4 & 34.8 & 14.0 & 13.8 & 20.6 & 14.7 \\
\hline \multicolumn{8}{|l|}{ Gross official reserves } \\
\hline In millions of U.S. dollars & 10,206 & 12,649 & 14,120 & 17,329 & 16,765 & 21,329 & 21,829 \\
\hline In percent of short-term external debt $6 /$ & 211.9 & 166.3 & 311.4 & 356.6 & 336.9 & 412.6 & 458.3 \\
\hline \multicolumn{8}{|l|}{ In percent of short-term external debt, foreign currency deposits, and } \\
\hline adjusted CA balance $6 / 7 /$ & 70.2 & 73.5 & 92.0 & 104.7 & 98.7 & 118.9 & 121.4 \\
\hline In percent of broad money $8 /$ & 65.9 & 71.1 & 73.1 & 74.4 & 67.0 & 80.6 & 75.0 \\
\hline In percent of foreign currency deposits at banks & 105.2 & 131.9 & 130.6 & 148.2 & 139.6 & 167.0 & 165.2 \\
\hline In months of next year's imports of goods and services & 9.7 & 10.0 & 9.8 & 9.7 & 8.5 & 10.6 & 10.1 \\
\hline Net international reserves (in millions of U.S. dollars) & 10,194 & 12,631 & 14,097 & 17,275 & 16,747 & 21,275 & 21,775 \\
\hline Net international reserves (program definition; in millions of U.S. dollars) 9/ & 6,906 & 9,304 & 9,748 & 12,981 & 11,835 & $\ldots$ & $\ldots$ \\
\hline Net foreign exchange position (in millions of U.S. dollars) $10 /$ & 4,583 & 6,936 & 7,450 & 11,086 & 9,467 & 15,086 & 15,586 \\
\hline
\end{tabular}

Sources: Central Reserve Bank of Peru; and Fund staff estimates/ projections.

1/ Defined as the inverse of the ratio of end-period broad money to annual GDP.

2/ Corresponds to the financial system.

3/ End of period. Source: Information Notice System, IMF.

4/ Includes Central Reserve Bank of Peru debt.

$5 /$ Includes debt service to the Fund. For 2002, excludes US\$923 million of Brady bonds that were amortized in a debt exchange operation.

6/ Short-term debt includes amortization of medium- and long-term loans falling due over the following year, including debt swaps.

7/ Current Account deficit adjusted for $0.75^{\star}$ net FDI inflows; if adjusted CA balance>0, set to 0 .

8/ At end-period exchange rate.

9/ Includes financial system's foreign currency deposits in central bank as reserve liability.

10/ Includes public sector foreign currency deposits in central bank (e.g. pension reserve funds) as reserve liability. 
Table 14. Peru: Millennium Development Goals

\begin{tabular}{|c|c|c|c|c|c|c|c|c|}
\hline & 1995 & 2001 & 2002 & 2003 & 2004 & 2005 & 2006 & $\begin{array}{r}\text { Target } \\
2015\end{array}$ \\
\hline \multicolumn{9}{|l|}{ Goal 1: Eradicate extreme poverty and hunger } \\
\hline Population below $\$ 1$ a day (in percent of population) & $\ldots$ & 18.1 & 12.8 & 10.5 & $\ldots$ & $\ldots$ & $\ldots$ & 9.1 \\
\hline Poverty gap at $\$ 1$ a day (in percent of total population,) & $\ldots$ & 9.1 & 4.4 & 2.9 & $\ldots$ & $\ldots$ & $\ldots$ & 4.6 \\
\hline Percent of income or consumption held by poorest 20 percent & $\ldots$ & 2.9 & 3.1 & 3.7 & $\ldots$ & $\ldots$ & $\ldots$ & 1.5 \\
\hline Prevalence of child malnutrition (in percent of children under 5) & 7.8 & 7.1 & $\ldots$ & $\ldots$ & $\ldots$ & $\ldots$ & $\ldots$ & 5.4 \\
\hline Pop. below min. of dietary energy consumption (in percent of total) & 18.0 & 11.0 & 13.0 & 12.0 & $\ldots$ & $\ldots$ & $\ldots$ & 20.0 \\
\hline \multicolumn{9}{|l|}{ Goal 2: Achieve universal primary education } \\
\hline Net primary enrollment ratio (in percent of relevant age group) & 90.8 & 97.9 & 97.9 & 97.3 & 97.1 & $\ldots$ & $\ldots$ & 100.0 \\
\hline Percentage of cohort reaching grade 5 (in percent) & $\ldots$ & 87.4 & $\ldots$ & 89.7 & $\ldots$ & $\ldots$ & $\ldots$ & 100.0 \\
\hline Youth literacy rate (in percent of ages 15-24) & 95.7 & 96.9 & 96.8 & $\ldots$ & 97.0 & $\ldots$ & $\ldots$ & 100.0 \\
\hline \multicolumn{9}{|l|}{ Goal 3: Promote gender equality and empower women } \\
\hline Ratio of girls to boys in primary and secondary education (in percent) & 96.0 & 97.0 & 97.1 & 99.8 & 100.0 & $\ldots$ & $\ldots$ & 100.0 \\
\hline Ratio of young literate females to males (in percent of ages 15-24) & 96.0 & 97.1 & 97.8 & 97.8 & 97.8 & $\ldots$ & 97.8 & 100.0 \\
\hline Share of women employed in the nonagricultural sector (in percent) & 30.5 & 34.6 & 35.0 & 37.2 & 34.6 & $\ldots$ & $\ldots$ & $\ldots$ \\
\hline Proportion of seats held by women in national parliament (in percent) & 10.0 & 20.0 & 18.0 & 18.0 & 18.0 & 18.3 & 29.2 & $\ldots$ \\
\hline \multicolumn{9}{|l|}{ Goal 4: Reduce child mortality } \\
\hline Under 5 mortality rate (per 1,000$)$ & 60.0 & 42.0 & 39.0 & 34.0 & 29.2 & 22.8 & $\ldots$ & 53.3 \\
\hline Infant mortality rate (per 1,000 live births) & 46.0 & 40.0 & 30.0 & 26.0 & 24.2 & 27.3 & $\ldots$ & $\ldots$ \\
\hline Immunization, measles (in percent of children under 12 months) & 98.0 & 97.0 & 95.0 & 95.0 & 89.0 & 80.0 & $\ldots$ & $\ldots$ \\
\hline \multicolumn{9}{|l|}{ Goal 5: Improve maternal health } \\
\hline Maternal mortality ratio (modeled estimate, per 100,000 live births) & $\ldots$ & 410.0 & $\ldots$ & $\ldots$ & $\ldots$ & $\ldots$ & $\ldots$ & 307.5 \\
\hline Births attended by skilled health staff (in percent of total) & 56.4 & 59.3 & $\cdots$ & $\cdots$ & 73.4 & $\cdots$ & $\cdots$ & $\cdots$ \\
\hline \multicolumn{9}{|l|}{ Goal 6: Combat HIVIAIDS, malaria and other diseases } \\
\hline Prevalence of HIV, total (in percent of ages 15-24) & $\ldots$ & 0.2 & 0.2 & 0.5 & .. & 0.6 & $\ldots$ & 0.1 \\
\hline Contraceptive prevalence rate (in percent of women ages 15-49) & 64.0 & 68.9 & $\ldots$ & $\ldots$ & $\ldots$ & $\ldots$ & $\ldots$ & $\ldots$ \\
\hline Number of children orphaned by HIVIAIDS & $\ldots$ & 17000 & $\ldots$ & $\ldots$ & $\ldots$ & $\ldots$ & $\ldots$ & $\ldots$ \\
\hline Incidence of tuberculosis (per 100,000 people) & 196.7 & 196.0 & 202.4 & 187.6 & 178.4 & 171.5 & $\ldots$ & $\ldots$ \\
\hline Tuberculosis cases detected under DOTS & 99.0 & 94.0 & 84.5 & 80.6 & 83.1 & 86.0 & $\cdots$ & $\cdots$ \\
\hline \multicolumn{9}{|l|}{ Goal 7: Ensure environmental sustainability } \\
\hline Forest area (in percent of total land area) & $\ldots$ & 50.9 & $\ldots$ & $\ldots$ & $\ldots$ & 53.7 & $\ldots$ & $\ldots$ \\
\hline Nationally protected areas (in percent of total land area) & 2.7 & 2.7 & 6.1 & 6.1 & $\ldots$ & $\ldots$ & $\ldots$ & $\ldots$ \\
\hline GDP per unit of energy use (PPP \$ per kg oil equivalent) & 8.9 & 10.4 & 10.7 & 11.0 & 10.9 & $\ldots$ & $\ldots$ & $\ldots$ \\
\hline CO2 emissions (metric tons per capita) & 1.0 & 1.1 & $\ldots$ & 1.0 & $\ldots$ & $\ldots$ & $\ldots$ & $\ldots$ \\
\hline Access to an improved water source (in percent of total population) & $\ldots$ & 80.0 & 81.0 & 83.0 & 83.0 & $\ldots$ & $\ldots$ & 87.0 \\
\hline Access to improved sanitation (in percent of total population) & $\ldots$ & 71.0 & 62.0 & 63.0 & 63.0 & $\ldots$ & $\ldots$ & $\ldots$ \\
\hline Access to secure tenure (in percent of total population) & $\cdots$ & $\cdots$ & $\cdots$ & $\cdots$ & $\ldots$ & $\cdots$ & $\cdots$ & $\cdots$ \\
\hline \multicolumn{9}{|l|}{ Goal 8: Develop a Global Partnership for Development } \\
\hline Youth unemployment rate (in percent of labor force ages 15-24) & 11.4 & 13.2 & 15.2 & 19.2 & 19.1 & 20.9 & $\cdots$ & $\cdots$ \\
\hline Fixed line and mobile telephones (per 1,000 people) & 50.3 & 136.7 & 152.3 & 175.6 & 222.9 & 280.1 & $\ldots$ & $\ldots$ \\
\hline Personal computers (per 1,000 people) & 14.9 & 47.9 & 43.0 & 64.7 & 97.6 & 100.1 & $\ldots$ & ... \\
\hline
\end{tabular}


Table 15. Peru: Proposed Schedule of Purchases Under the Stand-By Arrangement, 2007-09 1/

\begin{tabular}{|c|c|c|}
\hline Amount of Purchase & Availability Date & Conditions Include \\
\hline 1. SDR 159.6 million 2/ & January 26, 2007 & Board approval of SBA. \\
\hline 2. SDR 1.596 million & June 27, 2007 & $\begin{array}{l}\text { Completion of the First Review and observance of end-March } \\
2007 \text { performance criteria. }\end{array}$ \\
\hline 3. SDR 1.596 million & August 15, 2007 & Observance of end-June 2007 performance criteria. \\
\hline 4. SDR 1.596 million & November 15, 2007 & $\begin{array}{l}\text { Completion of the Second Review and observance of end- } \\
\text { September } 2007 \text { performance criteria. }\end{array}$ \\
\hline 5. SDR 1.596 million & February 15, 2008 & Observance of end-December 2007 performance criteria. \\
\hline 6. SDR 1.596 million & May 15, 2008 & $\begin{array}{l}\text { Completion of the Third Review and observance of end-March } \\
2008 \text { performance criteria. }\end{array}$ \\
\hline 7. SDR 1.596 million & August 15, 2008 & Observance of end-June 2008 performance criteria. \\
\hline 8. SDR 1.596 million & November 15, 2008 & $\begin{array}{l}\text { Completion of the Fourth Review and observance end-September } \\
2008 \text { performance criteria. }\end{array}$ \\
\hline 9. SDR 1.596 million & February 15, 2009 & Observance of end-December 2008 performance criteria. \\
\hline
\end{tabular}

1/ Total access under the Stand-By Arrangement is SDR 172.4 million (27 percent of quota).

$2 /$ This amount is required to exhaust the first credit tranche which is not subject to phasing. 
Table 16. Peru: Capacity to Repay the Fund as of March 29, 2007 1/ (In millions of SDRs; unless otherwise indicated)

\begin{tabular}{|c|c|c|c|c|c|c|c|c|c|}
\hline & 2007 & 2008 & 2009 & 2010 & 2011 & 2012 & 2013 & 2014 & Tota \\
\hline \multicolumn{10}{|l|}{ Obligations from existing drawings } \\
\hline Principal (repurchases) & 0.0 & 0.0 & 0.0 & 0.0 & 0.0 & 0.0 & 0.0 & 0.0 & 0.0 \\
\hline \multicolumn{10}{|l|}{ Charges and interest } \\
\hline GRA charges & 0.0 & 0.0 & 0.0 & 0.0 & 0.0 & 0.0 & 0.0 & 0.0 & 0.0 \\
\hline SDR charges & 2.9 & 3.7 & 3.7 & 3.7 & 3.7 & 3.7 & 3.7 & 3.7 & 28.6 \\
\hline Credit outstanding & 0.0 & 0.0 & 0.0 & 0.0 & 0.0 & 0.0 & 0.0 & 0.0 & ... \\
\hline (percent of quota) & 0.0 & 0.0 & 0.0 & 0.0 & 0.0 & 0.0 & 0.0 & 0.0 & ... \\
\hline \multicolumn{10}{|l|}{ Obligations from prospective drawings } \\
\hline Principal (repurchases) & 0.0 & 0.0 & 0.0 & 20.4 & 83.4 & 65.6 & 2.8 & 0.2 & 172.4 \\
\hline \multicolumn{10}{|l|}{ Charges and interest $2 /$} \\
\hline GRA charges & 2.5 & 9.1 & 9.4 & 9.4 & 6.5 & 1.9 & 0.1 & 0.0 & 38.8 \\
\hline Service and commitment charges & 0.8 & 0.0 & 0.0 & 0.0 & 0.0 & 0.0 & 0.0 & 0.0 & 0.9 \\
\hline Credit outstanding & 164.4 & 170.8 & 172.4 & 152.0 & 68.6 & 3.0 & 0.2 & 0.0 & ... \\
\hline (percent of quota) & 25.8 & 26.8 & 27.0 & 23.8 & 10.8 & 0.5 & 0.0 & 0.0 & ... \\
\hline \multicolumn{10}{|l|}{ Cumulative (existing and prospective) } \\
\hline Principal (repurchases) & 0.0 & 0.0 & 0.0 & 20.4 & 83.4 & 65.6 & 2.8 & 0.2 & 172.4 \\
\hline \multicolumn{10}{|l|}{ Charges and interest 2/ } \\
\hline GRA charges & 2.5 & 9.1 & 9.4 & 9.4 & 6.5 & 1.9 & 0.1 & 0.0 & 38.8 \\
\hline SDR and Service charges & 3.7 & 3.7 & 3.7 & 3.7 & 3.7 & 3.7 & 3.7 & 3.7 & 29.4 \\
\hline Credit outstanding & 164.4 & 170.8 & 172.4 & 152.0 & 68.6 & 3.0 & 0.2 & 0.0 & ... \\
\hline Percent of quota & 25.8 & 26.8 & 27.0 & 23.8 & 10.8 & 0.5 & 0.0 & 0.0 & .. \\
\hline Percent of GDP & 0.2 & 0.2 & 0.2 & 0.2 & 0.1 & 0.0 & 0.0 & 0.0 & ... \\
\hline Percent of exports of goods and services & 0.9 & 0.9 & 0.9 & 0.8 & 0.3 & 0.0 & 0.0 & 0.0 & ... \\
\hline Percent of public sector debt service & 6.9 & 6.4 & 7.7 & 6.0 & 3.7 & 0.1 & 0.0 & 0.0 & ... \\
\hline Percent of external public debt & 1.1 & 1.2 & 1.1 & 1.0 & 0.5 & 0.0 & 0.0 & 0.0 & ... \\
\hline Percent of external public debt service & 9.6 & 8.8 & 10.8 & 8.5 & 3.8 & 0.1 & 0.0 & 0.0 & ... \\
\hline Percent of gross foreign reserves & 1.5 & 1.2 & 1.2 & 1.0 & 0.5 & 0.0 & 0.0 & 0.0 & ... \\
\hline \multicolumn{10}{|l|}{ Memorandum item: } \\
\hline Purchases & 164.4 & 6.4 & 1.6 & 0.0 & 0.0 & 0.0 & 0.0 & 0.0 & 172.4 \\
\hline
\end{tabular}

Sources: Fund staff estimates/projections.

1/ Assuming all purchases are made. Repurchases assumed to be made under obligations schedule.

2/ Projections are based on current rates of charge, including burden-sharing charges where applicable, for purchases in the GRA. The current SDR interest rate is assumed for net use of SDRs. 


\section{Appendix 1. Peru: DebT Sustainability Analysis ${ }^{1}$}

Peru's debt-to-GDP ratio is projected to decline significantly under the baseline debt sustainability scenario. Economic growth would average about $5 \frac{1}{2}$ percent a year with the overall deficit of the combined public sector averaging $1 / 2$ percent of GDP. Public sector revenue would increase by 1 percent of GDP during 2007-2012. Under these assumptions, Peru's public sector debt stock would decline from 33 percent of GDP at end-2006, to about 22 percent of GDP by 2012.

Given that nearly 80 percent of total external debt is public, in the baseline scenario the projected drop in public debt largely determines the path of Peru's total external debt. Following a decline during 2004-05, as companies took advantage of favorable market conditions to pay down their external debt, private sector external debt is projected to decline slightly over the medium term, from already low levels. As a result, total external debt is projected to decline from 30 percent of GDP at end-2006 to 20 percent by 2012 (public external debt would decline from 24 percent to 17 percent over the same period).

Peru's external and public sector debt ratios are robust to alternative assumptions about underlying macroeconomic variables. Sensitivity tests based on 10-year historical standard deviations to form alternative medium-term assumptions for real GDP growth and interest rates show that Peru's debt dynamics are only moderately vulnerable to such changes.

In contrast, external and public debt ratios are sensitive to changes in exchange rate changes, given the high foreign currency share of Peru's debt. Specifically, under a one-off 30 percent depreciation of the exchange rate, the external debt-to-GDP ratio would shift by about 11 percentage points above the baseline projections in the medium term. This test assumes that the exchange rate would remain at its depreciated level permanently - a scenario that could only occur in case of the current exchange rate being significantly overvalued. Available data, however, do not point to such an overvaluation. Non-interest current account shocks (such as in the terms of trade) would have a moderate adverse impact on external indebtedness.

A similar pattern is observed under a 10 percent of GDP shock to the contingent liabilities of the public sector: The public debt-to-GDP ratio would rise sharply in the short run and, while declining over the medium term, would remain 9 percentage points above the debt levels projected under the baseline scenario.

\footnotetext{
${ }^{1}$ The DSA includes standard sensitivity tests around the baseline medium-term scenario.
} 
Figure 1. Peru: External Debt Sustainability: Bound Tests 1/ (External debt in percent of GDP)
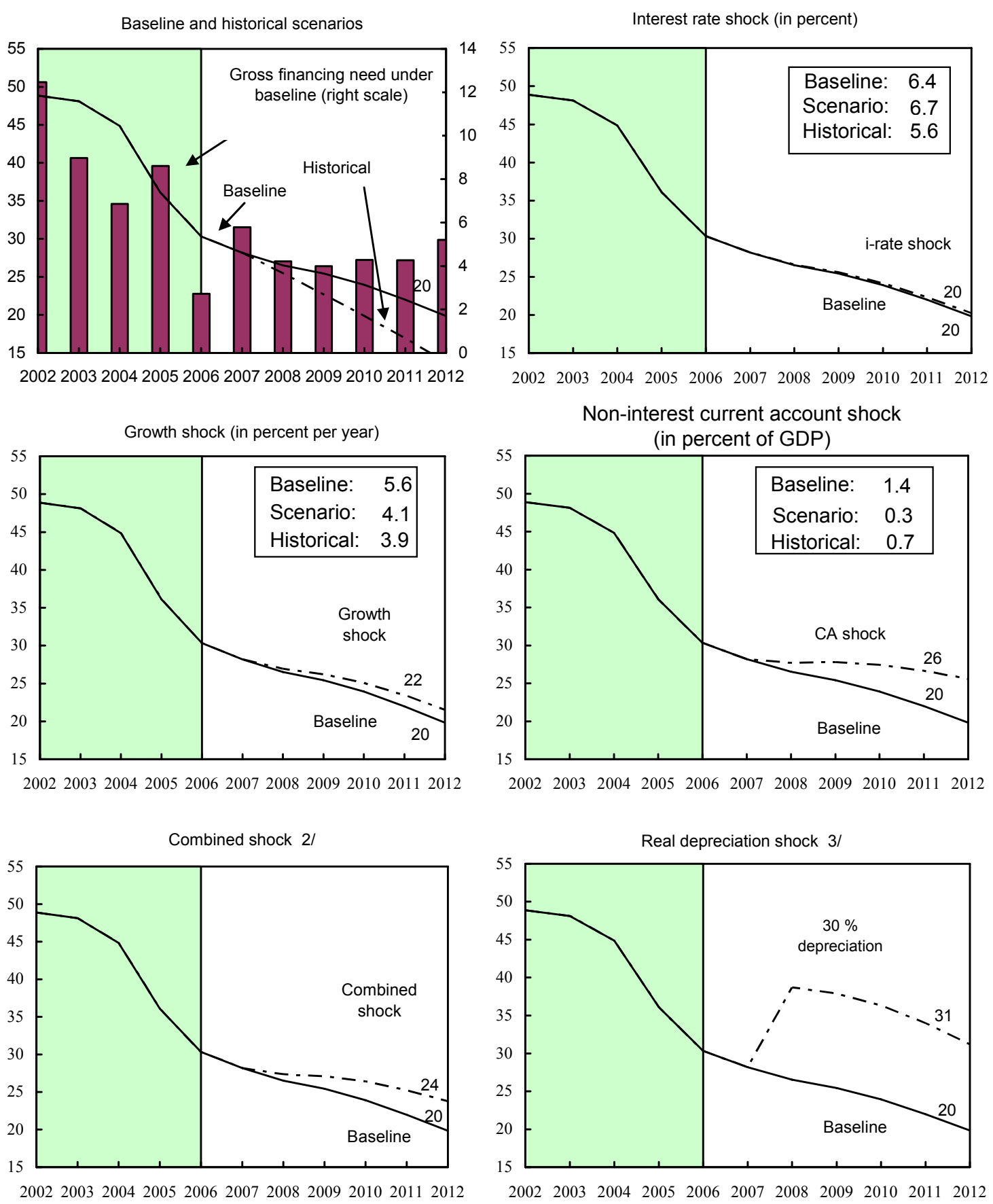

Sources: International Monetary Fund, Country desk data, and staff estimates. $1 /$ Shaded areas represent actual data. Individual shocks are permanent one-half standard deviation shocks. Figures in the boxes represent average projections for the respective variables in the baseline and scenario being presented. Ten-year historical average for the variable is also shown. 2/ Permanent 1/4 standard deviation shocks applied to real interest rate, growth rate, and current account balance.

3/ One-time real depreciation of 30 percent occurs in 2006. 
Figure 2. Country: Public Debt Sustainability: Bound Tests 1/ (Public debt in percent of GDP)
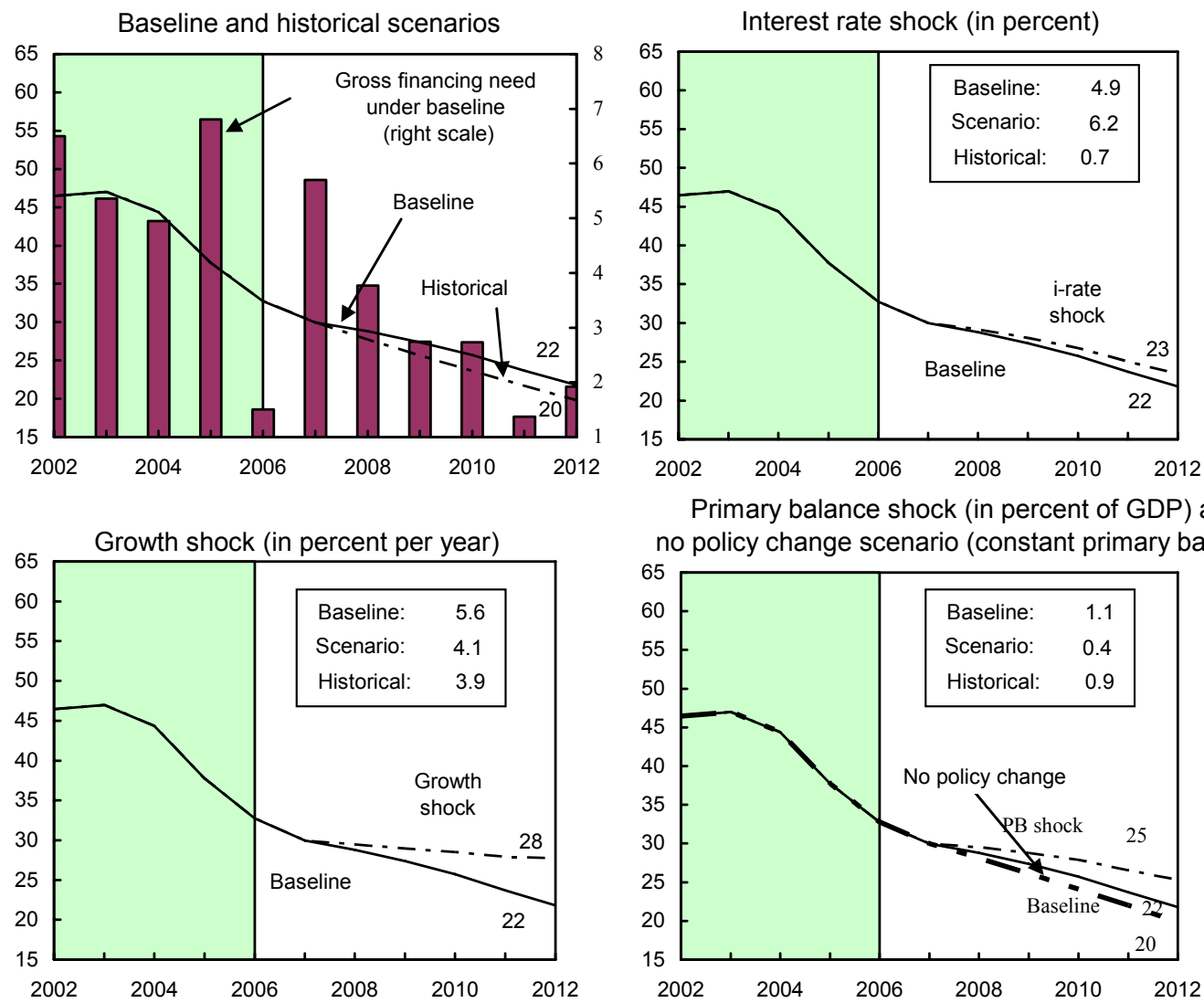

Primary balance shock (in percent of GDP) and no policy change scenario (constant primary balance)

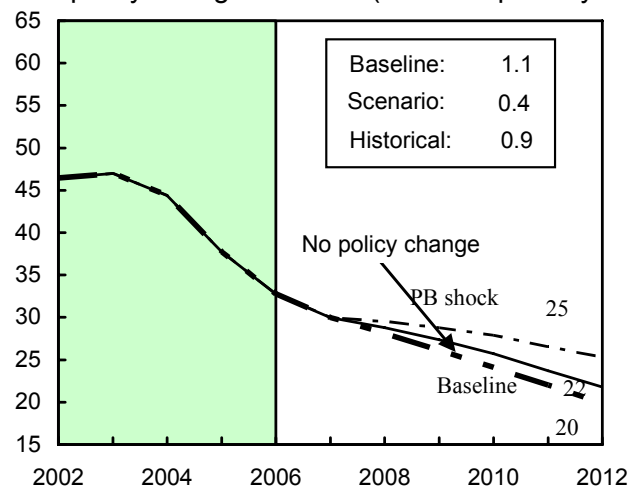

Combined shock 2/

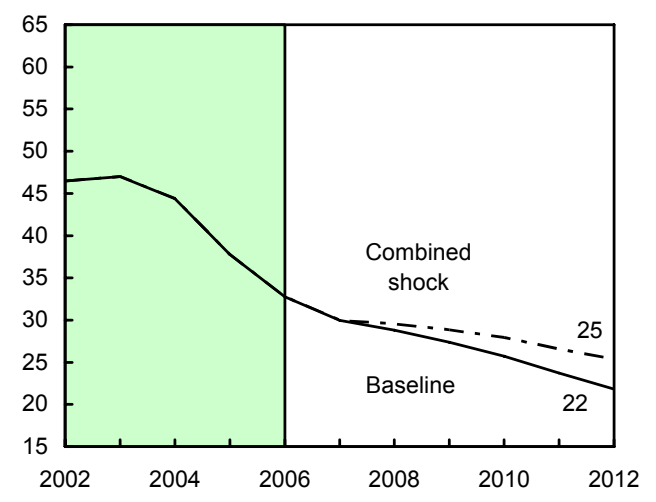

Real depreciation and contingent liabilities shocks 3/

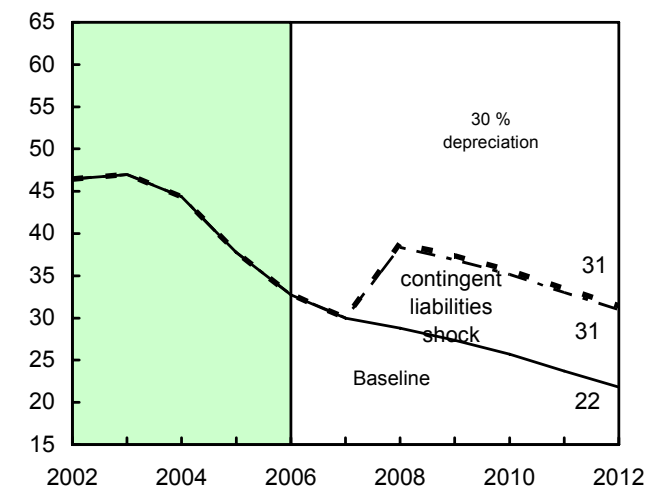

Sources: International Monetary Fund, country desk data, and staff estimates.

1/ Shaded areas represent actual data. Individual shocks are permanent one-half standard deviation shocks. Figures in the boxes represent average projections for the respective variables in the baseline and scenario being presented. Ten-year historical average for the variable is also shown. 2/ Permanent 1/4 standard deviation shocks applied to real interest rate, growth rate, and primary balance.

3/ One-time real depreciation of 30 percent and 10 percent of GDP shock to contingent liabilities occur in 2008 , with real depreciation defined as nominal depreciation (measured by percentage fall in dollar value of local currency) minus domestic inflation (based on GDP deflator). 


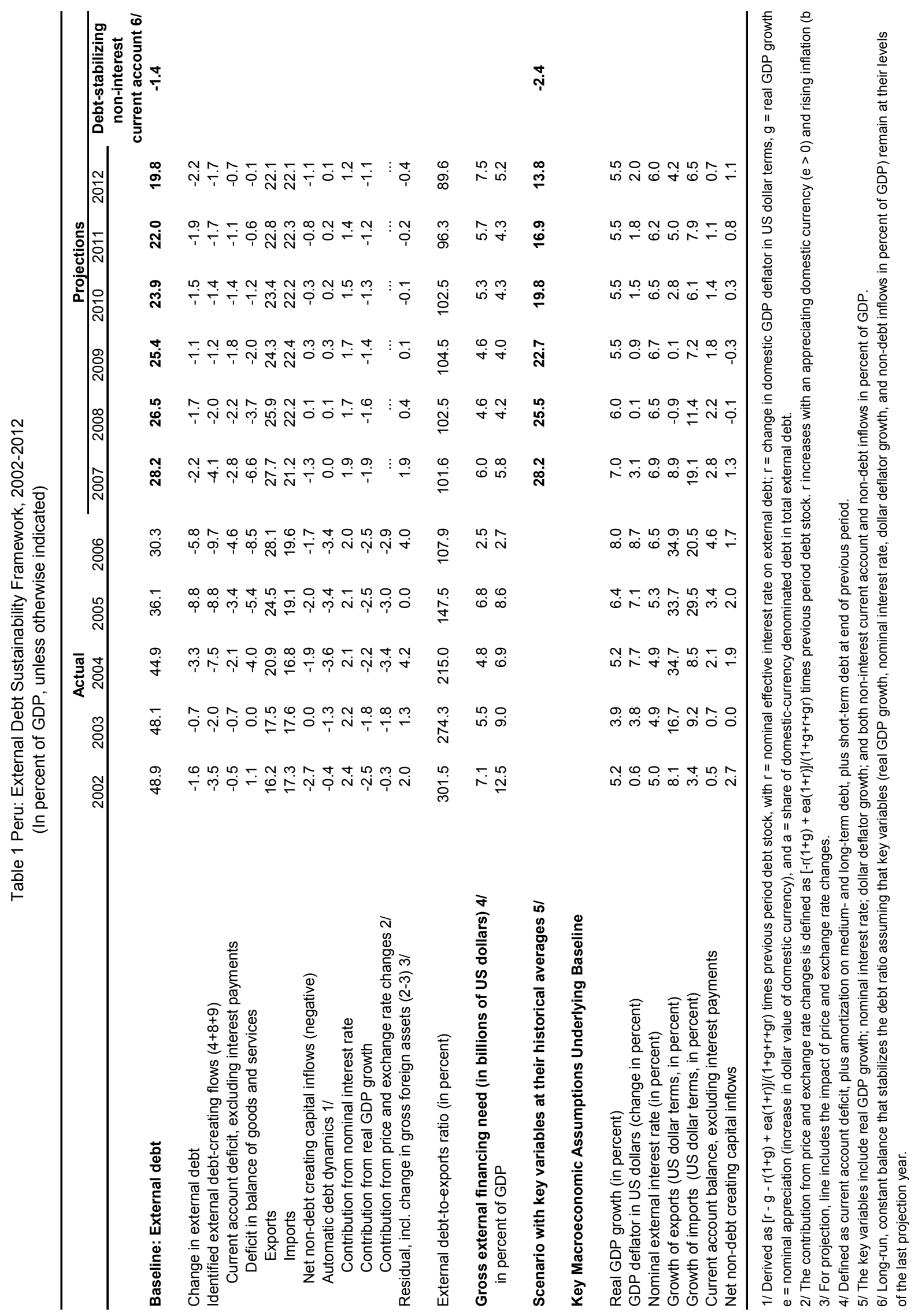




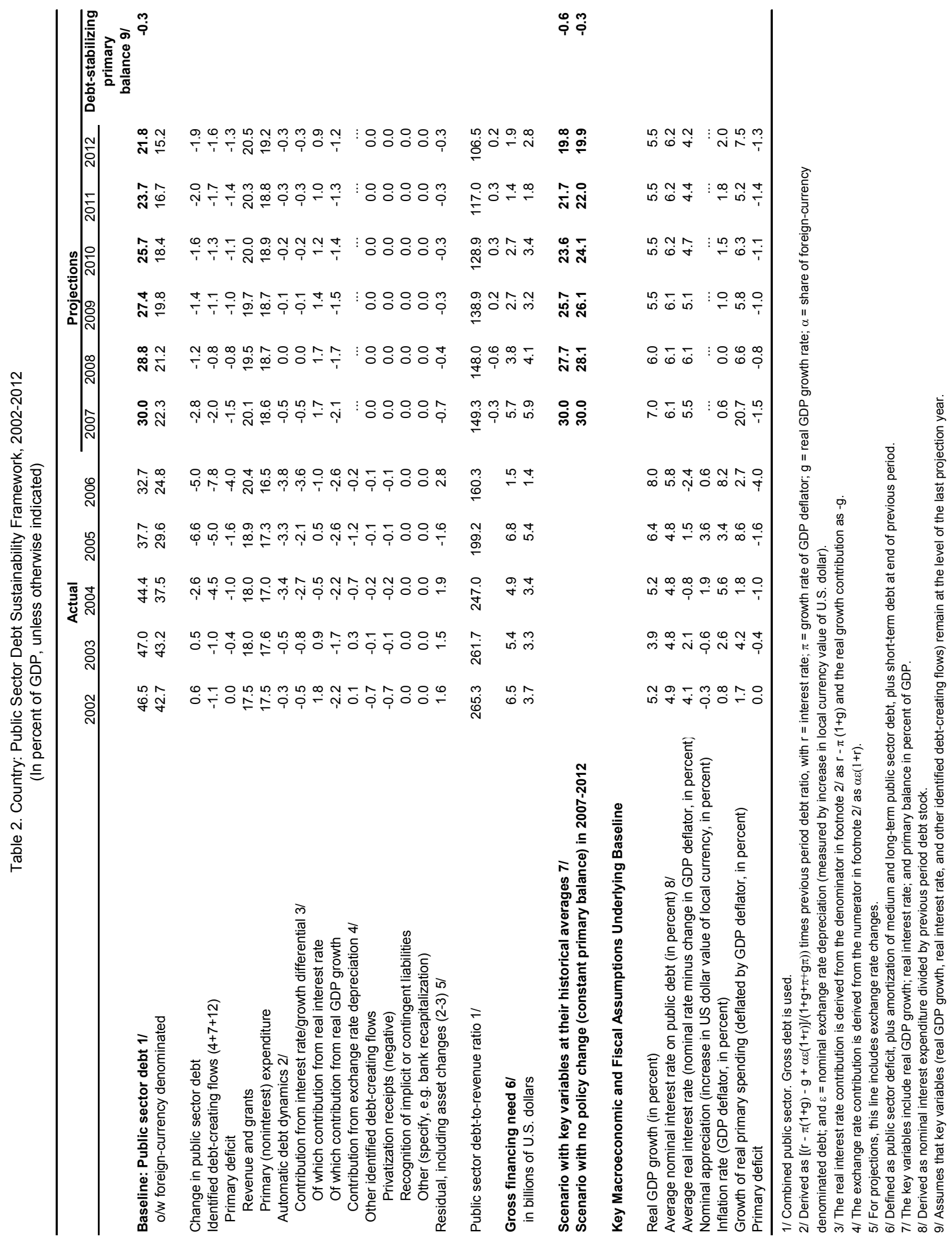




\section{AnNex 1. Peru: Fund Relations}

(As of April 30, 2006)

I. Membership Status: Joined 12/31/1945; accepted Article VIII obligations on February 15, 1961.

II. General Resources Account

Quota

Fund holdings of currency

III. SDR Department

Net cumulative allocation

Holdings
SDR Million

638.40

638.43

SDR Million

91.32

2.58

None

\section{Outstanding Purchases and Loans}

Percent Quota
100.00
100.01

Percent Allocation

100.00

2.82

\section{Financial Arrangements}

Amount

$\begin{array}{cc}\text { Approval } & \text { Expiration } \\ \text { Date } & \text { Date }\end{array}$

Type of Arrangement

Stand-By

Stand-By

Stand-By

$\begin{array}{ll}1 / 26 / 07 & 2 / 25 / 09 \\ 6 / 09 / 04 & 8 / 16 / 06 \\ 2 / 01 / 02 & 2 / 29 / 04\end{array}$

Approved (SDR Million)

172.37

287.28

255.00

\section{Amount Drawn (SDR Million)}
0.00
0.00
0.00

VI. Projected Obligations to the Fund (SDR Million; based on existing use of resources and present holdings of SDRs):

\begin{tabular}{lllll}
$\mathbf{2 0 0 7}$ & $\mathbf{2 0 0 8}$ & $\mathbf{2 0 0 9}$ & $\mathbf{2 0 1 0}$ & $\mathbf{2 0 1 1}$ \\
\hline & & & & \\
2.85 & 3.76 & 3.76 & 3.76 & 3.76 \\
2.85 & 3.76 & 3.76 & 3.76 & 3.76
\end{tabular}

\section{Safeguards Assessments}

An off-site safeguards assessment of the central bank is being finalized and has found that safeguards at the Banco Central de Reserva del Perú (BCRP) meet the requirements of the safeguards policy.

\section{Exchange Arrangements}

Peru maintains a unified, managed floating exchange rate. On April 30, 2007, the average of interbank buying and selling rates was 3.17 Nuevo Sol per U.S. dollar. The exchange system is free of restrictions, except for those maintained solely for the preservation of national or international security, and which have been notified to the Fund pursuant to Executive Board Decision No. 144(52/51). Those restrictions are maintain pursuant to UN Security Council Resolutions 1267 (October 15, 1999) and 1373 (September 28, 2001). The central government maintains external payments arrears to unguaranteed suppliers, some of whom are in discussions with the government, while the rest have not been located. Peru has maintained a clearing arrangement with Malaysia since 1991. 


\section{Last Article IV Consultation}

The 2006 Article IV consultation was concluded on January 26, 2007 (Country Report No. 07/54).

\section{FSAP and ROSCs}

Several joint Fund-Bank missions visited Lima in the period September 2000-January 2001 to conduct an FSAP for Peru. The corresponding FSSA report was discussed by the Executive Board on March 12, 2001. A follow-up FSAP mission was concluded in February 2005. In October 2002, an FAD mission conducted a Fiscal ROSC for Peru, while an STA mission conducted a Data ROSC for Peru in February 2003.

\section{Technical Assistance}

$\begin{array}{lll}\text { Department } & \text { Date } & \text { Purpose } \\ \text { FAD } & \begin{array}{l}\text { June 2005, March 2006, } \\ \text { November 2006 }\end{array} & \text { Public Financial Management } \\ & \begin{array}{l}\text { May 2005, February, } \\ \text { September, and November } \\ \text { 2006, February 2007 }\end{array} & \text { Tax policy and administration } \\ \text { September 2003 } & \\ \text { September 2002 } & \\ \text { August 2004 } & \\ & \text { November 1999 } & \\ \text { April 2006 } & \text { Public investment and fiscal policy, including } \\ \text { April 2005 } & \text { issues related to PPPs. } \\ \text { March, 2005 } & \text { Fiscal rules } \\ \text { March, September 2004 } & \text { Financial sector supervision } \\ \text { February 2003 } & \text { Consumer protection in the banking system } \\ \text { April, December 2002 } & \text { Central bank organization } \\ \text { October 2002 } & \\ \text { August 2002 } & \text { Inflation targeting } \\ \text { May 2002 } & \text { Foreign exchange operations } \\ \text { March 2002 } & \text { Accounting and organizational issues } \\ \text { January 1998 and } & \text { Inflation targeting } \\ \text { October 1999 } & \text { Monetary operations and government securities } \\ \text { market }\end{array}$

\section{Resident Representative}

Ms. Nicoletta Batini has been Resident Representative in Peru since January 2006. 


\section{ANNEX 2. Peru: World BANK Relations}

\section{Bank Group strategy}

A World Bank Group Country Partnership Strategy (CPS) was approved by the Board on December 19, 2006. The strategy has been designed to support the government's poverty reduction agenda with programs addressing fiscal, national competitiveness, and socialsector needs. The program supported by the Bank emphasizes partnerships, flexibility and results orientation in public expenditure. The new CPS projects financial assistance of up to US $\$ 3.5$ billion between July 2007 and June 2011 and envisages a lending program that will include a combination of two fast disbursing loans and three investment projects per fiscal year. The strategy includes development policy lending operations in the fiscal and social sectors, and possibly one to support policy reforms in the environmental sector.

The ongoing investment portfolio consists of 17 operations for a net commitment of \$536 million and one Guarantee Facility for US\$200 million. Two development policy loans (DPLs) have been approved in FY07: the Fiscal Management and Competitiveness DPL and the Results and Accountability DPL, in the amount of \$200 and US\$150 million respectively. In addition, two investment loans have been approved in FY07, including the Sierra Rural Development project for $\$ 20$ million and the Decentralized Rural Transport project for $\$ 50$ million. The FY08 pipeline comprises 7 operations for a commitment amount of approximately $\$ 400$ million. Bank support has and will continue to focus on three areas: (i) strengthening public sector management and decentralization; (iii) maintaining macro stability and accelerating growth; and (iii) fostering equity and quality of social services, particularly in rural areas.

\section{Bank-Fund collaboration in specific areas}

- $\quad$ Tax Reform and Fiscal Decentralization. Fund staff has taken the lead in assisting in the design of tax reform. Jointly with the World Bank and IDB, staff has worked on drafting laws and regulations for fiscal decentralization. The World Bank has also focused on the design and implementation of decentralization of the social sectors and pro-poor spending policies.

- $\quad$ Financial Sector. A joint FSAP was completed in May 2001. Follow up technical assistance to implement FSAP recommendations has been given by both institutions. A joint FSAP update was completed in June 2005.

- $\quad$ Fiscal Management. A joint IMF-World Bank-IDB mission took place in September 2004 for a pilot study on Public Investment and Fiscal Policy. Most recently, BankFund collaboration has focused in the area of results budgeting, the implementation of a Treasury Single Account and other issues related to financial management. 
- $\quad$ Country Partnership Strategy preparation and design of Programmatic Loans (i.e. first Programmatic Fiscal Management and Competitiveness DPL). Dialogue has concentrated on the evaluation of the macroeconomic framework, the program supported under the DPL, including the setting of triggers, and risks and estimation of the fiscal implications of policy programs under Bank operations.

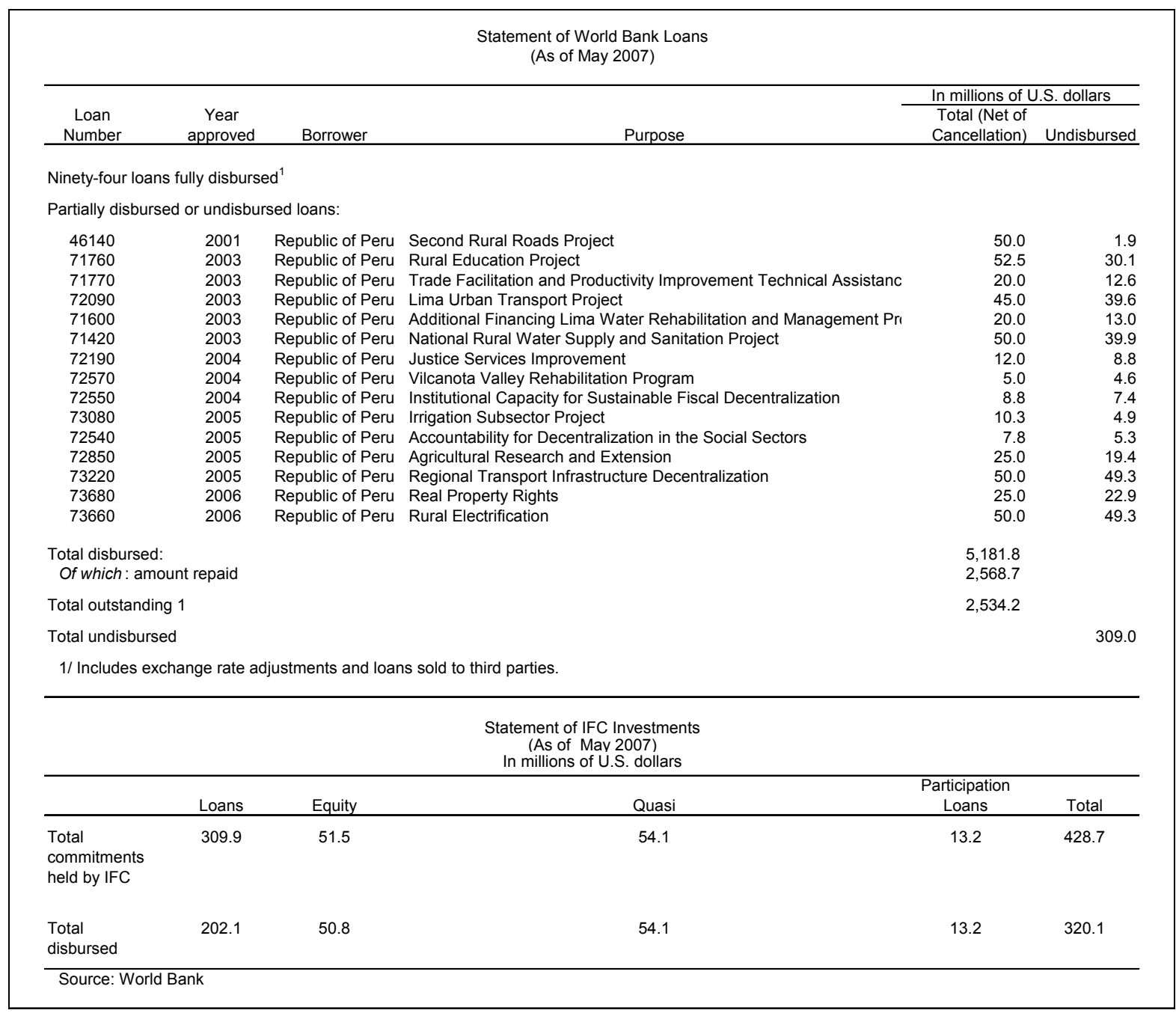




\section{ANNeX 3. Peru: Relations With the INTER-American DeVElopment Bank}

\section{Country Strategy}

The key objectives of the 2002-2006 strategy for Peru are poverty reduction and equity promotion, within a context of high economic growth needed to make these goals sustainable. Toward this end, the Bank supports government's efforts to: (i) raise economic productivity and competitiveness; (ii) improve the efficiency of social policy while implementing measures to mitigate poverty and protect vulnerable groups; and (iii) create a modern, decentralized and efficient state.

The Bank and the authorities have started the dialogue for the preparation of the new strategy for 2007-2011, which is projected for approval in August.

\section{Lending}

As of June $6^{\text {th }}, 2007$, the country's active portfolio consists of 26 loans for a total amount of US\$1,230.5 million. These resources are distributed among 25 investment loans (US\$930.5 million) and one policy-based loan (US\$300.0 million).

The lending program for 2007 comprises seven investment loans for US\$124.5 million and three programmatic loans for US\$600.0 million. A high-case scenario forecasts total 2007 disbursements at US\$874.9 million, of which US\$750.0 is for policy-based lending.

To assist government efforts to de-dollarize the public sector debt, negotiations are currently underway to convert US\$200.0 million of a previously disbursed loan into local currency.

The Private Sector Department (PRI) is completing due diligence on the Peru - Liquefied Natural Gas project for US\$400.0 million, expected to be approved in the second quarter 2008.

Finally, the Bank's portfolio with Peru includes non-reimbursable technical cooperation totaling US\$28.3 million.

IDB Loan Portfolio by Sector, as of June $6^{\text {th }}, 2007$ (US\$ million)

\begin{tabular}{|l|r|r|r|}
\hline & Commitments & Disbursements & $\begin{array}{c}\text { Percent } \\
\text { Disbursed } \\
\text { (\%) }\end{array}$ \\
Agriculture & 30.0 & 8.6 & 28.5 \\
Education & 87.0 & 86.2 & 99.1 \\
Environment & 5.0 & 3.8 & 76.9 \\
Public Sector Management & 59.4 & 12.1 & 20.3 \\
Sanitation & 50.8 & 0.0 & 0.0 \\
Science and Techonology & 25.0 & 0.0 & 0.0 \\
Social Investment & 403.3 & 219.0 & 54.3 \\
Transportation & 510.0 & 203.0 & 39.8 \\
Urban Development & 60.0 & 18.6 & 31.1 \\
Grand Total & $\mathbf{1 , 2 3 0 . 5}$ & $\mathbf{5 5 1 . 3}$ & $\mathbf{4 4 . 8}$ \\
\hline
\end{tabular}




\section{AnNeX 4. Peru: Statistical Issues}

Macroeconomic statistics are broadly adequate for policy formulation, surveillance, and program monitoring. Peru has been in observance of the Special Data Dissemination Standard (SDDS) since August 1996 and meets the specifications for coverage, periodicity, and timeliness of the data categories. An advance release calendar and the metadata for Peru are posted on the Fund's Dissemination Standards Bulletin Board. A data ROSC was prepared and published in 2003.

Despite progress in recent years, there is scope for improvement in the following areas:

(i) coordination among the agencies that compile official statistics to avoid duplication of efforts and confusion among users; (ii) implementing a new benchmark and base year for GDP;

(iii) expanding the coverage of the wholesale price index to include mining, oil and gas extraction, electricity and water, public transportation, and communication; (iv) finalizing the migration to the standardized report forms for monetary data, with the introduction of report forms for other depository corporations and other financial corporations; and (v) expanding the scope of data sources for compiling financial flows of individual residents.

\section{Real Sector and Prices}

The authorities published a revised GDP series in 2000. The series used the 1994 benchmark estimates as the base year, and included input-output tables. However, due to limited availability of periodic source data, estimates after 1994 are largely based on extrapolation techniques. The lack of current detailed tables for supply and use hampers the reconciliation of discrepancies. As a result, changes in inventories are mainly determined as a residual. Although the quarterly accounts have benefited from some improvements in the timeliness of monthly production indices, coverage is still very limited. The National Statistics Office (INEI) is working on a new national account series using 2001 as the base year.

The weight structure for the CPI is derived from a 1993-94 household expenditure survey. Except for weights, source data are timely and consistent with the technical requirements for producing the index. The coverage of owner-occupied housing, however, was eliminated from the Metropolitan Lima index through the exclusion of imputed rent, a deviation from international practices. Imputed rent is included in the indices of the other 24 cities in the CPI. Thus, the national index is a weighted average of indices that have different coverage. The weights for the WPI are also outdated. INEI derived the weights from the 1994 input-output table and other reports and publications of relevant ministries. The statistical techniques used to compile the WPI follow generally accepted international standards.

The authorities monitor labor market developments using four indicators: open unemployment, underemployment, employment, and remunerations. The quality of the indicators has improved over recent years. However, wage data come with a relatively long delay; the nationwide unemployment and underemployment situation is surveyed only once a year; and labor productivity data are published only at the time of adjustments to electricity and telecommunications tariffs. 


\section{Fiscal Sector}

The government finance statistics (GFS) for the general government are compiled using the analytical framework of the GFS Manual 1986. For the consolidated central government, revenues are compiled on a cash basis, while expenditures are compiled on an accrual basis. The authorities have sent to the Fund information on the components of consolidated central government expenditures by function. The coverage of published national budget data is narrower than the fiscal statistics prepared for program purposes. The authorities have recently prepared a plan to migrate to the GFS Manual 2001, but the schedule for migration has yet to be defined. The authorities report annual GFS data using the GFSM 2001 analytical framework for publication in the Government Finance Statistics Yearbook (GFSY) and monthly data for the International Financial Statistics (IFS).

\section{Monetary Sector}

The BCRP prepares and publishes the analytical accounts of the banking system and of the central bank broadly in line with the methodology recommended by the Fund's Monetary and Financial Statistics Manual. The main discrepancy is the valuation of some financial instruments at cost rather than at market prices. Until early-2003, nonbank deposit-taking institutions were excluded in the depository corporations survey, but following the recommendations of the 2003 data ROSC mission, the BCRP began incorporating them. Monetary statistics are disseminated only in a summary form. At the request of the authorities, in January 2007 a mission visited the country to assist with the migration to the new standardized report forms. The mission finalized the report form for the central bank, recommending improvements in the classification and sectorization of some accounts. A follow-up mission, planned for FY 2008, should complete the work with standardized data for other depository corporations and other financial corporations.

\section{External Sector}

The BCRP prepares quarterly data on the balance of payments and international investment position largely in line with the recommendations of the fifth edition of the Balance of Payments Manual (BPM5). Data are reported to the Fund for publication in the IFS and the Balance of Payments Statistics Yearbook. Some departures from BPM5 include the lack of coverage of assets held abroad and land acquisition abroad by residents; lack of separate identification of liabilities to affiliated enterprises; and the recording of some external debt transactions that are not on an accrual basis.

The BCRP has been reporting since August 2001 weekly data on international reserves in accordance with the Operational Guidelines for Data Template on International Reserves and Foreign Currency Liquidity. Since August 2006, the BCRP is including the full amount of the liquidity requirements in the reserve template both under official reserve assets and as a contingent net drain (as specified in Section III of the Data Template). Peru disseminates quarterly data on external debt with a one-quarter lag in the BCRP website with a hyperlink to the Fund's website. External debt data are not fully compiled on an accrual basis, which contrast with the recommendations of the BPM5 and the External Debt Statistics: Guide for Compilers and Users. 


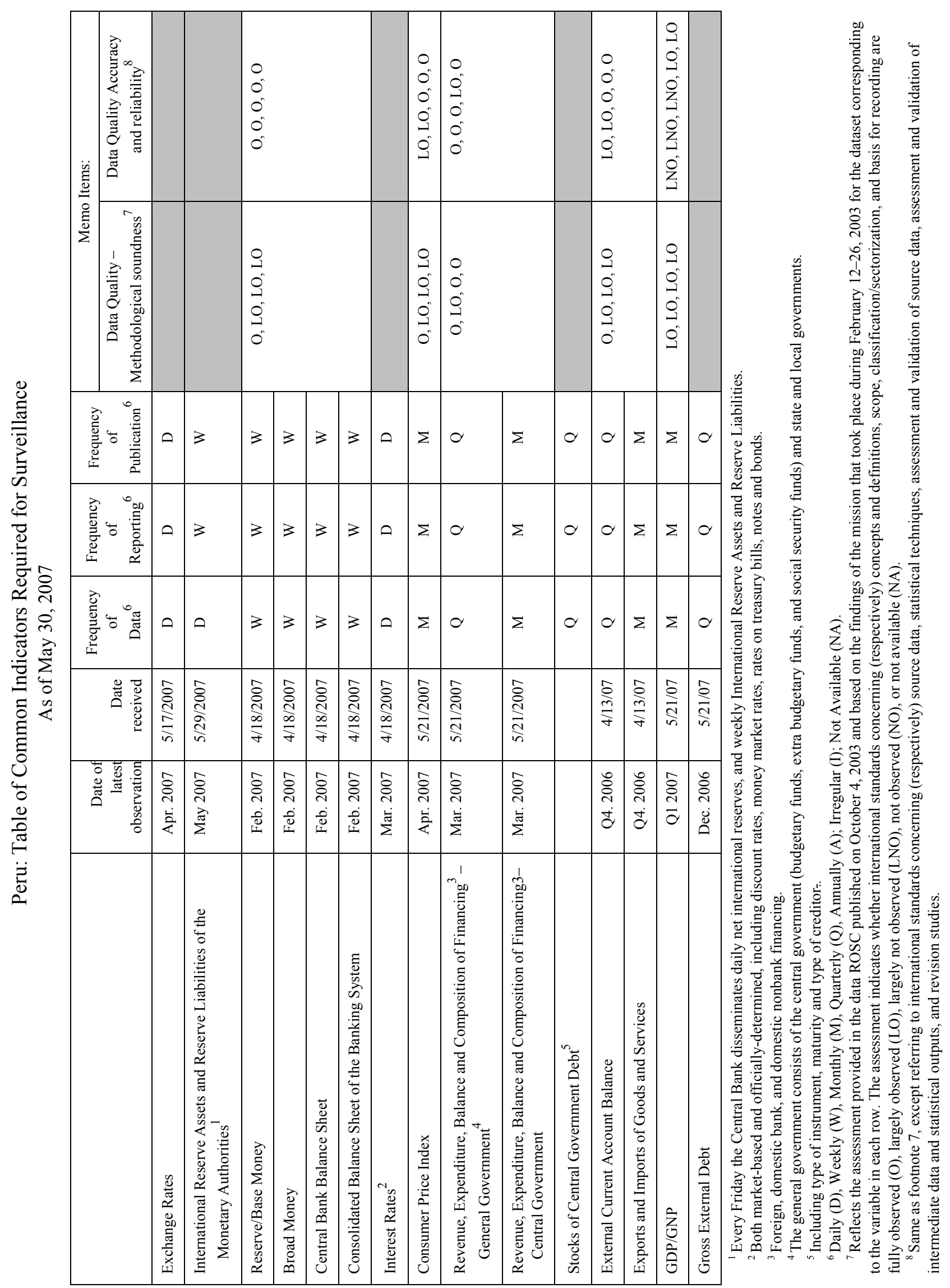


Lima, Peru

June 12, 2007

Mr. Rodrigo de Rato

Managing Director

International Monetary Fund

Washington, DC 20431

Dear Mr. de Rato,

1. This letter updates our letter of January 3, 2007, which presented the policies of our economic program supported by a Stand-By Arrangement (SBA), approved by the Fund's Executive Board on January 26, 2007. This letter reiterates our commitment to advancing reforms that will help reinforce the basis for high and sustained growth and decisively tackle high poverty levels. It also informs you of performance and policy intentions in 2007.

2. The Fund-supported program is off to an excellent start and is enabling Peru to continue benefiting from a formidable economic performance. Led by private investment and consumption, output and employment growth have remained strong and we now expect the economy to expand by about 7 percent during 2007. Inflation has remained quiescent and the Central Bank has aligned the inflation target more closely with average inflation rates in Peru and its major trading partners, by reducing the target to 2 percent, while keeping the tolerance band at \pm 1 percent. The external position is envisaged to remain strong, although the current account surplus would narrow to just 1 percent of GDP and net international reserves are projected to reach a level above $\$ 20$ billion (equivalent to almost 75 percent of total liquidity) by end-2007. All quantitative performance criteria for end-March were observed (Table 1) and we are proposing that the September 30, 2007 and December 31, 2007 indicative targets be set as performance criteria in accordance with the attached table 1, which are the same as in our letter of January 3, 2007. A revision of the structural benchmarks for 2007 is presented in table 2. All definitions and understandings specified in the January 3, 2007 Technical Memorandum of Understanding remain the same and apply to the performance criteria.

3. The Government believes that the policies set forth in this letter are adequate to achieve the objectives of its program, but it will take any further measures that may become appropriate for this purpose. Peru will consult with the Fund on the adoption of these measures, and in advance of revisions to the policies contained in the MEFP, in accordance with the Fund's policies on such consultation.

\section{A. Fiscal Issues}

4. Fiscal prudence has been pivotal in underpinning the strong economic performance. The consolidated public sector posted an overall surplus of 2.2 percent of GDP in 2006, above earlier expectations and mostly reflecting strong revenue and lower-than-expected 
expenditure execution at all levels of government. In 2007, we will continue addressing pressing social and infrastructure needs while preserving prudent fiscal targets under the program. To this end, we have issued two supplementary budgets, and have begun to implement reforms to the Government Procurement System (CONSUCODE), in consultation with multilateral institutions, and to the National Public Investment System (SNIP). An urgency decree has also been issued that simplifies and expedites approval procedures for public bidding and investment projects for all levels of government until end-2007. All these efforts will help ensure that much needed public investment at all levels of government takes place. Against this backdrop and with economic growth and commodity prices stronger than envisaged last year, we expect to meet the adjusted deficit of 0.5 percent of GDP for the consolidated public sector, as envisaged under the program. Despite our efforts to accelerate budget execution, the consolidated public sector could be close to balance in 2007, in light of potentially higher revenues.

5. We expect Congress to amend the Fiscal Responsibility and Transparency Law (FRTL) in the next few months to create room for infrastructure spending and to entrench fiscal discipline. Legislation has been approved by which the current 3-percent limit on the real growth of general government's expenditure will be applicable to the central government and exclude investment expenditure, as well as transfers. At the same time, we are evaluating the possibility of better aligning the new limit on current expenditure with the economy's increased productive potential and social needs. To preserve the transparency and quality of expenditure under the new rule, work is underway to modernize the budget classification system.

6. Further, we have continued to simplify and enhance the effectiveness of the tax regime. The tax code has been reformed to strengthen taxpayers' rights by removing the capitalization of interest on outstanding tax obligations and by extending participation in the simplified tax regime. A timetable for reducing the financial transactions tax (FTT) and the tax on net assets (ITAN) has been set: indeed, the FTT rate has been reduced, effective January 1, 2008 (end-December 2007 benchmark). As part of SUNAT's (the tax administration agency) medium-term strategy, indicators are being developed to monitor performance, including for VAT compliance, and tax audits will be more focused on massive and selective audits. Audit procedures are being simplified and we will improve the coordination between domestic taxes and customs obligations in the municipality of Lima and other large cities.

7. The new framework rationalizing tax exemptions is a major step forward in broadening the tax base. New tax exemptions will be allowed for six years and be subject to a technical assessment, which could extend them for three more years. In addition, all ministries are now required to present an assessment of existing tax exemptions to congress by April 2009 , at which date a decision will be taken on whether to eliminate or bring them into the new framework. The Ministry of Finance will issue regulations by end-June 2007 outlining the criteria to be followed in preparing such assessments. In addition, a new framework for 
tax exemptions on indirect taxes has been enacted for the Selva region (except Loreto), that will gradually replace such exemptions with direct transfers for infrastructure and social expenditure. Regulations to limit the adverse impact on tax collections in the free economic zone of Puno were issued in April.

8. The government is implementing several reforms to improve the quality of public spending:

- A high-level commission has been established to restructure the SNIP to expedite project viability approval while ensuring a high-quality of spending. In addition, to support the decentralization of the SNIP and assist SNGs, six regional offices have been established, and nine more are expected to be opened before year-end. We intend to allocate significant resources to boost the capacity of regional offices, with support from the IADB; and we also intend to involve the private sector to continue to assist SNGs in strengthening their capacity during the second half of 2007. Ensuring adequate monitoring of project selection, viability, prioritization, and ex-post evaluations by the MEF remain important priorities.

- With the assistance of an FAD resident advisor, full implementation of the central government TSA is envisaged for December 2007 (structural benchmark). The independent assessment of the government's Integrated Financial Management System (SIAF) will be available by end-September 2007. In consultation with the World Bank, UNDP and IADB, the government is reforming government procurement procedures, and a new law will be presented to congress in June. In the meantime, alternative mechanisms have been introduced to expedite procedures, in line with those in other countries in the region.

- A new unit to monitor the operations of SNGs is now operating at MEF (end-March benchmark). We have also taken steps towards establishing a subnational debt registry and recording the compliance of fiscal rules by SNGs by year-end. SNGs' capacities in fiscal management will continue to be strengthened. In line with our plan to complete the devolution of 82 functions and 153 responsibilities by end-2007, resources needed by SNGs to execute these functions and responsibilities are being quantified and will be transferred accordingly, upon satisfactory compliance with the established accreditation system.

9. Work towards introducing a permanent and comprehensive framework for PPPs has been initiated. A new methodology for valuing contingent liabilities of the public sector in relation to PPP projects has been finalized, and application guidelines will soon be developed. We have also begun to coordinate the work towards preparing a legal framework for PPP projects, which we now expect to submit to congress by September 2007. We will continue to limit the use of CRPAOs to already signed PPP projects in light of the fiscal risks they entail, and are looking into alternative financing instruments to facilitate PPP operations that provide a better risk sharing between the government and the private sector. 


\section{B. Poverty Alleviation}

10. In line with the government's objective of alleviating poverty, the Interministerial Committee for Social Affairs (CIAS) has completed a wide-ranging assessment of the existing social assistance programs (SAPs), and published an action plan to strengthen their effectiveness (end-March benchmark). Implementation of this plan has already started, as 82 SAPs were merged into 26 in May. In an effort to ensure adequate integration of SAPs into the 2008 budget, the government will adopt institutional and operational arrangements in the second half of 2007. Priority will be given to providing the CIAS with a permanent head and technical staff (end-September structural benchmark). This would ensure the implementation of a uniform targeting methodology across SAPs.

11. The efforts at rationalizing social programs will be assisted by the development of a Single Beneficiary Registry and a Household Targeting System (SISFOH), which we expect to have in place within the next few months. These systems should help to systematically reduce leakages across SAPs. We will also continue to strengthen the effectiveness and focus of the program Juntos, in consultation with the World Bank, with the number of participating families expected to rise from 170,000 as of end-2006 to 350,000 by end-2007. Following the new criteria for reorganizing programs, we are also launching a pilot program in the Huánuco Region, to tackle malnutrition with a multi-sector approach, financed with resources from the Fondo para la Igualdad, and intend to replicate it across 631 districts starting in 2008 . This pilot program will also incorporate our first efforts to implement performance budgeting of social programs, which we aim to expand to all public spending over the medium term. As part of our action plan, we will aim to prepare a comprehensive evaluation of universal social programs in the second half of 2007 in order to improve the quality and coverage of public education and health care.

\section{Financial Sector Issues}

12. To strengthen the coordination of lending practices by public financial institutions, representatives of COFIDE, Banco de la Nacion and Agrobanco have held meetings to determine which financial institutions qualify, according to strict financial criteria, to enter into lending and infrastructure-support agreements with Banco de la Nacion. As an important step towards strengthening the oversight of public financial institutions, Banco de la Nacion, Agrobanco, and MiVivienda will be fully incorporated under the regulatory and supervisory framework of the Superintendency of Banks, and our expectation is that congress will approve such amendment in the next few months. Technical work on the legal and regulatory framework for empowering the central bank to oversee and regulate the entire payments system continues.

13. To support the dedollarization process, the guarantees and the provision of the "good payer bonus" on mortgages in foreign currency are being discontinued to ensure that by endJune most new mortgage loans guaranteed by MiVivienda are denominated in Nuevo Soles (end-June structural benchmark). New lending programs in domestic currency, such as $M i$ 
Hogar and Techo Propio have been initiated to assist lower income groups. We are also finalizing technical discussions with private banks to exchange part of MiVivienda's foreign currency portfolio into Nuevo Soles. We also intend to securitize the rest of MiVivienda's foreign currency portfolio before end-2007.

14. The tax treatment of certificates of deposit, repurchase agreements, financial derivatives, and other financial instruments has been clarified (end-March structural benchmark). However, the clarification of the tax treatment of securitized transactions has been more complex than originally foreseen and we now intend to complete it, with technical assistance from the Fund, before end-December 2007. Also, the limit on pension funds' investments abroad has been raised to 15 percent, and cross-limits have been eased.

15. We continue to conduct debt management operations to improve its profile and extend the yield curve to provide a deep and liquid benchmark. We have recently reached agreement toward a prepayment of part of our nonconcessional obligations with the Paris Club due in 2007-2015 and remain engaged in resolving the issue of some disputed claims that have arisen in this context.

\section{Other Growth-Enhancing Reforms}

16. We remain committed to increasing the openness of the economy. We have recently reduced the average tariff level from 10 percent to 8.3 percent and are evaluating the possibility of additional measures to foster competitiveness. Further steps have been taken to improve the business environment. One-stop windows for importers and exporters and microenterprises are expected to be fully operational by year-end. We are extending the capacity of commercial courts in Lima and remain committed to establishing commercial courts in Trujillo and Arequipa by end-2007.

17. In light of the strong performance under the program and the important progress being made in growth enhancing reforms, we hereby request the completion of the First Review under the Stand-By Arrangement.

Sincerely yours,

$\frac{\text { Luis Carranza }}{\text { Minister of Economy and Finance }}$

Luis Carranza

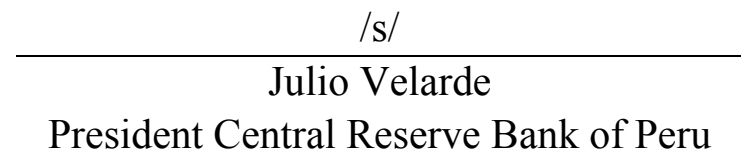


Table 1. Peru: Quantitative Performance Criteria and Inflation Consultation Mechanism for 2007

\begin{tabular}{|c|c|c|c|c|}
\hline & \multicolumn{3}{|c|}{ Program } & \multirow[b]{2}{*}{ Dec. 31} \\
\hline & Mar. 31 & Jun. 30 & Sept. 30 & \\
\hline \multicolumn{5}{|c|}{ (Cumulative amounts from December 31,2006 , millions of New Soles) } \\
\hline \multicolumn{5}{|c|}{ Borrowing requirement of the combined public sector } \\
\hline Unadjusted limits $1 / 2 / 3 / 4 /$ & $-1,396$ & $-4,190$ & $-2,761$ & 2,418 \\
\hline Adjusted limits & $-1,646$ & & & \\
\hline
\end{tabular}

(Cumulative amounts from December 31, 2006, millions of U.S. dollars)

Net international reserves of the Central Reserve Bank,

excluding foreign-currency deposits of financial institutions

Unadjusted targets $5 / 6$ /

Adjusted targets

Actua

Margin

\begin{tabular}{|c|c|c|c|}
\hline-260 & 44 & 336 & 350 \\
\hline $\begin{array}{r}-635 \\
948\end{array}$ & & & \\
\hline 948 & & & \\
\hline
\end{tabular}

Outstanding short-term external debt of the nonfinancial

public sector

Limits

Actual

Margin

Contracting or guaranteeing of nonconcessional public debt with maturity of at least one year

Unadjusted limits 7/ 8/ 9/

Adjusted limits

Actual

Margin

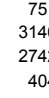

Of which: external debt of 1-5 year maturity

Limits

Actual

751
3146
2742
404

Margin

100

External payments arrears of the public sector (on a continuous basis)

Limits

Actual

NPV of future government payments associated with PPP

operations (on a continuous basis)

Unadjusted Limits 10/

Actual

Margin

(Consultation bands for the 12-month rate of inflation, in percent) 11/

\begin{tabular}{|c|c|c|c|c|}
\hline Outer band (upper limit) & 5.5 & 5.5 & 5.5 & 5.5 \\
\hline Central point & 2.5 & 2.5 & 2.5 & 2.5 \\
\hline Inner band (lower limit) & 0.5 & 0.5 & 0.5 & 0.5 \\
\hline Outer band (lower limit) & -0.5 & -0.5 & -0.5 & -0.5 \\
\hline Actual & 0.3 & $\ldots$ & $\ldots$ & $\ldots$ \\
\hline
\end{tabular}

Sources: Staff estimations.

1/ PIPP proceeds are included below the line.

2/ The limit on the borrowing requirement of the combined public sector will be adjusted downwards by the amount central government revenues net of mandatory transfers exceed program estimates of S/. 10,489 million at end-March, up to a ceiling of S/. 250 million; S/. 23,359 million at end-June, up to a ceiling of S/. 500 million; S/. 32, 807 million at end-September, up to a ceiling of S/. 750 million; and S/. 44,821 million at end-December, up to a total ceiling of S/. 1,000 million

$3 /$ The limit on the borrowing requirement of the combined public sector will be adjusted for the operating balance of the BCRP.

$4 /$ The limit on the borrowing requirement of the combined public sector will be adjusted upward by up to US $\$ 100$ million for capital spending by Petroperu, over the $\$ 30$ million already included in the program.

5/ The target for net international reserves will be adjusted upward by the amount by which net foreign borrowing of the nonfinancial public sector exceeds '-US $\$ 15$ million at end-March, -US $\$ 138$ million at end-June, -US\$274 million at end-September, and -US\$148 million at end-December 2007. It will be adjusted downward for shortfalls from programmed

net foreign borrowing. The amounts in excess will be deposited at the BCRP.
$6 /$ The target for net international reserves will be adjusted downward for withdrawals for portfolio management purposes of deposits held at the Central Reserve Bank by the Consolidated Pension Reserve Fund (FCR) and any other funds managed by the ONP. This downward adjustment will not exceed US $\$ 300$ million at any time in 2007.

Consolidated Pension Reserve Fund (FCR) and any other funds managed by the ONP. This downward adjustment will not exceed US $\$ 300$ million at any
$7 /$ The limit will be adjusted upward by any amount of debt issued, and used in, debt-exchange operations, or for prefinancing of government operations.

8/ The current debt limits do not include contracting of non-guaranteed debt by Petroperu and will be adjusted upward by up to US $\$ 300$ million for debt contracted by Petroperu during 2007

9/ The limit on contracting and guaranteeing of nonconcessional public debt will be adjusted upwards for guarantees contracted or extended by the government in relation to concessions, up to a ceiling of US $\$ 430$ million for the year as a whole.

10/ Discount rates to calculate the NPV of the future stream of payments will be the currency-specific commercial interest reference rates (CIRRs) published by the OECD and specified in the TMU.

11/ Should inflation fall outside the inner band, the authorities will discuss with the Fund staff the appropriate policy response. Should inflation fall outside the outer band, the authorities will also complete a consultation with the Executive Board of the Fund on the proposed policy response before requesting further purchases under the arrangement. 
Table 2. Peru: Structural Measures for 2007

\section{Structural Benchmarks}

June 30

Ensure that most of new mortgage loans extended by banks with the guarantee of MiVivienda are denominated in nuevo soles

\section{September 30}

Submit to congress a legal framework for PPP operations

Appoint a new head of CIAS and technical staff

\section{December 31}

Clarify the tax treatment of securitized transactions

Full implementation of the Treasury Single Account (TSA) for the central government

2008 Budget prepared according to the modernized budget classification system and incorporated into the charts of accounts

Issue new regulations regarding new risk categories and provisions to address foreign currency risk. 


\section{Statement by the IMF Staff Representative}

June 27, 2007

1. This statement provides additional information that has become available since the circulation of the staff report. It does not alter the thrust of the staff appraisal.

\section{Recent indicators suggest that macroeconomic performance remains strong:}

- Real GDP is estimated to have grown by about $7 \frac{1}{2}$ percent on average during the first four months of 2007. Recent surveys show business and consumer confidence still at record-high levels and expectations of further improvement in economic conditions.

- The external current account posted a surplus of 2.8 percent of GDP as of end-2006, some 0.2 percent of GDP larger than previously estimated. Appreciation pressures on the Nuevo Sol have subsided in recent weeks, partly reflecting strong import growth. While there has been limited intervention by the central bank in the foreign exchange market, net international reserves have reached US\$21.7 billion (close to 180 percent of foreign currency deposits) as of mid-June. Financial market conditions remain favorable, with Peru's sovereign bond spread declining to a record-low of around 100 basis points.

\section{Progress on structural reforms has been mixed:}

- The rationalization of social assistance programs is progressing, with the government issuing decrees to initiate their consolidation.

- $\quad$ The end-June structural benchmark on ensuring that most new mortgage loans extended by banks with the guarantees of MiVivienda are denominated in local currency is expected to be missed. The authorities explained that commercial banks have requested an extension for discontinuing such guarantees for foreign currency mortgage loans. MiVivienda has now established a timetable for fully discontinuing the issuance of such guarantees by January 1, 2008. The staff is of the view that this delay will not compromise achieving the program's objectives.

- $\quad$ Congress recently passed a law allowing the public bank Agrobanco to begin accepting deposits and expand its direct lending, while lessening its regulatory oversight. The authorities have strongly opposed this measure and President Garcia has stated his intention to veto the most controversial aspects of this law. In addition, consumer loans by Banco de la Nación have risen by about 40 percent (y/y) in May. The authorities noted that a significant part of the rise was related to payroll-linked loans to public sector employees, with limited credit risk. In the staff's view, increased presence in the financial system by public banks could crowd-out the activities of private institutions and potentially entail fiscal costs over the medium term. 
Press Release No. 07/145

International Monetary Fund

FOR IMMEDIATE RELEASE

Washington, D.C. 20431 USA

June 27, 2007

\section{IMF Executive Board Completes First Review under Peru's Stand-By Arrangement}

The Executive Board of the International Monetary Fund (IMF) today completed the first review of Peru's economic performance under a 25-month Stand-By Arrangement in the amount equivalent to SDR 172.4 million (about US\$261 million).

The authorities have indicated that they are treating the arrangement as precautionary. The arrangement was approved on January 26, 2007 (see Press Release No. 07/15).

Following the Executive Board discussion, Mr. Murilo Portugal, Deputy Managing Director and Acting Chair, said:

"Over the past several years, Peru has benefited from record high and broad-based economic growth, a strong external position, low inflation, and declining vulnerabilities, owing to the implementation of sound macroeconomic policies and a favorable external environment. Continued commitment to sound policies and structural reforms will be crucial to entrench economic growth, strengthen the economy's resilience to shocks, and alleviate poverty.

“The authorities' strategy to improve the targeting and effectiveness of social assistance programs will help intensify their poverty alleviation efforts, which should be based on a broad consensus. The authorities intend to buttress the capacity of the Interministerial Committee for Social Assistance to ensure that the strategy is well coordinated and implemented in a timely manner.

"Sound fiscal policies to underpin stability remain the backbone of the program, which aims to address critical social and infrastructure needs by ensuring high-quality public spending. The restructuring of the National System of Public Investment will expedite approval of public investment projects while protecting their quality. Measures are being taken to bolster the capacity of subnational governments to evaluate and execute projects, including with private sector support. Prompt establishment of a comprehensive legal framework for publicprivate partnerships will help ensure that public investment remains of high quality, and that there is an equitable sharing of risks between the public and private sectors. 
"In amending the Fiscal Responsibility and Transparency Law, the authorities' intention to introduce strict sanctions for noncompliance with the Law's fiscal goals is welcome. To support fiscal prudence, a unit has been established in the Ministry of Finance to monitor subnational governments' compliance with the Law, and efforts will be made to ensure that the devolution of fiscal functions to subnational governments preserves effective accreditation mechanisms and fiscal prudence.

"Tax incentives have been rationalized, certain regional exemptions have been replaced with budgetary transfers, and a timetable has been set to reduce distortionary taxes. It is important to resist pressures to grant new exemptions. Tax administration will be strengthened, building on recent gains.

"Monetary policy has been prudent. The new inflation target should further entrench price stability and help reduce dollarization. In light of the comfortable level of official reserves and the increased resilience of the banking system to exchange rate shocks, some greater exchange rate flexibility should be possible, to promote awareness of currency risks and further develop the domestic financial markets.

"Financial sector reforms have helped reduce the risks associated with financial system dollarization, but further measures are needed to reduce the dollarization of mortgage loans. Envisaged legislation to strengthen regulatory oversight of public financial institutions is welcome, and there is a need to ensure that public banks do not undermine financial sector competition," Mr. Portugal said. 


\section{Statement by Javier Silva-Ruete, Executive Director for Peru}

June 27, 2007

1. The Peruvian economy continues to perform well, supported by sound macroeconomic policies and a favorable international environment. Work on poverty alleviation and structural reform geared to achieve sustainable and equitable growth - a priority under the program - is proceeding with determination. All end-March performance criteria were met. In view of the progress under the Stand-By Arrangement, the authorities request completion of the First Review. They consent to the publication of the staff report.

2. Led by non-primary sectors linked to domestic demand, GDP growth reached 8 percent in 2006 and is forecasted at around 7 percent in 2007. Investment, consumption, and employment are expanding steadily thanks to solid market confidence. The external position remains sound, with international reserves equal to 3.7 times short-term debt (residual basis) and 77 percent of total liquidity as of the end of the first quarter.

3. In 2006, the consolidated public sector posted a surplus of 2.1 percent of GDP, due to strong revenue performance and lower-than-expected expenditure execution. In 2007, the priorities on the fiscal front are: to continue to address pressing social needs and bridge the significant infrastructure gap; to implement plans to improve the quality of expenditure; and to strengthen the tax system. In this regard:

- The authorities intend to move ahead with budget execution at all government levels, especially for much-needed public investment. Legislation has been issued to expedite public bidding and approval of investment projects; and efforts continue to decentralize the National System of Public Investment and enhance sub-national capacities with the Inter-American Development Bank's (IADB) support and private sector involvement. The authorities thus expect to meet the adjusted fiscal deficit of 0.5 percent of GDP for 2007, as envisaged under the program, although they recognize that it could be close to balance, in light of potentially higher revenues. To further press ahead with the government's ambitious investment program, an amendment to the Fiscal Responsibility and Transparency Law has been proposed whereby the current 3-percent limit on the real growth of general government's expenditure would be applicable only to central government consumption expenditure.

- At the same time, the authorities are committed to safeguarding the transparency and quality of expenditure. In particular, ensuring adequate selection and monitoring of investment projects is at the top of the agenda. Furthermore, the budget classification is being modernized, and implementation of the central government's Treasury Single Account is envisaged for December 2007. The independent assessment of the government's Integrated Financial Management System (SIAF) will be available by 
end-September 2007. In consultation with the World Bank, the United Nations Development Plan (UNDP) and the IADB, the government is reforming government procurement procedures. Follow-up of sub-national government operations essential to underpin the decentralization process - continues to be reinforced. Measures in this field include the establishment of a new monitoring unit for subnational governments at the Ministry of Economy and Finance (already functioning). Work on a legal framework for PPP operations is underway, and submission to Congress is now expected for end-September. Furthermore, a recently developed methodology to estimate contingent obligations associated with PPP projects has been published.

- $\quad$ Revenues continue to be buoyant thanks to strong growth and still positive external conditions. In addition, the authorities persist in their efforts to strengthen the tax system. Steps are being taken to further simplify the tax structure - especially by reducing distortionary taxes_-; and administrative improvements continue to be introduced, especially for auditing procedures. Notably, the recent passage of legislation providing a strict timeframe for tax exemptions is a major step towards broadening the tax base. In this context, existing exemptions will be assessed to decide whether to eliminate or bring them into the new framework.

4. In order to further diminish exposure to foreign currency-denominated public debt and extend the yield curve, the authorities recently reached an agreement to prepay part of Peru's commercial obligations with the Paris Club due in 2007-2015. As a result of active debt-management policies, fiscal discipline, and high economic activity, the public debt burden is expected to diminish from 32.6 percent of GDP in 2006 to around 24 percent of GDP by 2010.

5. Inflation has remained subdued, and in February the authorities reduced the inflation target from 2.5 per cent to 2 percent to align it more closely with average inflation rates in Peru's main trade partners and help to entrench de-dollarization, while keeping the tolerance band at \pm 1 percent. Towards the end of 2006, twelve-month inflation dropped below the previous target range due to supply shocks, and continued to decline during the first four months of the year. However, this trend started to reverse in May, as temporary factors have begun to recede, and 12-month inflation is expected to converge towards the 2 percent target over the remainder of the year. In the longer run, economic drive is expected to remain consistent with the target range as productivity continues to improve across sectors. Also, the authorities commit to continue limiting interventions in the foreign exchange market to those needed to confront excessive exchange rate volatility or abrupt fluctuations, without an explicit or implicit commitment to any given exchange rate level.

6. As a matter of priority, the authorities continue their plans to promote rapid poverty alleviation. The Interministerial Committee for Social Affairs (CIAS) completed an assessment of existing social assistance programs (SAPs) and published an action plan. In 
line with it, the authorities recently consolidated 82 SAPs into 26 and will adopt institutional and operational arrangements to increase their effectiveness - i.e., providing the CIAS with sound technical staff and implementing a consistent targeting methodology. Focus and coverage of the conditional cash transfer program Juntos will be further improved with World Bank assistance. In line with policy priorities, conditionality under this program will focus on the prevention of children malnutrition. Resolute steps are being taken to upgrade education standards: after successfully completing an evaluation of teachers in January, the authorities are setting out to improve their capabilities through continuous training. The quality and coverage of public health care is also being given due priority.

7. In May, Peru secured U.S. Congress support for a free-trade agreement (FTA), pending amendments to include labor and environmental standards. The FTA with the U.S., Peru's main trading partner, will further encourage export growth and diversification, increase employment, catalyze structural reform, and facilitate investment flows.

8. On the financial sector:

- The financial system continues to strengthen. Financial intermediation is expanding, and regulation and supervision are constantly being reinforced - including through adequate provisioning against currency risks - to preserve resilience. As part of the authorities' de-dollarization strategy, work is proceeding to shift MiVivienda's (the state-sponsored housing program) portfolio to domestic currency and ensure that new mortgage loans are likewise denominated. Additionally, new lending programs in domestic currency have been launched. Importantly, to ensure asset quality, the authorities expect, in the next months, congressional approval of legislation that will bring Banco de la Nación (the government's financial agent), Agrobanco (the state agricultural development bank), and MiVivienda under supervision by the Superintendency of Banks.

- In addition: (i) work on the legal and regulatory and supervisory framework for enabling the central bank to oversee the payments system continues; (ii) due to technical complexities, the clarification of the tax treatment of securitized transactions is now expected to be completed before end-December; and (iii) the limit on pension funds' investments abroad has been raised to 15 percent to improve profitability and facilitate risk diversification.

9. The authorities stand ready to take the necessary steps to meet their commitments under the program and pledge to maintain the usual close dialogue with the Fund. 